University of Nebraska - Lincoln

DigitalCommons@University of Nebraska-Lincoln

10-18-2019

\title{
The Dragonflies and Damselflies of Nebraska
}

Fred Sibley

fcsibley@empacc.net

Janis Paseka

paseka76@gmail.com

Roy Beckemeyer

royb@southwind.net

Follow this and additional works at: https://digitalcommons.unl.edu/zeabook

Part of the Entomology Commons, Environmental Sciences Commons, and the Terrestrial and Aquatic Ecology Commons

\section{Recommended Citation}

Sibley, Fred; Paseka, Janis; and Beckemeyer, Roy, "The Dragonflies and Damselflies of Nebraska" (2019). Zea E-Books. 78.

https://digitalcommons.unl.edu/zeabook/78

This Book is brought to you for free and open access by the Zea E-Books at DigitalCommons@University of Nebraska - Lincoln. It has been accepted for inclusion in Zea E-Books by an authorized administrator of DigitalCommons@University of Nebraska - Lincoln. 


\section{THE DRAGONFLIES AND DAMSELFLIES OF NEBRASKA}

Fred Sibley, Janis Paseka, Roy Beckemeyer 



\section{THE DRAGONFLIES \\ AND DAMSELFLIES \\ OF NEBRASKA}

Fred Sibley, Janis Paseka, Roy Beckemeyer

*

Zea Books

Lincoln, Nebraska

2019 
Copyright $\odot 2019$ Fred Sibley, Janis Paseka, Roy Beckemeyer. All rights reserved.

ISBN: 978-1-60962-161-2

doi: 10.32873/unl.dc.zea.10904

Zea Books are published by the University of Nebraska-Lincoln Libraries

Electronic (pdf) edition available online at https://digitalcommons.unl.edu/zeabook/

Print edition available from

http://www.lulu.com/spotlight/unllib

UNL does not discriminate based upon any protected status. Please go to http://www.unl.edu/equity/notice-nondiscrimination

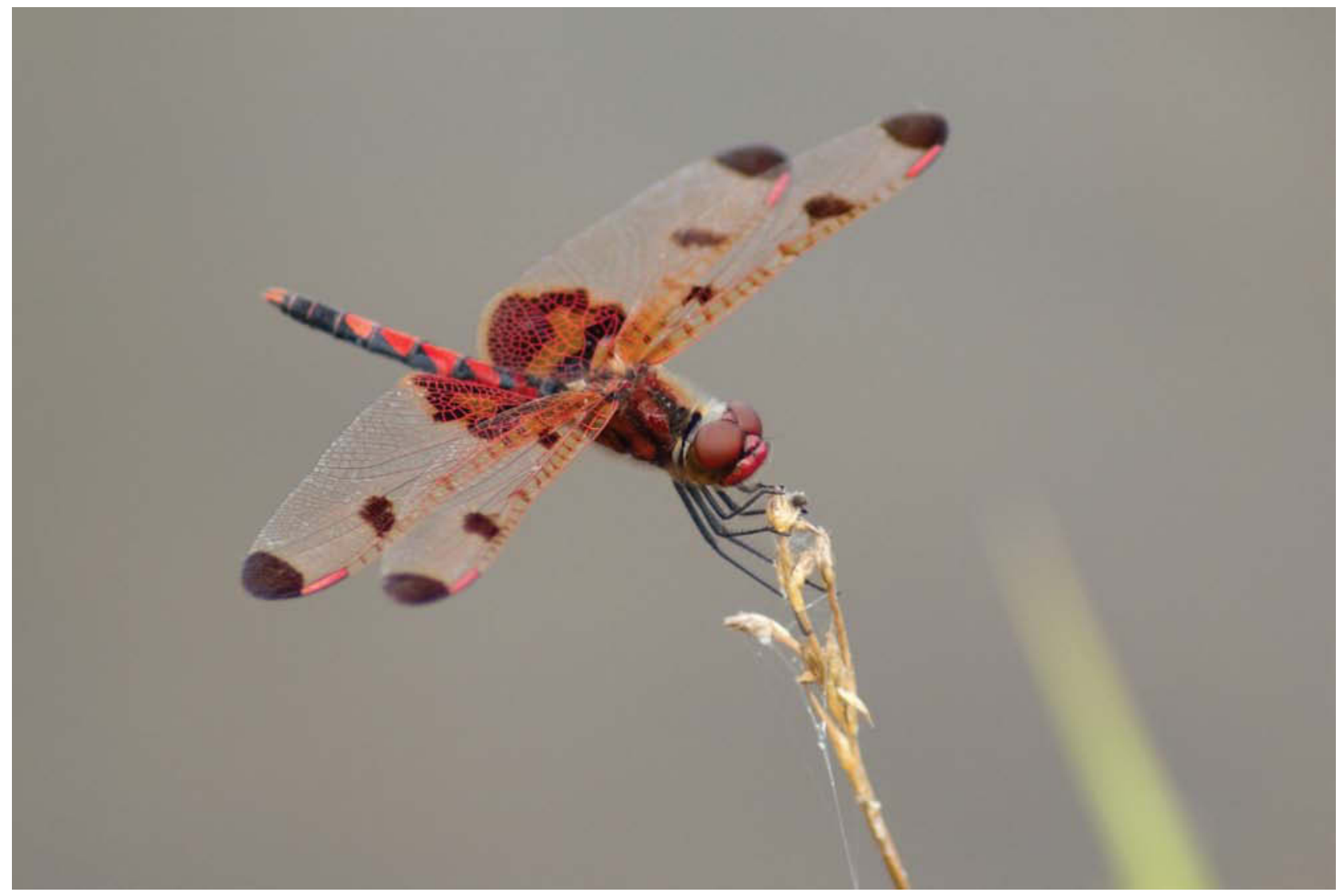

\section{Nebraska \\ Lincoln}




\section{THE DRAGONFLIES AND DAMSELFLIES}

\section{OF NEBRASKA}

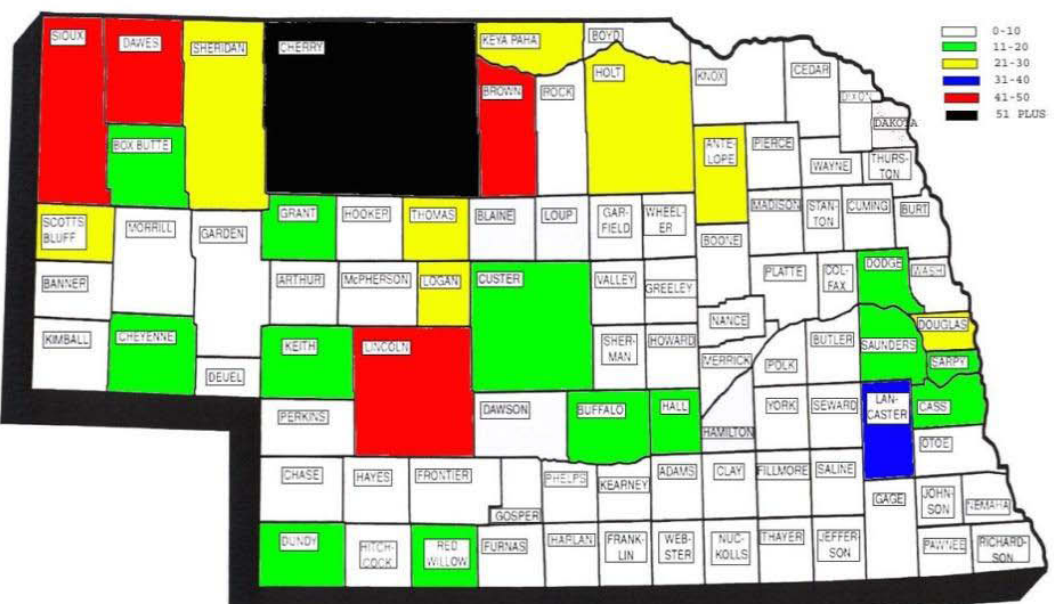

MAP 1 NEBRASKA COUNTY RECORDS 2004

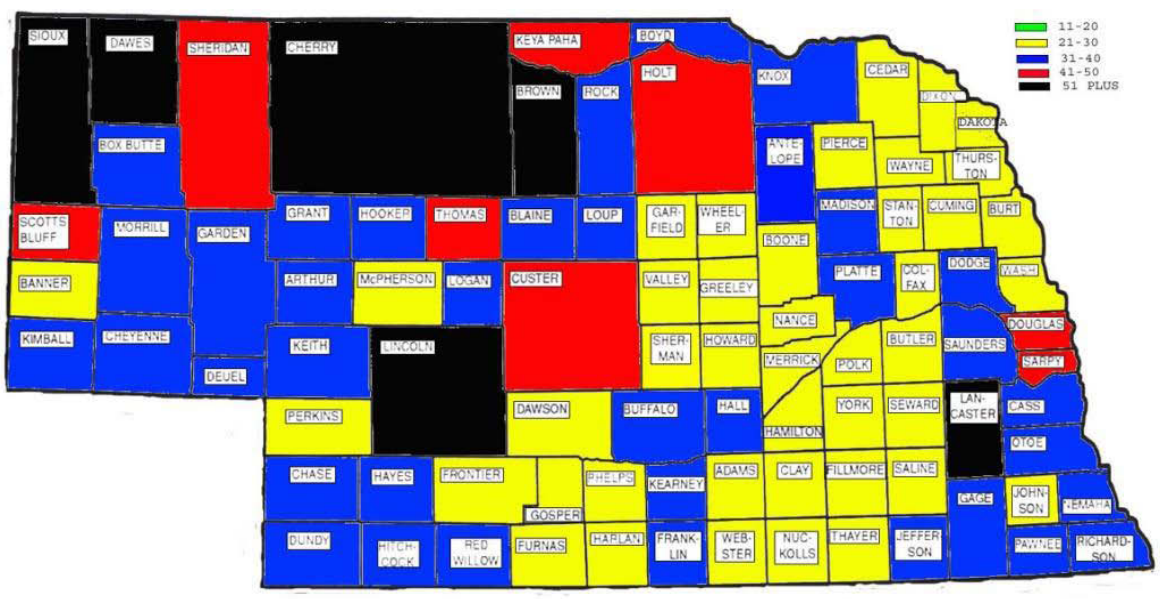

MAP 2 NEBRASKA COUNTY RECORDS 2017

Fred Sibley, Janis Paseka, Roy Beckemeyer

New York, Nebraska, Kansas 2019 
Oct. 15, 2019

\section{FOREWORD}

This is a final draft copy of a paper on Odonates of Nebraska. This manuscript will almost certainly join the considerable list of unpublished material on the Odonates of Nebraska.

The authors are sending this draft copy to a rather small group of people who have been connected to the 2005-2014 survey or who might otherwise be interested in the manuscript, so we would encourage you to share this with anyone else you think would be interested.

Basically the senior author has run out of time and perhaps interest for further editing of the manuscript. The data is already dated (started in 2015 and based on a study started in 2005) and will be more useful if available now. We are always interested in comments and additions, but there is unlikely to be a revised version of the document. Updates on additional county records may appear periodically in Argia.

This is a baseline for future studies and a number of appendices have been added for the more serious reader or Appendix $\mathrm{G}$ mainly for the future reader. In writing the paper I was constantly thinking of what would have been of use to me when I started the study in 2005 and the appendices represent this thinking.

If you are collecting in Nebraska there should be useful information in Appendix A on the various Game \& Parks regions. Appendix B provides the full background on species attributed to Nebraska we consider misidentification. Appendix $C$ provides extra detail on the history of identification \& re-identification of earlier records of Lestes australis and $L$. disjunctus in Nebraska. Appendix D provides a quick reference guide to a species' biogeographic assignment and increase in county records from 2004 to 2017. Appendix E breaks down county records from each county on their biogeographic origin. Appendix $\mathrm{G}$ is a list of population, area and human density for each county.

The authors have used the term "Dot Map" and "Dmap" on the maps and in discussion. These are always reference to Donnelly $(2004 a, b, c)$. These maps were the baseline this study started from and are still the best quick reference for North American distribution. 


\section{TABLE OF CONTENTS}

2 Authors

Abstract

3 Introduction

4 Map 1: Nebraska County Records 2004 (color coded) Map 2: Nebraska County Records 2017 (color coded)

5 Nebraska for Odonatologists Map 3: Annual Precipitation Isolines

6 Map 4: Game and Parks Regions

9 Map 5: River Systems of Nebraska

10 Limitations of Study

12 Map 6: Nebraska County Records 2004 (numbers) Map 7: Nebraska County Records 2017 (numbers)

13 Short History of Odonate Collecting in Nebraska

17 Biogeography

Table A: Average Number of Species in each N-S Band 18

Table B: Number of Species in each N-S Band 19

Table C: Percentage of Game and Parks Regions' County Records by Biogeo. Group 19

Table D: Number of County Records per Game and Parks Region by Biogeo. Group 22

Table E: Number of Species per Game and Parks Region by Biogeographic Group 22

23 Species Accounts - Identifying Dragonflies and Damselflies

24 Nebraska Odonates: Zygoptera (Damselflies)

Zygoptera: Calopterygidae (Broad-winged Damsels) 24

Zygoptera: Lestidae (Spreadwings) 26

Zygoptera: Coenagrionidae (Pond Damsels) 29

44 Nebraska Odonates: Anisoptera (Dragonflies)

Anisoptera: Aeshnidae (Darners) 44

Anisoptera: Gomphidae (Clubtails) 49

Anisoptera: Macromiidae (River Cruisers) 55

Anisoptera: Corduliidae (Emeralds) 56

Anisoptera: Libelluidae (Pond Dragonflies) 59

71 Acknowledgements

72 References

74 Appendix A: Game and Parks Regions

81 Appendix B: Species Erroneously Reported from Nebraska

83 Appendix C: Lestes australis/disjunctus

84 Appendix D: Dot Map Records without Documentation

86 Appendix E: Biogeographic Assignment of Species

89 Appendix F: County Records by County and Biogeographic Origin

92 Appendix G: County Areas and Population Densities 


\title{
THE DRAGONFLIES AND DAMSELFLIES OF NEBRASKA
}

Fred Sibley

2325 Co. Rd. 6, Alpine, NY 14805 fcsibley@empacc.net

Janis Paseka

1585 Co. Rd. 14 Blvd., Ames NE 68621 paseka76@gmail.com

Roy Beckemeyer

957 Perry Ave., Wichita, KS 67203 royb@southwind.net

\section{AUTHORS}

Roy Beckemeyer started the work on odonates of Nebraska in the 1980s, organized the 1998 DSA meeting in Valentine and published numerous notes and one bulletin on Nebraska and the region. He was an important mentor to the other authors, who were both introduced to serious odonate study at the 1998 DSA meeting or shortly thereafter.

Janis Paseka and her husband Don added dragonfly recording to their frequent birding trips and Janis started and still maintains a website for Nebraska records (http://unsm-

ento.unl.edu/Odonata/index.html). Her contributions to making the manuscript readable and accurate have been incredibly varied and called on her knowledge as an editor and long-time resident of Nebraska. She was the major contributor to the sight identification tips in the species accounts.

Fred Sibley wrote most of the original draft of this paper and he and his wife Margaret (Peggy) spent over 300 days in Nebraska between 2005 and 2014 doing the field work reported on here.

\begin{abstract}
Nebraska had been very poorly surveyed prior to 2005 and 63 counties had fewer than 10 records. By 2017 the number of county records had nearly quadrupled, to over 3000 records, the average county total had increased from 9 to 33 and all counties had at least 21 records. An effort was made to collect data more or less uniformly from all 93 Nebraska counties. The areas with intense corn and soybean farming, eastern and southcentral areas, are low in diversity (2130 species per county), the southeast and western half of the state are higher (31-40 species) and the northwestern and northern Sandhill counties are the richest with more than 50 species per county. The present state list of 109 species represents 12 additions since 1998 . Eleven
\end{abstract}


additional species have been reported from the state, but are considered invalid or have been re-identified. This paper presents a short history of odonate study in Nebraska and an analysis of the data for the 109 species recorded in Nebraska to date. These species are primarily Eastern (37) or species common in the east but transcontinental in distribution (40). The Midwestern species (11) and Western species (17) account for only $16 \%$ of the county records. At the lowa/Nebraska border and more markedly at the Nebraska/Wyoming border, there is an obvious drop-off in eastern species. Eastern species are common to the middle of the state and then drop off gradually to the Wyoming border and very sharply in Wyoming. Transcontinental species (28) going north of Nebraska show a marked Midwestern gap with some species present in western lowa and western Nebraska with no records in between. The much smaller number of Transcontinental Southern species (12) include 7 of the 10 commonest species in the state. They show no Midwestern gap but drop off precipitously at the Wyoming border. The 17 western species drop off quickly east of the Panhandle at about the 101st parallel.

\section{RESUMEN}

En Nebraska, muy pocos estudios se habían hecho hasta el año 2005. De 63 condados se tenían menos de 10 registros. Para el 2017, el número de registros por condado casi se habían cuadruplicado a más de 3000, el promedio total por condado había aumentado de 9 a 33 y todos los condados tenían al menos 21 registros. Se hizo un esfuerzo para recopilar datos de una manera más o menos uniforme en los 93 condados de Nebraska. Las áreas con intenso cultivo de maíz y soya, las áreas del este y centro sur, son bajas en diversidad (21-30 especies por condado), la parte sureste y la oeste del estado son más altas (31-40 especies), y los condados del noroeste y norte de Sandhill son las más ricas con más de 50 especies por condado. La lista actual del estado de Nebraska con 109 especies presenta 12 adiciones desde 1998. Además, se habían reportado once especies adicionales en el estado, pero se consideran inválidas o se han vuelto a identificar. Este artículo presenta una breve historia del estudio de Odonata en Nebraska y un análisis de los datos de las 109 especies registradas en Nebraska hasta la fecha. Estas especies son principalmente de la región este (37) o comunes en el este pero de distribución transcontinental (40). Las especies del medio oeste (11) y las especies del oeste (17) representan solo el $16 \%$ de los registros del condado. En la frontera de lowa / Nebraska y más marcadamente en la frontera de Nebraska / Wyoming, hay una evidente caída en el número de especies del este. Las especies orientales son comunes en la mitad del estado y luego su número se reduce gradualmente en la frontera de Wyoming y de forma muy marcada en Wyoming. Las especies transcontinentales (28) hacia el norte de Nebraska muestran una marcada brecha en el medio oeste con algunas especies presentes en el oeste de lowa y en el oeste de Nebraska, y sin registros entre los dos. El número mucho menor de especies transcontinentales del sur (12) incluye 7 de las 10 especies más comunes del estado. No muestran una brecha en el medio oeste, pero su número declina precipitadamente en la frontera de Wyoming. Las 17 especies del oeste declinan rápidamente al este de la faja de terreno o lo llamado como "Panhandle" cerca del paralelo 101. 


\section{INTRODUCTION}

In 2005 Nebraska was one of the least-studied states for odonate distribution. Dennis Paulson (2003) had published a map of the US showing two-thirds of Nebraska's 93 counties had fewer than 10 species records. Thomas Donnelly (2004a, b, c) published his dot maps for the US and Canada, and the paucity of records from Nebraska was even more evident, showing an average

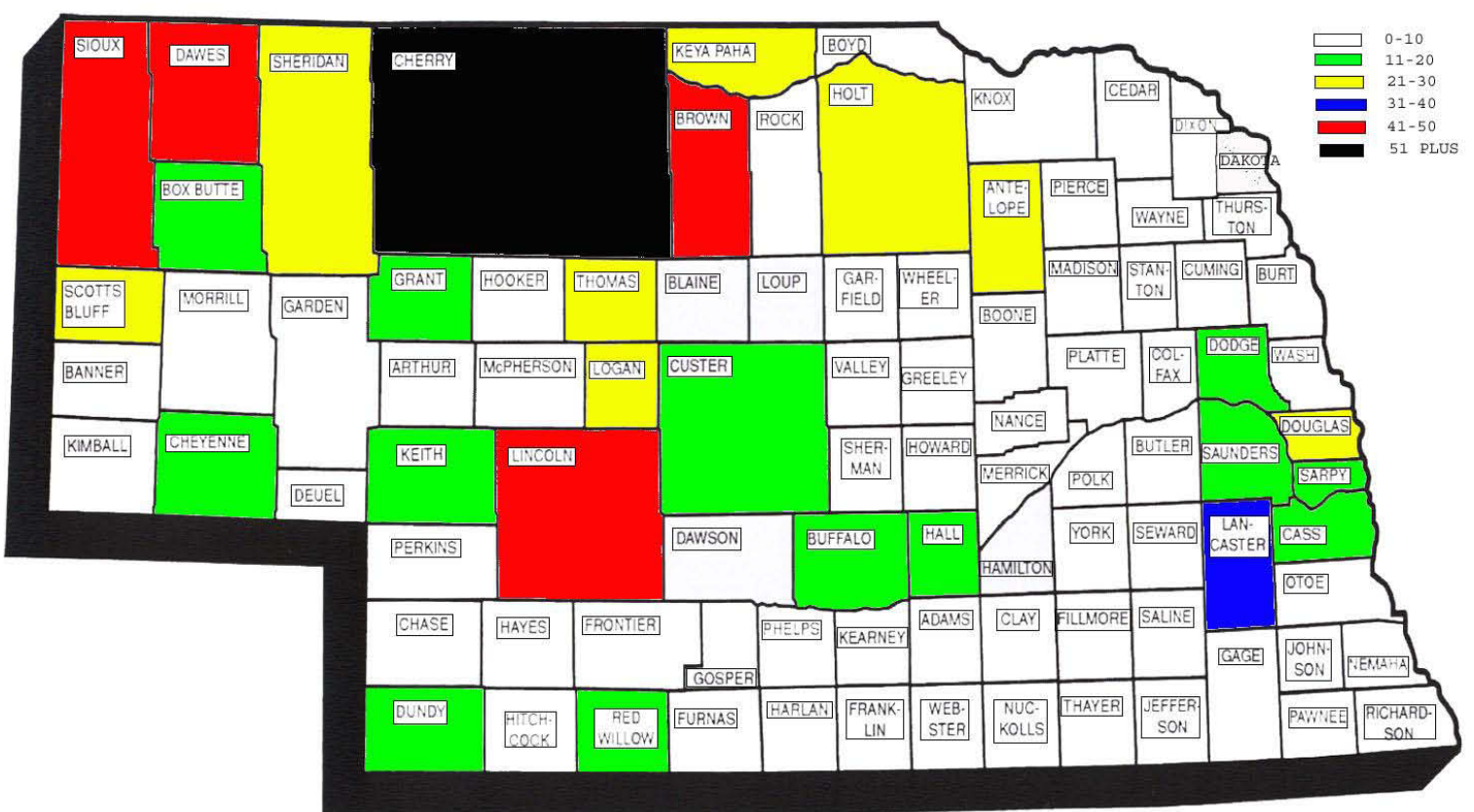

MAP 1 NEBRASKA COUNTY RECORDS 2004

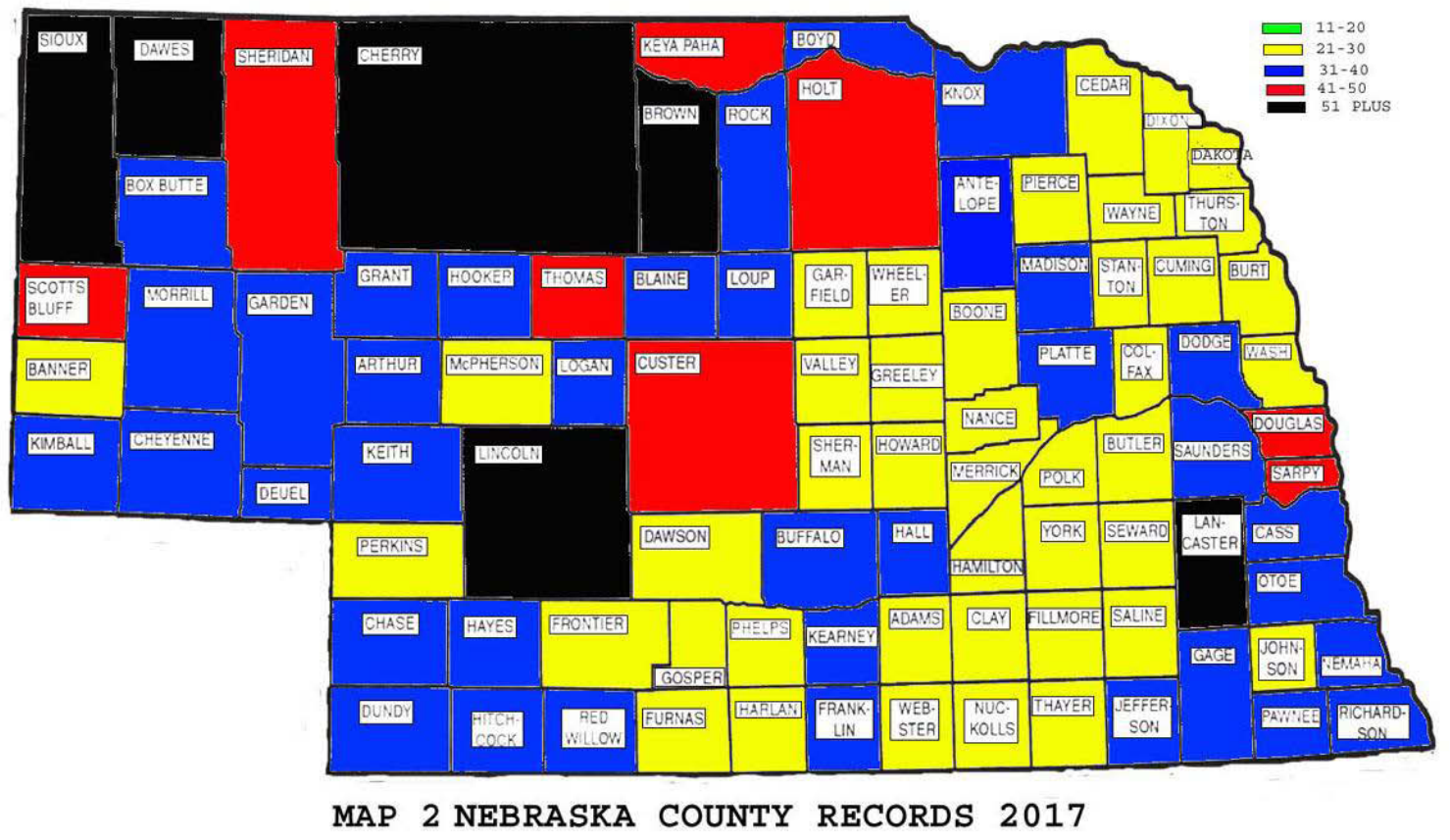

of 9 species per county. As a very new odonate collector (44 US species and 40 foreign species), Fred attended the 1998 DSA meeting in Valentine (Cherry County), Nebraska, where he was 
overwhelmed by the numbers of odonates and where he met Roy Beckemeyer, one of the meeting's organizers and a leading expert on Nebraska odonates. Fred had previously spent a number of summers in Nebraska in the 1950s and 1970s as part of a study on hybridization between eastern and western birds. Having enjoyed those summers in Nebraska, and thinking eastern and western odonates might present similarly interesting hybridization problems, he and Peggy planned a 2005 summer trip to sample counties with few or no odonate records. A month and 600 new county records later the hybrid populations had not materialized, but the study continued as one on odonate distribution in the state. One final year followed a previous final year until in 2014 it was determined enough was enough and the joy and excitement of exploring Nebraska was replaced by data analysis. The following is an attempt to analyze ten years of summer collecting trips, visits to various museums, plus all the work of other odonatologists. The cut-off date for new records was Dec. 2017.

\section{NEBRASKA FOR ODONATOLOGISTS}

Nebraska is a large state and originally mostly prairie. The Onion Atlas says 10,000 miles east to west, but it only seems that way on a hot summer day traveling west on 1-80. It is large. Larger, at some 77,000 square miles, than any state east of the Mississippi and $50 \%$ larger than New York state, but only slightly over 400 miles east to west and 200 north to south. Most people only know Nebraska from driving I-80 along the Platte River flood plain through endless miles of corn and soybeans. A poor introduction to the state, a state with a lot of history and innumerable beautiful areas where one can escape the rush of the modern world.

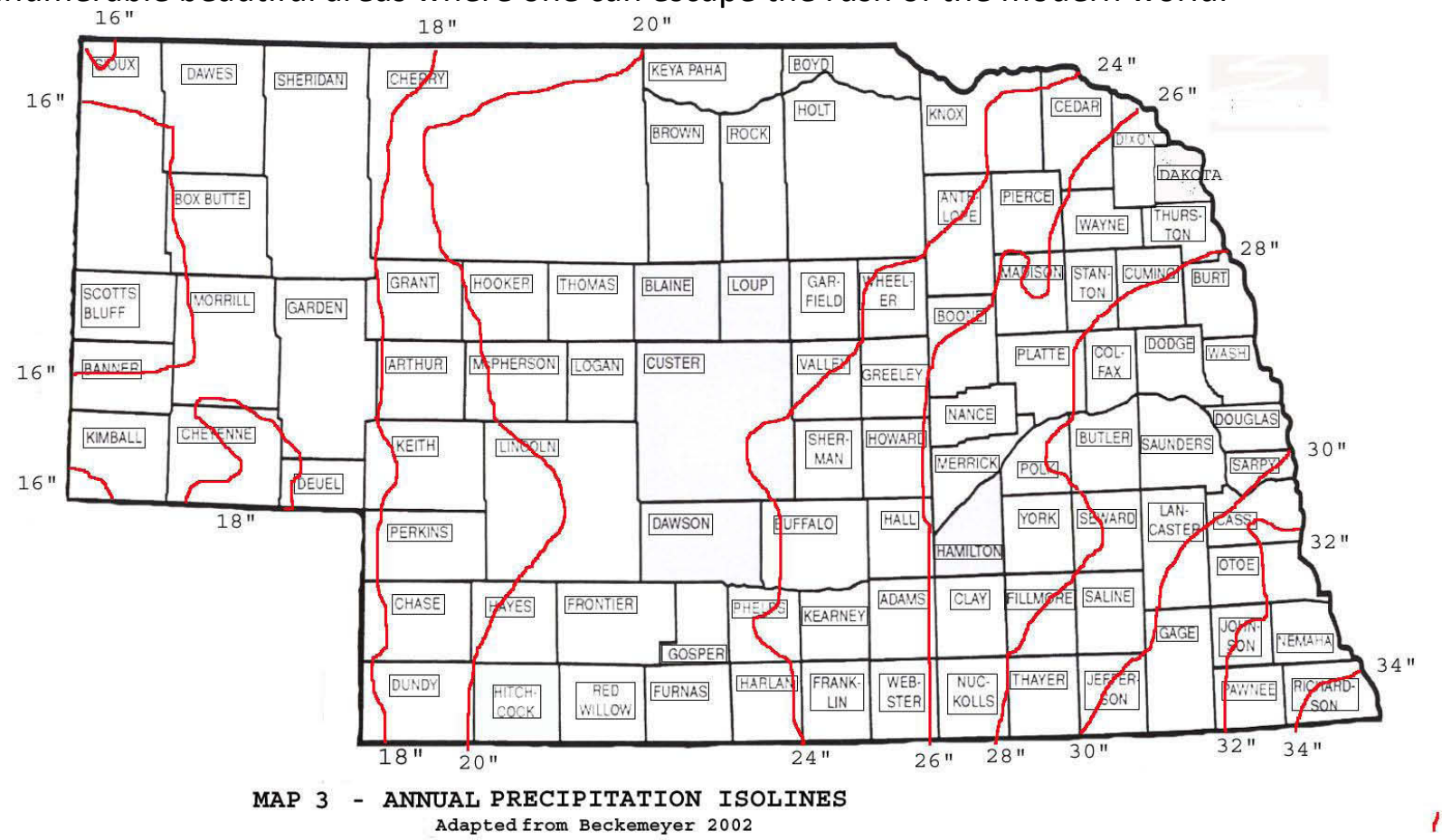

If you drive north or south out of the Platte River valley you find gently rolling hills in the east, the striking Sandhills, covering a quarter of the state in the north central area, the Rainwater Basin in the south central area (a major waterfowl migration site), while in the west and particularly northwest you find striking buttes, canyons and the Pine Ridge country. Nebraska 
was, 150 years ago, part of what was called the Great American Desert, and although almost certainly wetter now, it is still a dry climate. Rainfall is highest in May but only declines slowly to October. Rainfall declines and elevation increases from east to west and to lesser extent north to south. The SE corner, at 1000 feet, gets an average of 35 inches of rain a year and the NW corner, at 5000 feet, 15 inches (see Map 3). Rainfall declines about an inch per 25 miles. In addition, there are very marked wet and dry years when the rainfall is well below or well above the average. In 2011 the Missouri River was above flood stage at Omaha for over 100 days, but 2000-2007 was one of the state's periodic extended droughts.

Despite the large size of the state, the odonate habitat diversity is limited with permanent aquatic habitats being rare. "Stable" wetland habitat is uncommon and usually spring fed or associated with a river or reservoir. During drought years some of this "stable" habitat also dries out and may remain dry for a number of successive years. A truly permanent wetland area is rare and usually in a park, wildlife management area or nature center.

The state is split into six sections by the Game and Parks Commission: Northeast (NE), Southeast (SE), Sandhills (SA), Southcentral (SC), Panhandle (PA) and Southwest (SW). These boundaries have proved useful in this study and we have used them repeatedly in presenting data. (See map 3 for boundaries and counties included.)

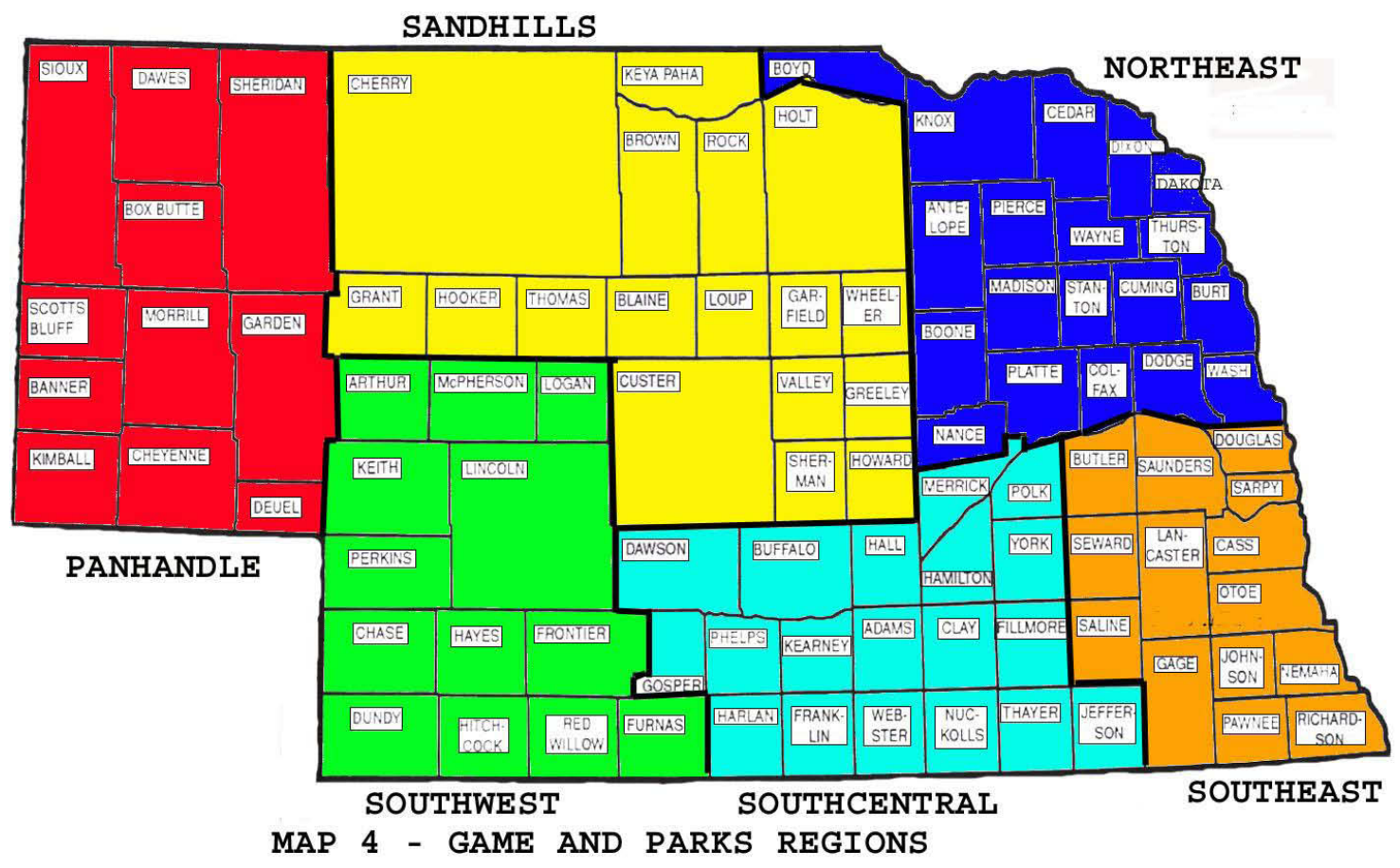

The Northeast and Southeast Regions bordering the Missouri River are the transition zone, a fairly short transition zone, between the greener and wetter agricultural fields of lowa and the increasingly drier and browner prairie habitat of Nebraska. Counties along the Missouri are more heavily wooded and have better odonate habitat than the next few rows of counties, and heavily farmed, increasingly drier croplands extend to the middle of the state. Nebraska is primarily an agricultural state with croplands dominating in the Northeast, Southeast, 
Southcentral Regions and river valleys in the other regions. These croplands are characterized by a road on almost every section line and the distinctive quarter section circles of central pivot irrigation.

Continuing west, the land away from the rivers becomes increasingly less suitable for planting crops, so grazing predominates in the Southwest, Panhandle and particularly in the Sandhill regions. Grazing areas have fewer roads, fewer people and are closer to the original habitat of the early 1800 s.

Agriculture, with its associated tillage, ditching, use of herbicides and pesticides, and irrigation, has eliminated most of the original prairie wetlands, while agricultural runoff and erosion have compromised the streams in these areas.

Nebraska is an agricultural state and $92 \%$ of the land, about 45 million acres, is evenly split between range and crops. Cattle are the major agricultural product with corn, 9.3 million acres, and soybeans, 5.1 million acres, being the top field crops. The number of trees has increased greatly over the last 100 years with organized planting (Arbor Day originated in Nebraska City in 1872) and fire control. Recent plantings of shelter belts have provided a new habitat for odonates, particularly in the Sandhills, and such areas are often excellent odonate sites, even at a great distance from water. In many areas fire control has resulted in an invasion of red cedar into former prairie areas.

Nebraska is not densely populated. Population figures for cities are from the 2015 Census Bureau estimates. County populations (see Appendix G) are from Census Bureau 2018 estimates. In general, rural counties are decreasing in population and counties with larger cities are increasing. Omaha with 447 thousand and Lincoln with 280 are the largest cities, and both are close to the eastern border of Nebraska. The $3^{\text {rd }}, 4^{\text {th }}$ and $5^{\text {th }}$ largest cities, all located along the Platte, are 54, 52 and 33 thousand in size. The average density for the state is 22.9 people per square mile with regional densities of 22.8 (NE), 151.0 (SE), 2.6 (SA), 22.9 (SC), 6.1 (PA), 6.2 (SW). See Appendix F for county totals and density. By contrast, the 29 rural western counties of New York State have an average density of 170 and only 3 New York counties (in the 6.1 million acre Adirondack State Park) have fewer than 30 people per square mile. People coming to the 1998 meeting through northern Nebraska left South Sioux City $(13,000)$ on highway 12 and in the next 230 miles didn't find a town with a population over 500 until getting to the big city of Valentine (pop. 2,800).

The Platte River Valley has always been the easy east-west way across the state. The Mormon Trail, railroad and I-80 followed the north bank and the California/Oregon Trails plus Pony Express were on the south side of river. The railroad, laid along the north bank in the 1860s, made all these trails obsolete and determined where the cities would be located.

Nebraska, as clearly shown in the absence of collecting over the years, is not a prime destination for odonate enthusiasts. There is probably no species one would come to Nebraska to find since there are no endemics, and all the habitats are better represented in surrounding states. 
An indication of the scarcity of good habitat is shown by the 55 less common species recorded from Nebraska. They make up less than $15 \%$ of the total county records; the commonest of these species is found in only 18 counties, 15 counties have none of the less common species, and 30 more counties have only one or two less common species.

Dam-created ponds and lakes are numerous and varied, ranging from cattle watering ponds on tiny runoff streams that go dry in the summer to Lake McConaughy (Big Mac), the largest reservoir lake in the state. Borrow pits, cattle watering ponds, and irrigation sumps are new features of the landscape and because of their abundance in the landscape are an important factor for odonate distribution, despite being less than ideal habitats. A limited number of these ponds are spring fed and can provide excellent permanent habitat, but most are seasonal with limited species diversity. Unfortunately, many of the original natural marshes, seasonal ponds and low wet areas have been drained in agricultural areas or vanished when the water table dropped due to excessing pumping of irrigation water. Cattle ponds and also water tanks with a windmill pumping water to them are often magnets for a few species of odonates, particularly as one goes west, where they can be the only water in large areas of prairie. Small, "eastern" style ponds with lots of edge vegetation and abundant aquatic growth are mostly in the eastern row of counties along the Missouri and drop off rapidly as one goes west. The western ponds of this nature are spring fed, rare, and oases for odonates. Borrow pits, where sand has been dug out for construction, are concentrated along the rivers or major highways, particularly 1-80. When these are abandoned, they fill with groundwater and may become part of state recreation areas, wildlife management areas or surrounded by homes of people who want to be on the water. Some become rather stagnant, oxygen-starved lakes, of use to only a few common species of odonates, but others that are aerated or have a natural flow of water through the sand are outstanding odonate sites. Irrigation sumps, a common feature in the irrigated landscape, are usually seasonal and important for a limited number of common species. In several areas, the irrigation run off may pool in low areas and provide a semipermanent habitat. In Morrill County, one such site was one of the most productive areas for that county. Secondary sewage treatment ponds are permanent features, usually posted "no trespassing", but, because of their permanence, are an important odonate habitat in some western counties and in many counties during drought years. The emerging odonates spread to the nearby fields so one does not have to trespass to benefit from these sites. Reservoirs are usually built for irrigation and, in most cases, also for flood control. The large fluctuations in water level make them almost sterile odonate sites. However, an increasing number are used primarily for wildlife or recreation - i.e. a more stable water level and chance for aquatics to establish. All the reservoirs have the potential of good to excellent odonate sites at seepage areas into the reservoir, exit streams below the dam, entry mashes of tributary streams, and nearby ponds supported by elevated ground water levels due to the reservoir. With numerous exceptions these sites are primarily used by the commoner and more adaptable species.

The rivers range from very large to ones where the upper reaches may be little more than a creek. The Missouri River forms the eastern and northeastern boundary of the state. The flood plain is mainly on the lowa side so much of the Nebraska frontage is characterized by low 
wooded bluffs dropping sharply to the river. One old oxbow lake on the lowa side of the river is part of Nebraska and another on the Nebraska side is part of lowa - both just north of Omaha. The Missouri is very muddy and during floods may drastically modify odonate habitat along the river. In 2011 the river was out of its banks for over 100 days and counts of river species the next two years were down. The Platte River, the signature river of the state, runs west to east across the center of the entire state and is wide, shallow and sandy with multiple sandbars. In

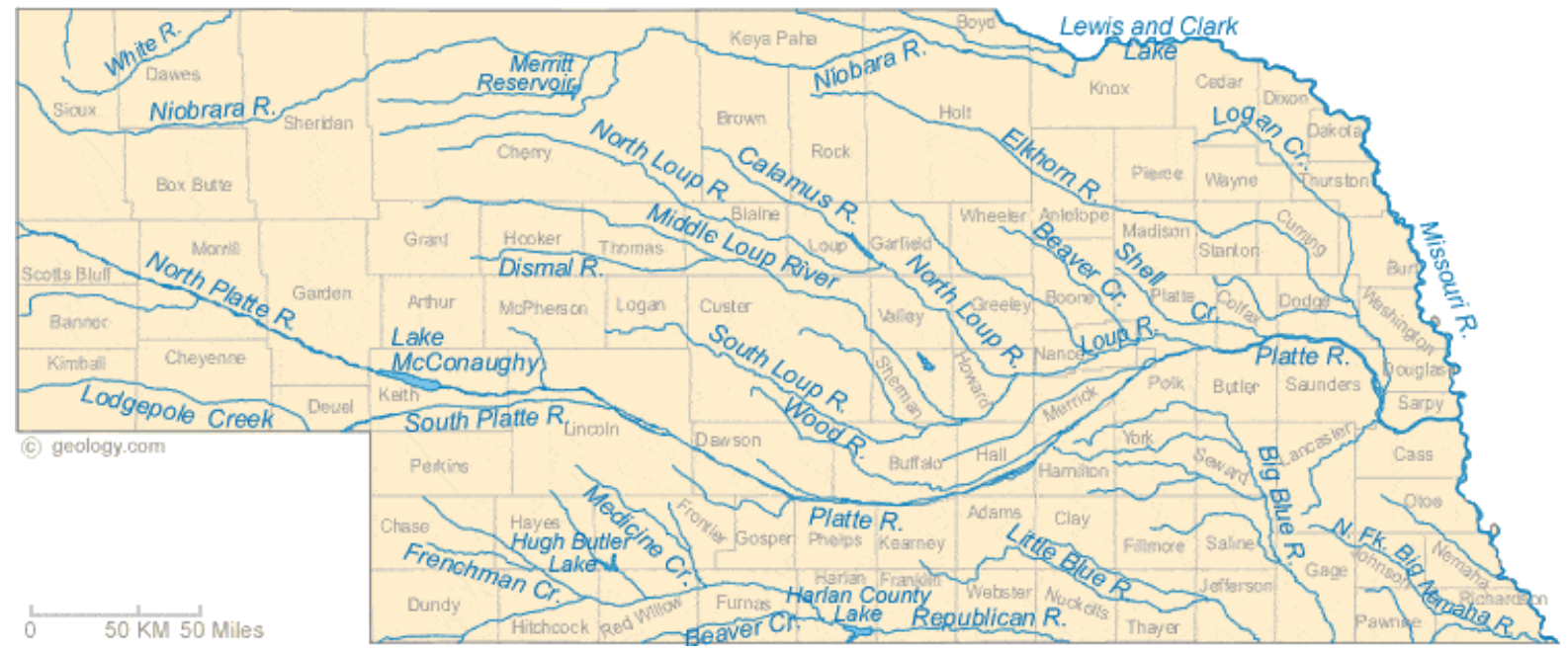

\section{Map 5 River Systems of Nebraska}

courtesy of the Nebraska Game and Parks Commission

the western third of the state it splits into the North and South Forks, going into Wyoming and Colorado respectively. The largest lake in the state, Lake McConaughy (Big Mac), is formed by a dam on the North Fork just north of Ogallala. The Republican River is another shallow sandy river similar to the Platte but much smaller. It originates in Colorado and runs along the southern border of Nebraska before turning south into Kansas about two-thirds of the way across Nebraska. Harlan County Reservoir, Swanson Reservoir, and Enders Reservoir are important sources of irrigation water, and the summer river flow is heavily impacted by irrigation withdrawal from these reservoirs. The Big and Little Blue Rivers drain the low lying area (Rainwater Basin) between the Platte and Republican from Kearney County in the west almost to Lancaster County with the river then running south to the Kansas border. This river is smaller, deeper and muddier than the Republican or Platte Rivers. The Nemaha River, just east of the Blue, is a small, shallow, sandy river with a watershed encompassing a handful of southeastern counties. Salt Creek runs northeast from the capital of Lincoln into the Platte and is the only significant tributary coming into the river from the south. To the north of the Platte River, two major tributaries, the Loup and Elkhorn Rivers, run mainly west to east and join the Platte southeast of Columbus and west of Gretna respectively. They originate in the Sandhills and, as a result, have a more even yearly flow of clearer and cooler water than the Platte, Blue, or Republican. The Niobrara River is totally a Nebraska river except for the tiny stream headwaters in eastern Wyoming. It runs along the northern edge of the state and joins the Missouri in Knox Co. This river, running through the Sandhills for most of its length, is clear, cool 
and often contained in pine/cedar lined hills. It is the most scenic river in Nebraska and the most popular river for canoeing and tubing, as well as being a famous site of fossilized Miocene mammals. Near its headwaters in Sheridan, Dawes and Sioux Counties it is little more than a small stream.

Stream habitat in the state varies from some excellent trout streams in the northwest (and one on the southern border) to the more typical farmland streams contained in a straight deep gully and carrying a heavy load of agricultural runoff. Irrigation runoff or irrigation releases into feeder streams may result in short alterations between full and dry stream beds and zero odonates. Some small streams in mid-summer are only a series of unconnected pools, while others will have short spring fed sections between dry sections. However, small shallow permanent streams, although uncommon, are widespread and more common on the southeast border.

The six regions used by the Game and Parks Commission are treated in more detail in Appendix A with an emphasis on individual counties and on collecting localities productive in 2005-2014. The state is doing an excellent job in adding or enhancing odonate habitat in the parks and wildlife management areas and any protected area tends to increase in ecological value.

\section{LIMITATIONS OF STUDY}

The lack of any meaningful baseline data prior to this study has made comparison of past data to present data almost meaningless. Questions of range expansion, increases in abundance and their relationship to changes in agriculture, population, etc., are just guesses.

The present study provides a baseline for 2005-2014, but a baseline with many qualifications. One of which is the rapidity with which the landscape and odonate fauna can change - the odonates of 2005 had already changed by 2014. The state is still thinly studied. The ten years of visits represent a little over 3 days for each of the 93 counties to cover the seasonal changes and the difference between dry and wet years. This gives an excellent coverage of common species, but seasonal, intermittent and uncommon species are less well represented. Any active field person interested in odonates and residing year round in a county will easily add county records to our lists.

Visits to the state from 2005 to 2014 have been concentrated between mid-June and mid-July with only a few visits later, so county list are likely to lack late season species like Archilestes grandis (Great Spreadwing) or ones more common in August and September like Aeshna constricta (Lance-tipped Darner) and Sympetrum costiferum (Saffron-winged Meadowhawk). The late afternoon Enallagma signatum (Orange Bluet) and the evening Enallagma vesperum (Vesper Bluet) were under-collected. Neurocordulia molesta (Smoky Shadowdragon), possibly widespread, was never collected. Collecting effort per county has been relatively uniform so the difference in county records between counties closely reflects real differences in diversity. The counties close to universities (Lancaster Co. [51/7], Lincoln Co. [61/9], Dawes Co. [60/11]); nature centers (Douglas Co. [47/7], Sarpy Co. [49/11]); or just pleasant and popular places to collect (Brown Co. [54/11], Cherry Co. [72/17], Sioux Co. [59/10]) have been visited multiple 
times and at many different seasons by other collectors and the species totals are not comparable to adjoining counties. [The numbers after the counties are the total species for that county followed by the number of the 55 less-common species. Zero to two less-common species are more normal for a county]. Map 6 and Map 7 show species totals for each county by actual number and Map 1 and Map 2 by color coding for 2004 and 2017, respectively.

Common species are often neglected in regional surveys and that has not been the case in this survey. Extra effort has been expended to find common species lacking in a county. Thus the white spaces in species distribution maps indicate true absence for the commonest 10-15 species or at least very limited occurrence. Hetaerina americana (American Rubyspot) is recorded from all but 4 counties in the state and repeated visits to these counties specifically to find that species have come up empty. It is impossible to rate and show abundance and many county records are based on only one sighting or specimen. If the species maps have a lot of white spaces, the species is probably uncommon. At the edge of its range, a species can be assumed to be uncommon. Comments in the species accounts address some of the abundance questions.

We have worked to visit good streams, ponds and marshes in each county and in some cases this means all wetland habitat in a county. In Banner County one small wildlife pond and the exit stream have provided 25 of the 30 county records. The difference between drought years and wet years can represent a several-fold increase in individuals and a 30 percent increase in species, particularly in western counties. In Perkins County we found 14 species (13 in a secondary sewage treatment pond), in the dry year of 2005. In the very wet year of 2010 this pond was little changed but only Plathemis lydia (Common Whitetail) was common and many species seen in 2005 must have moved to the better habitat provided by the rains. We not only found 9 additional species in the county, 5 in a pond flooding a road that was dry 2 years later, but a several hundred-fold increase in several common species: Enallagma civile (Familiar Bluet) was in the hundreds of replenished groundwater pools, Ischnura verticalis (Eastern Forktail), absent in 2005, was similarly widespread, Tramea onusta (Red Saddlebags), only one sight record in 2005, was everywhere. Amphiagrion intermediate (Red Damsel) was only found at a 30-40 foot stretch of seepage from a restaurant kitchen.

We have therefore visited each county at least once in a wet year and once in a dry year. Irruption species like Pantala (Rainpool Gliders), Tramea onusta (Red Saddlebags), or some Aeshna (Darners) may be present in a large number of counties in one year and sometimes for a short period in that year. Such species are therefore under collected, as it would take multiple collectors to visit all the counties in the short period these species are present. All county records have been vetted by Odonata Central and with only a few exceptions are represented by specimens or photos.

The 831 Dot Map records in Odonata Central (from Donnelly 2004a, b, c) do not have exact localities, dates or collector, and for the majority of the Nebraska Dot Map records it has been impossible to match records to those used by Donnelly. We therefore tried to support all Dot Map records with a museum specimen, old photo or recent record. The 3103 county records in 
Odonata Central used in this study represent 2170 in the IORI collection, 545 from the University of Nebraska State Museum, 163 from other museums, 183 from other collectors, and 42 Dot Map records (see appendix D). We have found no photos, museum specimens or

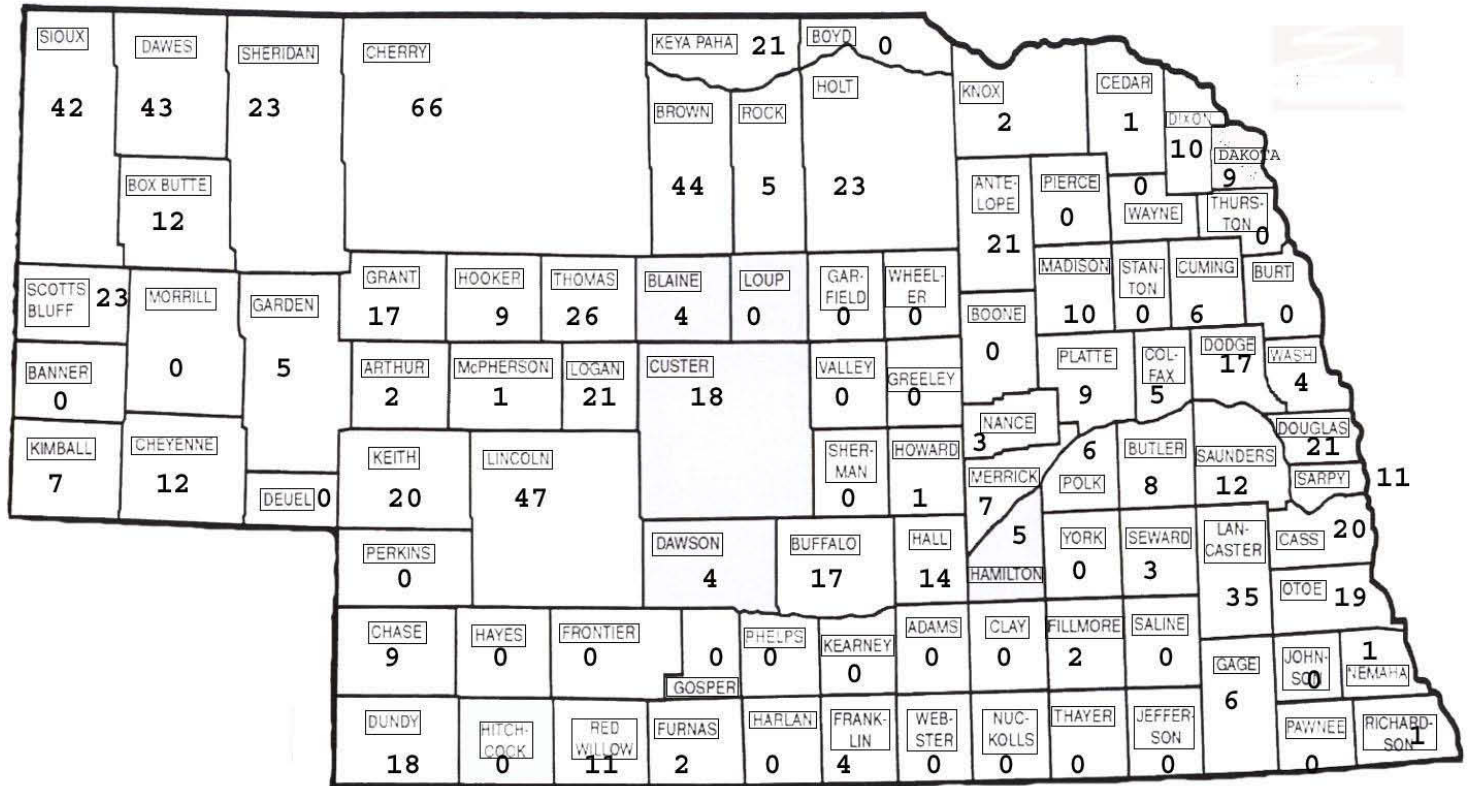

MAP 6 NEBRASKA COUNTY RECORDS 2004

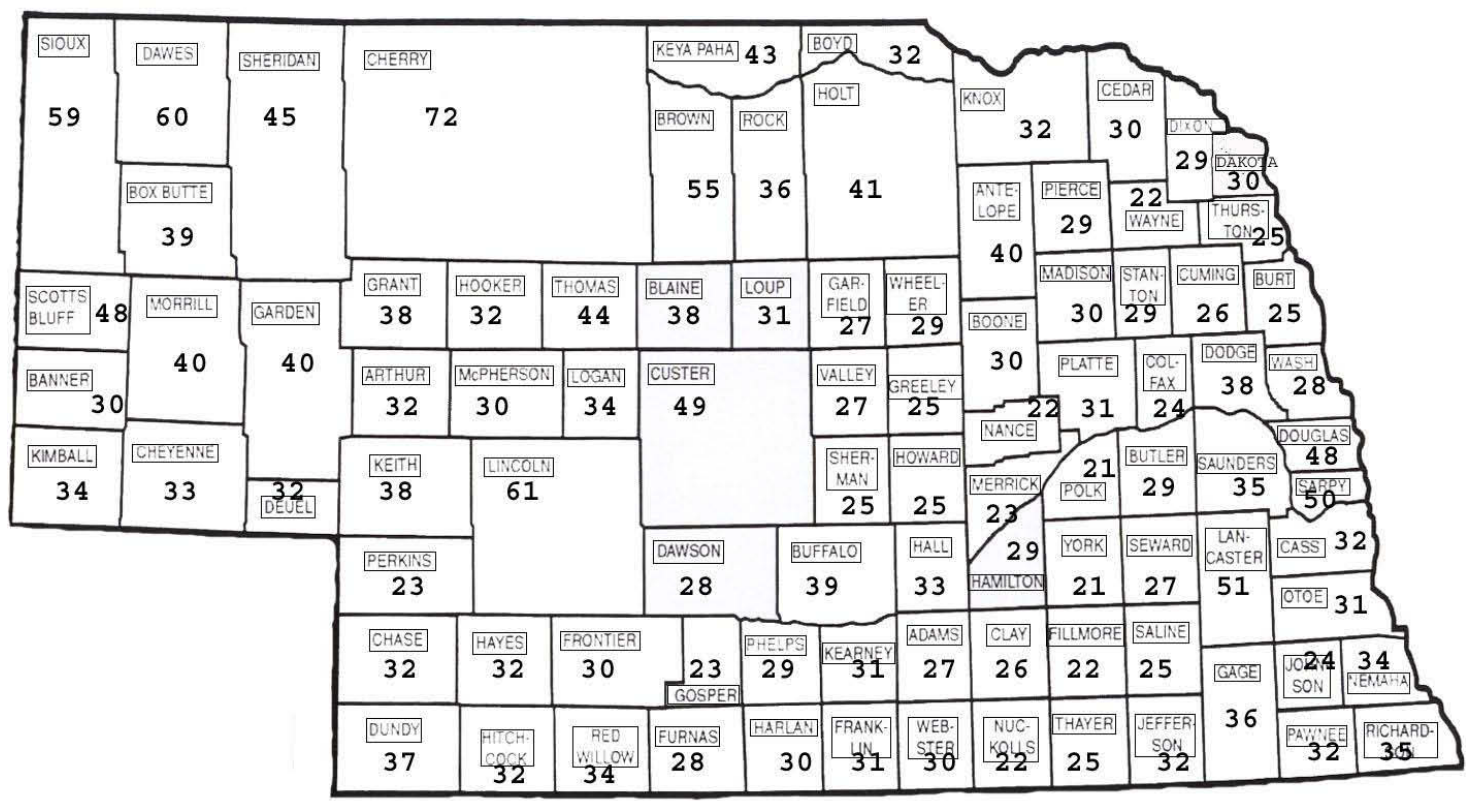

MAP 7 NEBRASKA COUNTY RECORDS 2017

recent collections for these 42 records. All the records used in this report are in Odonata Central and often with additional information on habitat, behavior and abundance. 


\section{SHORT HISTORY OF ODONATE COLLECTING IN NEBRASKA}

Until recently Nebraska has been ignored by odonatologists. Many states had an "Odonates of" publication before 1950, but Nebraska's best list is still an unpublished master's thesis (Keech, 1934) listing all the specimens in the University of Nebraska collection at that time.

Another indication of the paucity of attention paid to Nebraska are the Dot Maps (Donnelly, 2004a, b, c). The 1998 DSA meeting in Valentine added 9 species to the state list and increased county records by a third, but the Dot Maps still contained only 831 county records, about 8 per county, in 2004. A third of the counties had no records and two thirds had fewer than 10.

We have checked the following sources for specimen information: the University of Nebraska collection (UNSM) - about 3700 Nebraska specimens, International Odonata Research Institute(IORI) - 5100 Nebraska specimens (4/5th from the present study), Smithsonian (USNM) about 400 (mostly from 1998 meeting in Valentine), University of Texas as contained in Odonata Central (OC), Steve Hummel's collection, small teaching collections at University Nebraska Kearney and Chadron State College, field notes from Jerrell Daigle, Nick Donnelly, George Harp, Steve Krotzer, Dennis Paulson, Ken Tennessen and Hal White (a combined total of approximately 800 records).

The collections of John Abbott and Greg Lasley are contained in the University of Texas listing in OC, those of George Bick, Duncan Cuyler, Sid Dunkle, Bill Mauffray, B.E. Montgomery (part), Fred Sibley and Ken Tennessen are at IORI. Oliver Flint's specimens are in USNM. We have also checked all Nebraska records in Odonata Central and literature records. The literature on Nebraska, as one would expect, is limited.

Roy Beckemeyer pointed me to a reference (Uhler, 1857) listing a Sympetrum from Fort Union, Nebraska, but pointed out this was in the Nebraska Territory not Nebraska (National Historical Site near Williston, ND).

\section{7-1934}

The earliest specimen in the UNSM collection is from 1887 (Arigomphus cornutus - Horned Clubtail - Cuming County). There are only 55 specimens of 18 species from 6 counties prior to 1909. Half are from Cuming County (northeast part of state) and almost half are Amphiagrion (Red Damsel).

In 1910 Muttkowski published Catalogue of the Odonates of North America and listed Gomphus (Gomphurus) externus (Plains Clubtail), Stylurus olivaceus (Olive Clubtail) and Sympetrum assimilatum = rubicundulum (Ruby Meadowhawk) from Nebraska and credited Lawrence Bruner of Lincoln, Nebraska, for a list of Nebraska odonates. L. Bruner was the head of the Dept. of Entomology and Ornithology at the University of Nebraska and world expert on grasshoppers, but also a founder and first president of the Nebraska Ornithologists' Union. One would presume his odonate list was larger than 3. Muttkowski included Nebraska in the range 
of 15 additional species although not specifically mentioning the state. So Bruner's list may well have contained all the 18 species present in the UNSM collection at that time. Needham \& Heywood, 1929, copy Muttkowski in listing only 3 species for Nebraska.

From 1909-1915, L.M. Gates, E.G. Anderson, L. Bruner, C.W. Dawson, E.M. Partridge, E.J. Taylor and W. Thompson collected 800 specimens of 60 species from 20 counties. Possibly L. Bruner organized this collecting although Keech (1934) in the introduction to his thesis says, "Much credit is due L.M. Gates who started the work on the order Odonata in Nebraska. He has made most of the collections here studied and also has identified a number of the specimens." This collecting stopped after 1915 (WWI?) and only 3 specimens are present from the 1916-1920 period and 56 more between 1920 and 1934, when Keech wrote his thesis based on about 900 specimens.

Spotty collecting and concentration on certain species and certain counties was general into the present century. Keech had material from only 31 counties with a concentration on eastern and western counties. As an example of uneven collecting, all the 1909 material was from Antelope County with 30 of the 35 specimens being Ischnura verticalis (Eastern Forktail).

In 1934 Keech submitted his master's thesis based on identifying and listing the Odonate material in the UNSM collection. The thesis contains keys modified from Needham \& Heywood (1929) plus a summary of specimens. If there are only a few specimens, the date, sex and locality are given. If more specimens are known, there is a summary of numbers of males and females and a summary of the dates and counties where they were collected. He lists 62 species in the collection at that time but through misidentification and oversight these represent only 57 current species ( 26 zygoptera and 31 anisoptera). All subsequent publications on Nebraska odonates have covered only a few species or been simple lists with minimal or no supporting data.

\section{$1935-1960$}

J.H. Bratt working for Montgomery in 1937 collected 61 specimens (now in USNM collection) in the Lincoln area, including 22 Ischnura barberi (Desert Forktail)- a new species for the state. This species has still not been found in Nebraska outside the Lincoln area (Lancaster County).

From the time of Keech's thesis to 1950 only 14 specimens had been added to the UNSM collection. In 1951 and 1952 Donnabeth (D.B.) Weider with R.B. Cummings collected 450 specimens for the B. E. Montgomery collection (now in IORI collection). These represented 36 species from 7 counties with over 90 percent from the North Platte area, Lincoln County.

In 1952 and 1953 Donnabeth Weider also added 620 specimens to the UNSM collection covering 34 species and 18 counties, but the majority were, again, from the North Platte area.

In all three years this collecting was fairly evenly spread through the flight season except for an 8 day surge in August 1951 when 350 specimens were collected. 
Needham and Westfall (1955), aside from dropping Stylurus olivaceus and failing to note Aeshna interrupta (Variable Darner), make no changes to the Keech (1934) anisoptera records. This is, however, the first published listing of 29 anisoptera species.

Kormondy (1957) made a small collection in 1955 and added Lestes congener to the state list as well as publishing 5 of Keech's zygoptera species. Kormondy (1960) added Aeshna canadensis (Canada Darner) to the Nebraska list.

\section{$1961-1990$}

Over 1400 specimens were added to the UNSM collection during this period consisting mainly of specimens from the Hastings College collection and the collection of Neva Pruess. Neva Pruess, a recent PhD of Donald Borror, moved, with her husband, to North Platte in 1963. During 1963 and 64, she collected over 700 specimens in the North Platte area. After moving to the University of Nebraska Lincoln she collected additional specimens in the Lincoln area and donated all to the UNSM collection. But some of her specimens were not identified until 2006, so she missed adding Argia nahuana (Aztec Dancer) and A. plana (Springwater Dancer) to the state list. Pruess (1967) did add 12 species to the state list: Lestes australis (Southern Spreadwing), Argia alberta (Paiute Dancer), Argia emma (Emma's Dancer), Argia moesta (Powdered Dancer), Argia sedula (Blue-ringed Dancer), Enallagma basidens (Double-striped Bluet), Enallagma exsulans (Stream Bluet), Enallagma geminatum (Skimming Bluet), Nehalennia irene (Sedge Sprite), Aeshna palmata (Paddle-tailed Darner), Progomphus obscurus (Common Sanddragon) and Leucorrhinia intacta (Dot-tailed Whiteface). Most, 21 species, of the zygoptera listed by Keech (1934) are published in Pruess (1967) for the first time as well as the Aeshna interrupta overlooked by Needham and Westfall (1955).

Montgomery (1967) added Ischnura barberi (Desert Forktail) and Sympetrum madidum (Redveined Meadowhawk) to the Nebraska list in a paper based on his collection and Pruess' list.

The combined list of Pruess and Montgomery, the second complete list of Nebraska odonates, totaled 74 species - 38 zygoptera and 36 anisoptera.

George Bick and wife, Bick \& Hornuff (1972), crossed the state going west to Wyoming June 2324,1971 ) and coming east from Wyoming July $17-19,1969$. I find it amazing that in the relatively casual collecting of 25 species during the 2 trips they had the first and still only records for Coenagrion resolutum (Taiga Bluet) and Sympetrum ambiguum (Blue-faced Meadowhawk).

After Pruess' collecting in 1964 the UNSM collection added an average of 30 specimens a year with little focused collecting. Many of these also remained unidentified until 2006. Approximately 100 vials of odonate nymphs, collected in 19 counties of northeast and southeast Nebraska during 1984, 1985 and 1986 are housed in the University of Nebraska State Museum. These were presumably collected by Troelstrup, et al. (no collector on labels) who 
reported (Troelstrup, et al. 1985) on the first record of Neurocordulia molesta (Smoky Shadowdragon) from Nebraska. An examination and re-identification of 30 vials by Ken Tennessen turned up the first record of Macromia (River Cruiser) for Nebraska, the earliest specimen records for Boyeria vinosa (Fawn Darner) and Gomphus militaris (Sulphur-tipped Clubtail) plus eight new county records for Gomphus externus (Plains Clubtail).

\section{1 to present}

The 1998 DSA meeting in Valentine, Cherry County, was a major advance for knowledge of Nebraska odonates. Specimen collecting in 1997 and 1998 related to the DSA meeting and planning for the meeting in Valentine (Cherry County) added close to 2000 specimens to private and museum collections. As an example, 300 of the 370 Nebraska specimens at USNM and 430 of the 1100 at IORI (as of the year 2000) are from this meeting.

The Beckemeyer $(1998 b)$ and Beckemeyer and Hummel $(1997,1998)$ reports on the 1998 DSA meeting list over 400 county records from 26 counties representing 82 species - $91 \%$ of the state list at that time and almost $50 \%$ of the county records. Ten species were added to the state list: Argia plana (Springwater Dancer), Enallagma aspersum (Azure Bluet), Enallagma signatum (Orange Bluet), Ischnura hastata (Citrine Forktail), Arigomphus submedianus (Jade Clubtail), Gomphurus graslinellus (Pronghorn Clubtail), Gomphurus militaris (Sulphur- tipped Clubtail), Stylurus notatus (Elusive Clubtail), Celithemis elisa (Calico Pennant). The Epitheca costalis specimens listed as new were actually E. cynosura and petechialis (new). The Leucorrhinia hudsonica also listed as new for the state was L. intacta - corrections by Nick Donnelly.

The third complete list comes from an unpublished manuscript, Beckemeyer (1999a \& b), with 90 current species, 42 zygoptera and 48 anisoptera.

Donnelly (2000) added Brachymesia herbida and Libellula auripennis to the state list by reidentifying specimens in UNSM formerly labeled $B$. gravida and L. flavida.

Paul Johnsgard's (2001) Nature of Nebraska contains a list (circa 1997) of 93 species, 85 currently accepted as valid state records. Unfortunately, since this is an excellent book by a popular author and will have a large number of readers, several errors in the literature are perpetuated.

In 2003 and 2004 collectors added some 350 specimens to the UNSM collection, but mostly from wetland studies in Cherry and Lancaster Counties.

In 2005 Fred and Peggy Sibley started systematically visiting all the Nebraska counties. What started as a 2-3 year project continued, with the exception of 2007, each summer to 2014. Adding county records proved more difficult than planned. We were not in New York anymore and raising a county species list to 10 species took visits to multiple habitats and sometimes a 
repeat visit the next year. Even abundant and widespread species like Enallagma civile (Familiar Bluet) and Ischnura verticalis (Eastern Forktail) were not guarantees.

In the later years an effort was made to check museums and track down specimens for existing dot map records. This resulted in dropping some species and some county records from the state list.

Now, over 2000 new county records later, each of the 93 counties has at least 21 species, the county records for almost all species have more than doubled, 12 species have been added to the state list and 4000 specimens have been added to the IORI collection. All the county records for Nebraska have been entered in Odonata Central. The 12 species added to the state list during the time of this survey include a number of earlier sight records or specimens never published. These are indicated by \# after the name: Argia nahuana (Aztec Darner)\#, Enallagma traviatum (Slender Bluet)\#, Enallagma vesperum (Vesper Bluet)\#, Nasiaeschna pentacantha (Cyrano Darner), Dromogomphus spoliatus (Flag-tailed Spinyleg), Erpetogomphus designatus (Eastern Ringtail)\#, Stylurus plagiatus (Russet-tipped Clubtail), Epitheca petechialis (Dotwinged Baskettail)\#, Epitheca spinigera (Spiny Baskettail), Dythemis fugax (Checkered Setwing), Sympetrum danae (Black Meadowhawk), Tramea calverti (Striped Saddlebag).

\section{BIOGEOGRAPHY}

Beckemeyer (2002), in analyzing the distribution of Great Plains odonates, separated species into six geographic categories. Roy's geographic categories (transcontinental now split into north and south) have proved very useful in commenting on distribution, and the 109 Nebraska species are split as follows: Eastern (37), Western (17), Transnorth (28), Transsouth (12), Central (11), Southwestern (2) and Tropical (2). Appendix E lists all 109 Nebraska species with their geographical allocation.

Roy's study was limited by the data available at the time and covered a much larger area, so we have not attempted to compare our Nebraska data to his study.

Some of the increase in data since 2002 is indicated by the increase in Nebraska county records for the following species: Lestes australis (Southern Spreadwing) from 2 county records to 38, Argia alberta (Paiute Dancer) 5 CR to 39, Argia apicalis (Blue-fronted Dancer) 17 CR to 80, Enallagma antennatum (Rainbow Bluet) 7 CR to 54, Enallagma exsulans (Stream Bluet) 3 CR to 25, Enallagma signatum (Orange Bluet) 2 CR to 28, Anax junius (Common Green Darner) 16 CR to 88 , Phanogomphus militaris (Sulphur-tipped Clubtail) 1 CR to 20, Progomphus obscurus (Common Sanddragon) 4 CR to 24, Epitheca petechialis (Dot-winged Baskettail) 1 CR to 16, Celithemis elisa (Calico Pennant) 1 CR to 28, Celithemis eponina (Halloween Pennant) 6 CR to 65, Tramea lacerata (Black Saddlebags) 12 CR to 91 . Total county records have increased from 831 to 3103.

Only two tropical species [Brachymesia herbida (Tawny Pennant) and Tramea calverti (Striped Saddlebags)] and two southwestern species [Ischnura barberi (Desert Forktail) and Dythemis 
fugax (Checkered Setwing)] have been recorded in Nebraska and all but Ischnura barberi are accidental.

Since many species reach their eastern and western limits in Nebraska, we start with these groups. Nebraska's affinities are definitely with the east. The 37 eastern species represent over a third of the Nebraska species, county records, and 22 of the 55 commonest species. By contrast, western species account for only 10-15 percent of the Nebraska species and county records, while only 3 species are considered common or fairly common. Transnorth species are basically eastern; transsouth species are eastern and/or southern.

\section{EASTERN SPECIES}

For comparison we have split the area from western lowa to eastern Wyoming into $7 \mathrm{~N}-\mathrm{S}$ bands with 1 band, 2 counties wide, in western lowa, 1 band of 5 counties in eastern Wyoming and 5 bands, 2-3 counties wide, across Nebraska. Going east to west, the average number of records per county for the 37 eastern species in lowa is 16.0. It gradually drops as one goes west across Nebraska , 13.6, 12.4, 12.2, 10.8 and 8.5., before plummeting to 3.2 in the eastern Wyoming counties (see Table A).

Table A - AVERAGE NUMBER OF SPECIES IN EACH N-S BAND

\begin{tabular}{|c|c|c|c|c|c|c|c|c|}
\hline WY & NE5 & NE4 & NE3 & NE2 & NE1 & IA & $\mathbf{N E}$ & \\
\hline 3.2 & 8.5 & 10.8 & 12.2 & 12.4 & 13.6 & 16.0 & 37 & Eastern \\
\hline 12.0 & 10.1 & 5.0 & 2.9 & 1.5 & 1.6 & 2.7 & 17 & Western \\
\hline 12.2 & 13.3 & 10.8 & 7.5 & 4.5 & 6.5 & 12.1 & 28 & Transnorth \\
\hline 3.8 & 7.4 & 8.6 & 8.4 & 7.6 & 8.7 & 8.5 & 12 & Transsouth \\
\hline 1.6 & 2.6 & 2.4 & 1.4 & 1.2 & 2.7 & 4.1 & 11 & Central \\
\hline
\end{tabular}

WY $=5$ eastern counties (Laramie, Platte, Goshen, Converse, Niobrara) abutting Nebraska. NE5 is the Panhandle, NE4 is Cherry County and counties south of there. NE3 is Keya Paha and Boyd Counties south, NE2 is Knox and Cedar Counties south, NE1 is Dixon and Dakota Counties south, IA is Lyon and Osceola Counties south. NE is number of species found in Nebraska of that biogeographic group.

The total number of eastern species in all the counties in the lowa band is 33 and continues at 30 or slightly above in the 3 bands to central Nebraska. Then species count drops to 26 and 16 in the two western Nebraska bands and to 9 in the eastern Wyoming counties abutting Nebraska (see Table B). Only 2 eastern species go west of these Wyoming counties: Ischnura verticalis (Eastern Forktail) with 3 more western county records and Sympetrum rubicundulum (Ruby Meadowhawk) with 3 more records, but these extending to the Rockies. A number of species found in the Panhandle of Nebraska disappear or become rare only a short way into Wyoming. In the following list of 8 eastern, 5 transouthern, 1 western and 1 central species, the first number is the number of the 11 Panhandle counties where the species is found and the second is the number of Wyoming counties where the species is found. Calopteryx maculata (Ebony Jewelwing - E) 7/1; Lestes rectangularis (Slender Spreadwing - E) 8/0; Argia nahuana (Aztec Dancer - W) 3/0; Enallagma basidens (Double-striped Bluet - E) 7/1; Epitheca cynosura 
(Common Baskettail - E) 8/1; Epitheca petechialis (Dot-winged Baskettail - C) 7/1; Celithemis elisa (Calico Pennant - E) 4/0; Celithemis eponina (Halloween Pennant - E) 6/0; Erythemis simplicicollis (Eastern Pondhawk - E) 10/0; Libellula luctuosa (Widow Skimmer - TS) 11/4; Pachydiplax longipennis (Blue Dasher - TS) 9/0; Perithemis tenera (Eastern Amberwing - E) 3/0; Sympetrum vicinum (Autumn Meadowhawk - TS) 2/0, Tramea lacerata (Black Saddlebags - TS) 9/0, Tramea onusta (Red Saddlebags - TS) 3/0

Table B - NUMBER OF SPECIES IN EACH N-S BAND

WY NE5
\begin{tabular}{|r|r|r|r|r|r|r|r|l|}
\hline 9 & $\mathbf{1 6}$ & $\mathbf{2 6}$ & $\mathbf{3 0}$ & $\mathbf{3 1}$ & $\mathbf{3 3}$ & $\mathbf{3 3 4}$ & $\mathbf{3 7}$ & Eastern \\
\hline 16 & $\mathbf{1 7}$ & $\mathbf{1 4}$ & $\mathbf{9}$ & $\mathbf{6}$ & $\mathbf{5}$ & $\mathbf{5}$ & $\mathbf{1 7}$ & Western \\
\hline b23 & $\mathbf{2 3}$ & $\mathbf{2 5}$ & $\mathbf{2 4}$ & $\mathbf{1 7}$ & $\mathbf{1 9}$ & $\mathbf{2 3}$ & $\mathbf{2 8}$ & Transnorth \\
\hline 6 & $\mathbf{1 0}$ & $\mathbf{1 2}$ & $\mathbf{1 2}$ & $\mathbf{1 2}$ & $\mathbf{1 2}$ & $\mathbf{1 1}$ & $\mathbf{1 2}$ & Transsouth \\
\hline 2 & $\mathbf{8}$ & $\mathbf{9}$ & $\mathbf{8}$ & $\mathbf{7}$ & $\mathbf{8}$ & $\mathbf{c 1 1}$ & $\mathbf{1 1}$ & Central \\
\hline
\end{tabular}

a Includes 4 eastern species not found in Nebraska

b Includes 4 transnorth species not found in Nebraska

c Includes 1 central species not found in Nebraska

This decline as one crosses into Wyoming is likely real and not a lack of collecting.

The divide between eastern Nebraska and western lowa is not as sharp but there are five eastern species recorded in western lowa that have not been found in Nebraska (the number shown is the number of county records in the western two bands of lowa counties) : Hetaerina titia (Smoky Rubyspot - 3), Lestes inaequalis (Elegant Spreadwing - 1), Aeshna verticalis (Greenstriped Darner - 1), Gomphurus fraternus (Midland Clubtail - 2), Epitheca costalis (Slender Baskettail - 1) and one Midwestern species Coenagrion angulatum (Prairie Bluet - 4).

If we compare the six Game and Parks regions (a north/south comparison - Table C) the percentage of county records composed of eastern species is considerably higher in the southern counties and declines east to west less rapidly than in the northern counties. As example the percentage of records represented by eastern species in the Northeast is 38.4 vs 46.4 in the Southeast, Sandhills 31.4 vs 45.7 in Southcentral region.

Table C - PERCENTAE OF GAME AND PARKS REGIONS' COUNTY RECORDS BY BIOGEOGRAPHIC GROUP

Trans Trans

\begin{tabular}{|l|r|r|r|r|r|}
\multicolumn{1}{l|}{ Region } & \multicolumn{1}{c}{ West } & \multicolumn{1}{c|}{ north } & \multicolumn{1}{c|}{ south } & Central \\
\hline Northeast & $\mathbf{3 8 . 4}$ & $\mathbf{6 . 9}$ & $\mathbf{2 1 . 2}$ & $\mathbf{2 7 . 4}$ & $\mathbf{6 . 2}$ \\
\hline Sandhills & $\mathbf{3 1 . 4}$ & $\mathbf{1 1 . 0}$ & $\mathbf{3 0 . 0}$ & $\mathbf{2 2 . 8}$ & $\mathbf{4 . 9}$ \\
\hline Panhandle & $\mathbf{2 0 . 2}$ & $\mathbf{2 4 . 1}$ & $\mathbf{3 1 . 7}$ & $\mathbf{1 7 . 6}$ & $\mathbf{6 . 3}$ \\
\hline Southeast & $\mathbf{4 6 . 4}$ & $\mathbf{3 . 7}$ & $\mathbf{1 7 . 0}$ & $\mathbf{2 5 . 3}$ & $\mathbf{7 . 7}$ \\
\hline Southcentral & $\mathbf{4 5 . 7}$ & $\mathbf{6 . 5}$ & $\mathbf{1 5 . 2}$ & $\mathbf{2 8 . 8}$ & $\mathbf{3 . 8}$ \\
\hline Southwest & $\mathbf{3 0 . 4}$ & $\mathbf{1 3 . 2}$ & $\mathbf{2 5 . 4}$ & $\mathbf{2 4 . 7}$ & $\mathbf{6 . 4}$ \\
\hline
\end{tabular}




\section{WESTERN SPECIES}

Western species drop off quickly east of the Panhandle. Using the 7 bands used for eastern species, the average number of the 17 western species per county is 10.6 in eastern Wyoming, 10.1 in the Panhandle, 5.0, 2.9, 1.5, 1.6 across the rest of Nebraska and 2.7 in western lowa, but species ranging east of the Panhandle may go across lowa or even as accidentals to the east coast. The total number of western species found in each band does not drop as sharply. Argia nahuana, more southern in range, does not occur in Wyoming, so the count of western species in eastern Wyoming is 16 followed by 17 in the Panhandle, 14, 9, 6, 5 in the Nebraska bands going east and 5 species in lowa.

As mentioned earlier, only two eastern species get very far into Wyoming, but two western species go way past lowa. Enallagma anna (River Bluet) reaches eastern Ontario and Sympetrum corruptum (Variegated Meadowhawk), at least as an accidental, is recorded in almost every state.

Beckemeyer (2002) says: "Bick's 1957 assertion that the 32 to 36 inch precipitation isolines correlated with the area of overlap of eastern and western species groups in Oklahoma appears to hold true for Kansas as well." This is certainly not true in Nebraska, where the Panhandle or areas just east would seem to be the overlap zone, an area where the rainfall is less than 25 inches.

\section{EAST/WEST SPECIES PAIRS}

A number of species pairs meet in Nebraska with widely differing results. All the Red Damsels, Amphiagrion saucium (Eastern Red Damsel) and A. abbreviatum (Western Red Damsel), in Nebraska are intergrades and not reliably separated to one species or the other. Argia plana (Springwater Dancer), eastern, and A. vivida (Vivid Dancer), western, meet in central Nebraska but do not seem to overlap. This is worth further study as the two are extremely difficult to distinguish and present at a limited number of streams. Ischnura verticalis (Eastern Forktail) meets its western equivalent, I. perparva (Western Forktail) in Nebraska, and the two have a wide band of overlap extending from central Nebraska to central Wyoming with no evidence of hybridizing. Erythemis simplicicollis (Eastern Pondhawk) and the western E. collocata (Western Pondhawk) do not come in contact in Nebraska. E. simplicicollis barely makes it to the Wyoming and Colorado borders. No Colorado populations contact the Nebraska border and Erythemis has only been found (E. collocata) in two northwestern Wyoming counties. Plathemis lydia (Common Whitetail) and $P$. subornata (Desert Whitetail), western, occupy some of the same streams in western Nebraska. Despite some minor differences in stream preferences, they overlap more than they separate in these streams and do not hybridize.

Although not an E-W pair; Epitheca cynosura (Common Baskettail), eastern, and E. petechialis (Dot-winged Baskettail), central, meet in Southwestern Nebraska and seem to hybridize - as intermediate specimens are known from 5 counties. 


\section{TRANSCONTINENTAL SPECIES}

The 40 transcontinental, transnorth (28) and transsouth (12), species are all more common and more generally distributed in the east than in the west although all, by definition, reach the west coast. They are all found in Pennsylvania and most in New York so all could be classified as primarily eastern. The transnorth species have a mostly continuous distribution across the northern US with Nebraska often at the southern limit of the range. In addition, some ranges bend north in the Great Plains, what I have called the Midwestern gap, so species can be found in western Nebraska and western lowa without occurring in eastern and central Nebraska. A milder version of this Midwestern gap results in an absence, or rarity, of some species in the SE corner of Nebraska. Using the same bands as in the discussion of Eastern species, we find the average species counts for transnorth species is 12.1 in western lowa, $6.5,4.5,7.5,10.8$, in the first 4 bands in Nebraska, while counts from the Panhandle (13.3) and Wyoming (12.2) are essentially double those at the Missouri River (6.5). This Midwestern gap is expressed many different ways. Species like Enallagma boreale (Boreal Bluet) and Libellula quadrimaculata (Four-spotted Skimmer) are regular in lowa and western Nebraska and absent from the intervening areas of Nebraska. Populations of Enallagma carunculatum (Tule Bluet) in lowa and Nebraska connect, but the species is much less common in eastern Nebraska than in the western parts of Nebraska and lowa. Sympetrum rubicundulum (Ruby Meadowhawk) becomes uncommon to rare in the SE corner of Nebraska but expected across the river in lowa and Missouri. All the transnorth species are less common in southern Nebraska than northern. As a result of this and the "gap" distribution, only the following six transnorth species are found in over half the Nebraska counties: Lestes unguiculatus (Lyre-tipped Spreadwing), Amphiagrion intermediate (Red Damsel), Enallagma carunculatum (Tule Bluet), Sympetrum internum (Cherry-faced Meadowhawk), S. obtrusum (White-faced Meadowhawk), and S. semicinctum (Band-winged Meadowhawk).

The transsouth species (12) are essentially southern in distribution and do not connect through the Great Plains north of Nebraska, although the ranges, both east and west of Nebraska, may extend further north than Nebraska. In any case, these twelve species represent eight of the ten commonest species in the state and account for slightly more county records than the more numerous transnorth species.

Unlike with the transnorth species, the average county count for transsouth species stays very similar (7 to 9 species) from western lowa to western Nebraska, but drops to 3.8 in eastern Wyoming. All 12 species are found in each band to the Panhandle (10 species) and eastern Wyoming (6 species).

\section{NORTH/SOUTH SPECIES PAIRS}

There are only a few north/south species pairs. The jewelwings, Calopteryx maculata (eastern) and $C$. aequabilis (transnorth), tend to replace each other in the northern band of counties with very little overlap. Lestes disjunctus (Northern Spreadwing) and the much more common $L$. australis (Southern Spreadwing) meet in the northern tier of counties although they have not 
been found together at any site. Arigomphus cornutus (Horned Clubtail), northern, and $A$. submedianus (Jade Clubtail), southern, overlap slightly only in the northeastern counties, as cornutus goes west in Nebraska and submedianus does not.

\section{CENTRAL SPECIES}

The Central (Great Plains) group of 11 species is top heavy with gomphids (7), and contains no Libelullidae (Pond Dragonflies). The other groups are two damselflies and two cordulids. The records for these fairly common species are relatively evenly spread across the plains to eastern Wyoming where only Ischnura damula (12 CR) and Gomphurus externus (2CR) are found. None of the Central species are common in Nebraska: The most frequently found, Gomphurus externus (Plains Clubtail), is in just over a third (37) of the counties. Phanogomphus militaris (Sulphur-tipped Clubtail) is found in just under a fifth (20) and most of the rest in fewer than 10 counties.

\section{Table D - NUMBER OF COUNTY RECORDS PER GAME AND PARKS REGION BY BIOGEOGRAPHIC GROUP}

Trans Trans Other

\begin{tabular}{|l|r|r|r|r|r|r|r|}
\multicolumn{1}{l}{ Region } & \multicolumn{1}{c}{ East } & \multicolumn{1}{c}{ West } & north south Central & \multicolumn{1}{c|}{ Total } \\
\hline Northeast & 212 & 38 & 117 & 151 & 34 & 0 & 552 \\
\hline Southeast & 226 & 18 & 83 & 123 & 37 & 2 & 489 \\
\hline Sandhills & 200 & 70 & 191 & 145 & 31 & 0 & 637 \\
\hline Southcentral & 238 & 34 & 79 & 150 & 20 & 1 & 522 \\
\hline Southwest & 134 & 58 & 112 & 109 & 28 & 2 & 443 \\
\hline Panhandle & 93 & 111 & 146 & 81 & 29 & 0 & 460 \\
\hline Total & 1103 & 329 & 728 & 759 & 179 & 5 & 3098 \\
\hline
\end{tabular}

Table E -NUMBER OF SPECIES PER GAME AND PARKS REGION BY BIOGEOGRAPHIC GROUP

TransTrans Central

Region
\begin{tabular}{|l|r|r|r|r|r|r|}
\hline Northeast & $\mathbf{3 0}$ & $\mathbf{6}$ & $\mathbf{1 8}$ & $\mathbf{1 2}$ & $\mathbf{6}$ & $\mathbf{7 2}$ \\
\hline Southeast & $\mathbf{3 3}$ & $\mathbf{5}$ & $\mathbf{1 9}$ & $\mathbf{1 2}$ & $\mathbf{7}$ & $\mathbf{7 6}$ \\
\hline Sandhills & $\mathbf{2 7}$ & $\mathbf{1 2}$ & $\mathbf{2 6}$ & $\mathbf{1 2}$ & $\mathbf{1 0}$ & $\mathbf{8 7}$ \\
\hline Southcentral & $\mathbf{2 8}$ & $\mathbf{7}$ & $\mathbf{1 4}$ & $\mathbf{1 2}$ & $\mathbf{5}$ & $\mathbf{6 6}$ \\
\hline Southwest & $\mathbf{2 1}$ & $\mathbf{1 3}$ & $\mathbf{2 1}$ & $\mathbf{1 2}$ & $\mathbf{8}$ & $\mathbf{7 5}$ \\
\hline Panhandle & $\mathbf{1 6}$ & $\mathbf{1 7}$ & $\mathbf{2 3}$ & $\mathbf{1 0}$ & $\mathbf{8}$ & $\mathbf{7 4}$ \\
\hline Species & $\mathbf{3 7}$ & $\mathbf{1 7}$ & $\mathbf{2 8}$ & $\mathbf{1 2}$ & $\mathbf{1 1}$ & $\mathbf{1 0 5}$ \\
\hline
\end{tabular}

\section{BLACK HILLS, SOUTH DAKOTA}

The Black Hills represent an isolated oasis of forest, abundant water and odonate habitat just 30 miles north of the badlands of Sioux County, Nebraska. A number of species have isolated populations here. In the town of Hot Springs, South Dakota, one finds the southwestern species 
Argia immunda (Kiowa Dancer), Brechmorhoga mendax (Pale-faced Clubskimmer), and Libellula saturata (Flame Skimmer). A. immunda and L. saturata are dominate over their congeners and abundant while Brechmorhoga is the sole representative of this genus north of Arizona. It is possible that during an extended period of wet years, one or more of these species would show up in northern Sioux or Dawes County. In addition, there are, connected to the Black Hills, less restricted but still isolated populations of Calopteryx aequabilis (River Jewelwing), Aeshna canadensis (Canada Darner), Erpetogomphus designatus (Eastern Ringtail), Phanogomphus graslinellus (Pronghorn Clubtail), and Epitheca petechialis (Dot-winged Baskettail). The first two extend south into northern Nebraska and the last three are found in southern Nebraska at the northern limit of the main population.

In summary, the odonate fauna of Nebraska is primarily eastern ( 37 species, $1103 \mathrm{CR}$ ) and transsouth (12 species, 759 CR) with a considerable number of transnorth ( 28 species, 728 CR). The western species records (17 species, 329 CR) are primarily from the Panhandle. See Tables $D$ and $E$ above.

\section{SPECIES ACCOUNTS - Identifying Dragonflies and Damselflies}

Scattered through the species accounts are identification tips for the beginner or those unfamiliar with Nebraska dragonflies and damselflies (i.e. Odonates). Females and immatures are often very difficult to identify, so these tips primarily apply to adult males and are intended only as an introduction to the study of this group. Once you learn the more conspicuous species you are ready for one of the field guides, or better, a friend who knows more than you about Nebraska odonates. Note that some species and particularly many females are difficult to separate and may require netting and examination with a hand lens or in a few cases a microscope. There is nothing wrong with enjoying just the ones you can identify easily. There are pond species, stream species, river species, Spring species, Fall species, ones that fly only late in the day, ones that fly only after sunset, northern species, western species, etc., and all of these traits can be used to help in identification. Size and behavior are also useful, but at some point, check a field guide to see if your identification fits.

In Nebraska, the best time to find most dragonflies is between 11AM and 2PM, from the last week of June through the second week of July and on days when the sun is shining and the temperature is above $\mathbf{7 0}$ degrees. Some migrant species, however, will arrive in mid-May and a few species will still be found in late October: Aeshna (darners) and Sympetrum (meadowhawks), but by mid-July diversity starts to decline and by mid-August it will be limited.

\section{KEY TO SPECIES ACCOUNTS}

Scientific and English names are those used by Odonata Central.

CR - Total number of county records out of possible 93. Dec. 2017 was the cutoff for records.

TL - Total length in millimeters $(25 \mathrm{~mm}=1$ inch $)$ 
Spec: The earliest known specimen. Unless otherwise indicated, the record is from the University of Nebraska State Museum (UNSM). Other records will be indicated by: IORI for International Odonata Research Institute at the University of Florida, Gainesville; USNM for United State National Museum (Smithsonian); names of various private or small college collections.

Pub: The year the species name was first published in connection with a correctly identified specimen. The master's theses of Keech, 1934, and Moody, 1967, were never published, but we have cited them, where applicable, for first publication date. The Zygoptera records of Keech were first published by Pruess, 1967, and Anisoptera records by Needham \& Westfall, 1955. Moody's records were published by Pruess, 1967, or Montgomery, 1967.

FP: The flight period is based on known specimens. We have a database of almost 10,000 specimens, 3103 unique county records, as listed in the historical account.

Maps: The counties colored black represent Dot Map (Donnelly 2004a, b, c) records and the green counties represent records added between 2004 and 2017.

\section{NEBRASKA ODONATES}

The following species accounts summarize what we think we know about Nebraska odonates.

The Nebraska odonate list has 109 species in two suborders, damselflies (Zygoptera) with 47 species and dragonflies (Anisoptera) with 62 species.

\section{ZYGOPTERA (DAMSELFLIES)}

There are three families and 47 species of damselflies in Nebraska:

Calopterygidae - Broad-winged Damsels: The two genera and three species in this family are large damselflies (40-55 mm long), with either large amounts of black in the wings or a conspicuous red spot at the base of the wing, and are found on streams and rivers.

Calopteryx - Jewelwings: Only two iridescent green/blue species of this genus are found in Nebraska and states to the west. They are easily separated and there is no likelihood of additional species $-C$. aequabilis with black wing tips and $C$. maculata with all black wings.

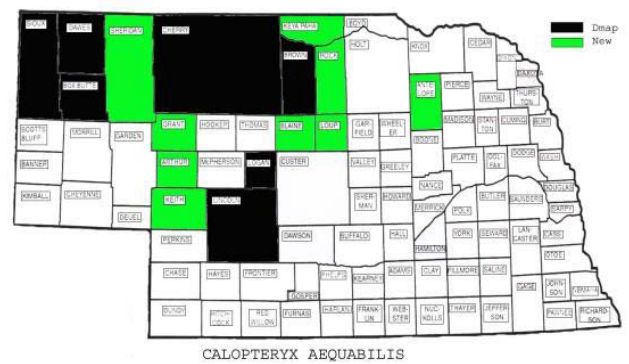

CALOPTERYX AEQUABILIS

\section{Calopteryx aequabilis (River Jewelwing)}

CR: 16, TL: 46-54mm, Spec: 1910, Pub: Keech, 1934

FP: mid-June to mid-August

this species is uncommon statewide, but common to 
abundant locally and inhabiting primarily northern counties in the western half of state. It seems to be split into (1) a population east of eastern Nebraska, South and North Dakota (a seemingly valid gap in distribution), (2) a population west of the Rocky Mountains, and (3) a population in western Nebraska and the Black Hills of South Dakota that extends north into Canada.

Although it is recorded in all northern lowa counties right up to the Nebraska border, a single individual in Antelope County is the farthest east it has been recorded in Nebraska. Clear, flowing, sand-bottomed streams are the normal habitat. Bloody Creek on the Loup/Rock county line, the upper reaches of the Middle Loup River (Cherry and Grant counties) and the upper reaches of the South Loup (Logan County) are all excellent areas for the species. These rivers are barely streams in their headwaters where this species is common. Calopteryx maculata is frequently found in the same streams with $C$. aequabilis, but one or the other species will be far more common. The forewing black tips in New York specimens are significantly shorter/smaller than those from Nebraska.

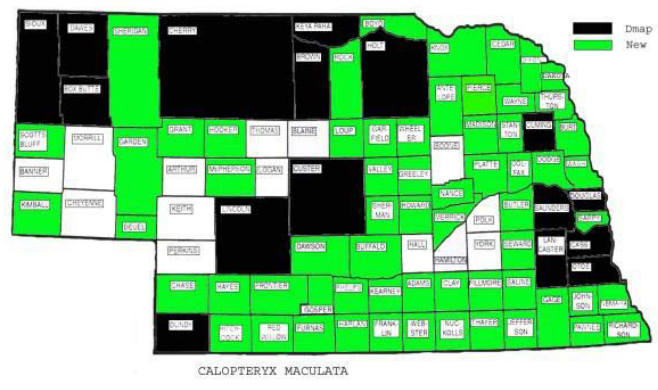

\section{Calopteryx maculata (Ebony Jewelwing)}

CR: 80, TL: 39-57mm, Spec: 1888, Pub: Keech, 1934

FP: late May to mid-Sept.

Very common. This is an eastern species near its western and northern limits in Nebraska (there are

two county records from Colorado and a number from the Black Hills). It is present in a large variety of small streams from sandy to mud and open to heavily-shaded, but absent from larger streams and rivers. This conspicuous flashy species is often abundant and sometimes the most common species in a stream. It is rare or absent in many Sandhills counties, some because of the absence of streams, and less common in western counties. Its absence or rarity in a few eastern counties is unexplained. In Cedar County it was super abundant and the only odonate in a ditch/stream north of Obert on July 27, 2005. It is one of the first species to fly in the early morning, when it can be found sitting on bank vegetation in full sun. It is also active later in the day and in poorer weather than most damselflies.

Hetaerina - Rubyspots: There are only two species in the western US, but Hetaerina titia (Smoky Rubyspot), although present in western lowa, has not been found in eastern Nebraska. Few damselflies are this large and no others have the red spot at the base of the wing.

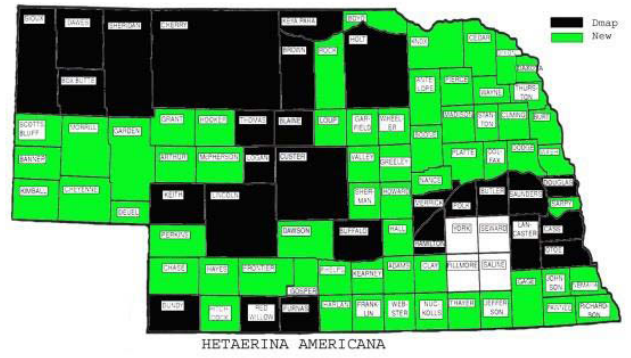

\section{Hetaerina americana (American Rubyspot)}

CR: 89, TL: 40-46mm, Spec: 1910, Pub: Keech, 1934

FP: early May to mid-October 
Very common. This transcontinental species is found with Calopteryx in some situations, but it prefers larger streams and rivers, where it usually flies close to the bank and perches on vegetation hanging over the water. It is occasionally found on ponds and lakes in Sandhills counties when no suitable streams are present, but as single individuals. When found on streams or small rivers it is almost always common. Like the jewelwings, this species shows up early in the day and stays late. The only area of Nebraska where it has not been found is a four county block (York, Seward, Saline, Fillmore) in the Big Blue River drainage. We have checked most streams in the area and even spend a whole day at the end of the study looking for just this species without success.

Lestidae - Spreadwings: The two genera and eight species of this family are almost exclusively found in marshes or temporary wetlands and tend to have inconspicuous markings. They normally perch, as name implies, with wings half spread. There is one large species (50-60 mm), while the others are moderate sized $(33-45 \mathrm{~mm})$ and slightly larger than individuals of the pond damsel family,

Archilestes - Stream Spreadwings: The one species is a late season species and is considerably larger than any Lestes. The conspicuous yellow stripe on the thorax is diagnostic.

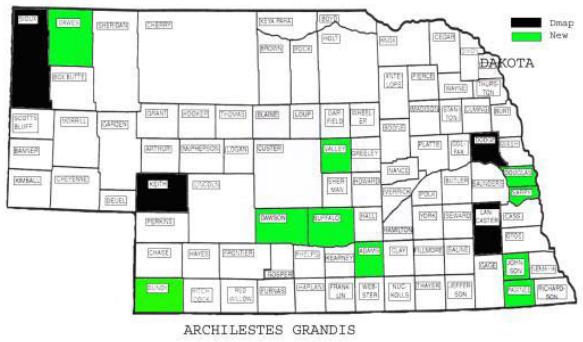

Rare. Nebraska is near the northern limit of this

uncommon and late season transcontinental species. The distribution is spotty with limited county records, and it is often present at a site one year and absent the next. However, it is frequently common or even abundant where collected. At Heron Haven (Douglas County) and Fontenelle Forest (Sarpy County) it is present most years. On July 4, 2012, a number were found in early July at a small drying wildlife pond in Pawnee County, an exceptionally early date. It is found along small sluggish streams and small ponds, where it is usually conspicuously perched and active. The limited records might be due to the late flight season and minimal collecting at that time, but we feel the spotty distribution is real as we have only added one county record in two late season trips.

Lestes - Pond Spreadwings: The seven species in this genus are wetland species and normally difficult to find. $L$. unguiculatus is the most common and to be expected in every county. Two other species, $L$. australis and $L$. rectangularis, are fairly common while the others are uncommon to rare and mainly restricted to the northern or western counties. L. rectangularis is the most distinctive, with a much longer abdomen than the other species. L. australis, $L$. disjunctus and $L$. forcipatus are very similar and usually require capture and examination of terminal appendages with a hand lens. 


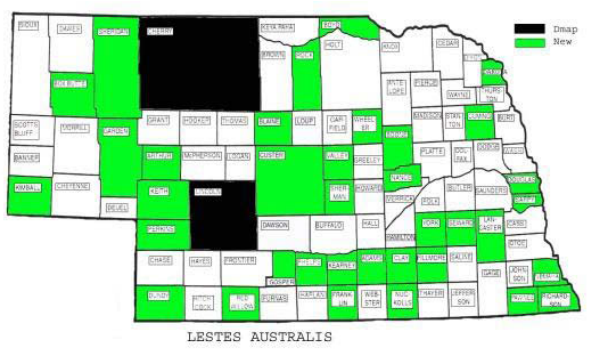

\section{Lestes australis (Southern Spreadwing)}

CR: 38, TL 36-46mm, Spec: 1908, Pub: Pruess, 1967

FP: early May to mid-September

Fairly common. This is an eastern species with Nebraska representing the northwestern edge of the range. There are two recent county records from eastern Wyoming. It is locally abundant and present in a variety of pond and marsh situations. This species appears earlier in the Spring than other members of the genus and is active into mid-summer. See discussion in Appendix $\mathrm{C}$ of the problems in distinguishing it from disjunctus. The spotty distribution across Nebraska may reflect the rarity of good Lestes habitat.

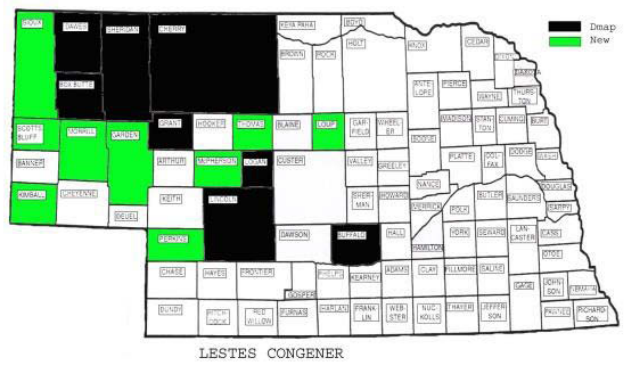

\section{Lestes congener (Spotted Spreadwing)}

CR: 17, TL: 33-42mm, Spec: 1951 (IORI), Pub: Kormondy, 1957

FP: late June to mid-October

Uncommon. This is a transcontinental species with records south to Alabama in the east and Arizona in the west, but there is a gap between central Nebraska and eastern lowa that closes as one goes north into southern SD and northern IA. The species' distribution is spotty in Nebraska and limited to the western half of the state, where it is frequently found in alkali situations and seasonal ponds. On July 11, 2012, they were abundant and the only odonate in drying puddles between the railroad and highway west of Lakeside, Sheridan County. These ponds had a thin border of tall cattails and a limited amount of open water. On July 15, 2011, a shallow flooded area between the road and the railroad near Whitney Lake, Dawes County, had hundreds of pairs, but was totally dry the next 2 years.

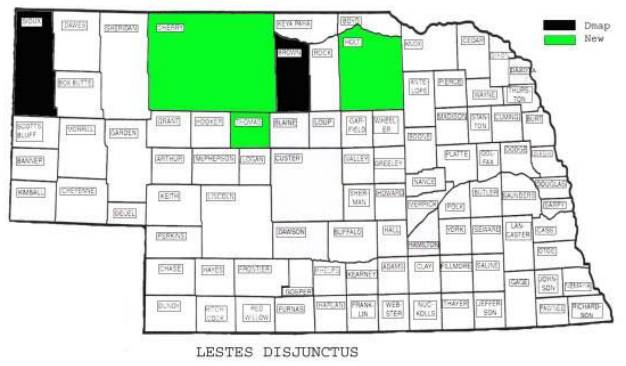

\section{Lestes disjunctus (Northern Spreadwing)}

CR: 5, TL: 33-42mm, Spec: 1969, Pub: Sibley, 2014a

FP: early to late July

Uncommon. This is a transcontinental species occurring mostly north of Nebraska. Our only encounter with the species was in Thomas County west of Halsey in dense reeds/cattails around a small fishing pond on July 9, 2012. The Nebraska records are restricted to northern counties but in the same habitat as $L$. australis. $L$. disjunctus emerges later in the year than $L$. australis but there is an overlap of the flight periods. There are records of $L$. australis from several northern counties, and in Sheridan County they were abundant at Smith Lake, but there 
seem to be no records of the two present in the same marsh. The southern Nebraska Dot Map records in Odonata Central as L. disjunctus are actually L. australis. (See Appendix C).

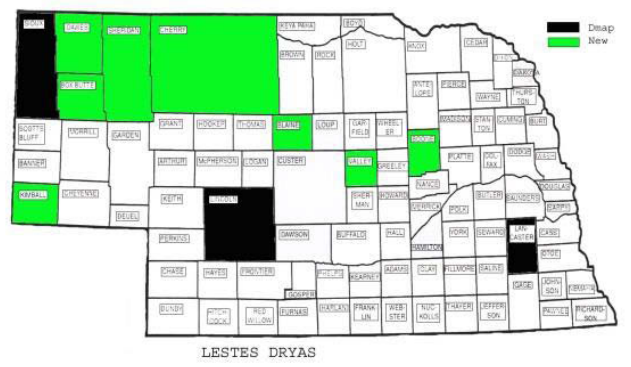

\section{Lestes dryas (Emerald Spreadwing)}

CR: 11, TL: 33-38mm, Spec: 1952, Pub: Pruess, 1967

FP: early June to late July

Rare. Nebraska is on the southern edge of the range of this transcontinental species, with no records south of Nebraska or lowa. The records of this species are mainly from northwestern counties with scattered records farther east. The few records are all from marsh areas, usually with permanent water and often near rivers or large lakes. In Valley County a small permanent (?) wet area with extensive areas of short reeds just east of Ord had L. australis, L. dryas, $L$. rectangularis and L. unguiculatus on July 7, 2008. Keech (1934) lists one 1912 specimen but this is a misidentified L. unguiculatus. There are no specimens in the UNSM collection prior to 1952.

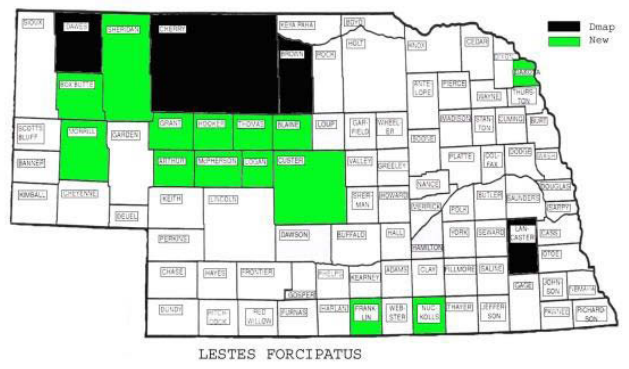

\section{Lestes forcipatus (Sweetflag Spreadwing)}

CR: 18, TL: 36-42mm, Spec: 1955 (see pub.), Pub: Kormondy, 1957

FP: late June to late July

Uncommon. This is a transcontinental species but most populations are eastern. A broad east-west band across lowa, Nebraska, southern South Dakota, eastern Colorado and eastern Wyoming connects the eastern populations to the more western populations. Most records are from the northern and western half of the state, where it usually occurs in small numbers in seasonal, cattail-lined ponds. In the vegetation around Ambler Lake, a few miles W of Stapleton in Logan County, it was super abundant on July 3, 2009, and mixed with L. congener and L. unguiculatus. Keech's (1934) 5 specimens from Lancaster Co. are misidentified L. australis. There are no pre-1997 specimens of $L$. forcipatus in the UNSM and the Dot Map record from Lancaster Co. may be in error (from Keech, 1934).

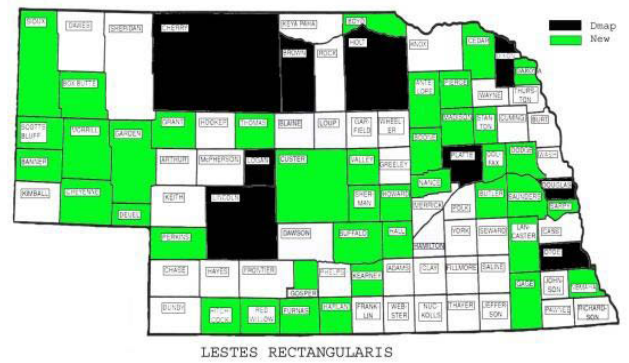

\section{Lestes rectangularis (Slender Spreadwing)}

CR: 49, TL: 42-53mm, Spec: 1913, Pub: Keech, 1934

FP: mid-June to late Aug.

Fairly common. This eastern species reaches its NW limits in NW Nebraska but is probably present, even if 
uncommon, in most counties of the state. In Gosper County it was common in deep grass on the steep banks of a small, heavily shaded stagnant stream (Elk Creek, 8 miles $\mathrm{N}$ of Arapahoe, July 16, 2005), but most of our county records are of one or a few individuals. The normal habitat is the edge of stagnant streams, ditches or small drying ponds and disproportionally in brushy vegetation just back from these areas.

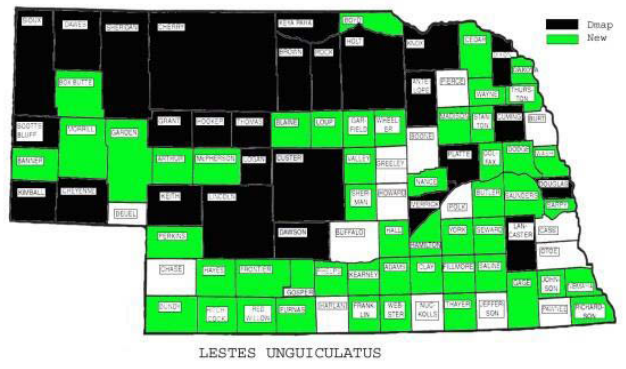

\section{Lestes unguiculatus (Lyre-tipped Spreadwing)}

CR: 78, TL: 33-41mm, Spec: 1888, Pub: Keech, 1934

FP: early June to early October

Common. This transcontinental species is the most common spreadwing in Nebraska and is found in a great variety of marshy areas, pond edges or even formerly wet depressions. It is most common in reeds, grass, or other vegetation back from the pond edge, but at cattle ponds with flooded weeds it may be conspicuous on isolated stems at the edge of the water. It usually flies low over the water and often within the vegetation. In Blaine County it was abundant in short dense reeds around a shallow, almost dry natural depression in Sandhills pasture just south of Brewster on July 18, 2005.

Coenagrionidae - Pond Damsels: Most of the Nebraska damselfly species are included in the six genera and thirty-six species of this family. They are pond and stream inhabitants and represent most of the damselflies the casual observer will be familiar with. Most are smaller $(20-40 \mathrm{~mm})$ than any member of the other two damselfly families and are varied in coloration, behavior and habitat.

Three genera, Argia (mainly stream species), Enallagma (mainly pond species), and Ischnura (in marshy areas of any wetland) have numerous species. And three genera, Amphiagrion (widespread), Coenagrion (one record), and Nehalennia (rare), are represented by single species.

Amphiagrion - Red Damsel: Amphiagrion is a distinctive, small, red, short-bodied species which is easily separated from other adult damselflies. It is a species of seeps and small, very shallow, clear flowing streams.

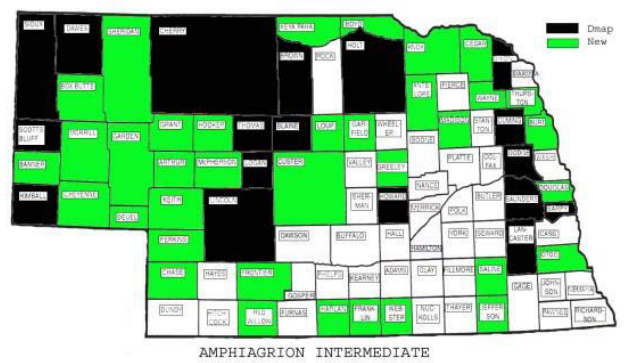

AMPHIAGRION INTERMEDIATE

\section{Amphiagrion saucium/abbreviatum (Eastern/Western Red Damsel)}

CR: 54, TL 23-27mm, Spec: 1888, Pub: Keech, 1934 (as saucium)

FP: mid-May to late August 
Common. The genus is transcontinental, but individuals in the eastern (A. saucium) and western (A. abbreviatum) United States, are easily separated and regarded as full species. The ones in Nebraska and much of the Midwest are intermediate, and Nebraska is on the western edge of the intermediate zone. A typical habitat would be a seepage area where there is a permanent, very shallow flow of clear water through open to fairly dense stands of aquatic vegetation. Good sites for the species are the seepages at the bases of dams and seepage areas at the edge of streams or even rivers. It is local but widespread in Nebraska, although rarer in the eastern and southern half of the state, and evidently opportunistic in inhabiting new areas. In Perkins County the only habitat found, shared with Sympetrum, was a short stretch of hillside seepage caused by a grey water flow from a small café, but there was a good number of individuals on June 25, 2010.

The name $A$. mesonum was proposed for the intermediate Midwestern specimens and several museums have specimens labeled as paratypes of $A$. mesonum. This name was never published and there seems to be no suite of characters that would identify these intermediate populations. Most of the Nebraska specimens do not fit either A. abbreviatum or A. saucium.

Argia - Dancers: There are ten species of Argia recorded in the state but it seems likely others will spread here or occur as accidentals. There is an isolated population of the Southwestern species $A$. immunda (Kiowa Dancer) in the Black Hills and in an extremely wet year these could show up in Sioux or Dawes Counties. Small streams to large rivers are the preferred habitats for this genus but several species are also common on ponds and lakes. Many are blue in color causing initial confusion with Enallagma (Bluets). Identification can be difficult, but with practice, most males can be identified in the field. Argia plana and A. vivida must be netted and examined under a microscope, and many other species should be netted and sight identification confirmed with a hand lens.

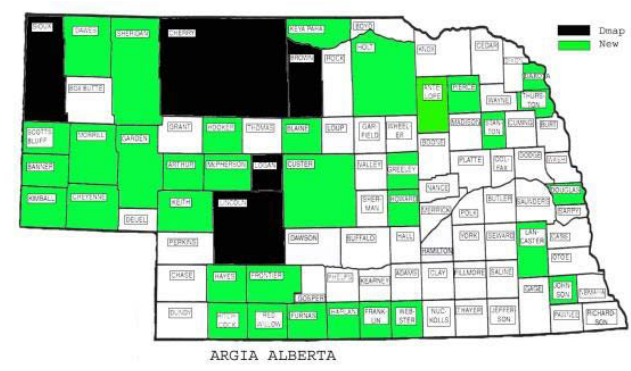

\section{Argia alberta (Paiute Dancer)}

CR: 39, TL: 27-32mm, Spec: 1964, Pub: Pruess, 1967

FP: mid-May to late August

Fairly common. A western species with northwest lowa representing the northeast edge of the range. It is most common in the western twothirds of the state with scattered records in the eastern counties. It is found in a large variety of habitats: seeps, small, muddy or sandy streams, marshy areas and even in long grass hanging into streams and small rivers. Below the dam at Harlan County Reservoir it was common at seeps running into the Republican River on July 13, 2005, and August 31, 2013. Two miles south of Lodgepole, Cheyenne County, it was common July 19, 2011, "along a tiny stream completely overhung with grass." 


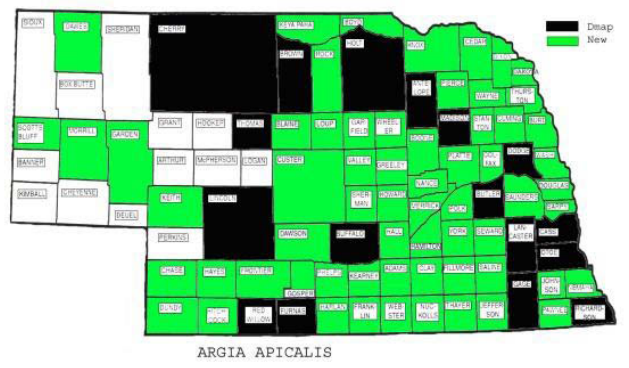

\section{Argia apicalis (Blue-fronted Dancer)}

CR: 80, TL: 33-40mm, Spec: 1912, Pub: Keech, 1934

FP: late May to early September

Our most common Argia. This is an eastern species with Nebraska near the western edge of the range (there are only a few records in eastern Colorado, eastern Wyoming and Montana and the Black Hills of South Dakota). It is abundant and widespread in the eastern two-thirds of the state, but unrecorded from a number of Sandhills counties without streams or rivers. In the Panhandle it is present only in counties bordering the North Platte River or in Dawes County on tributaries of the White River. This species is typically found on a variety of streams and rivers, and in the eastern quarter to half of Nebraska it is also abundant on ponds and lakes, mixing with the abundant Enallagma civile (Familiar Bluet). When cold or paired, the bright blue of the thorax will look black, making one think of $A$. tibialis (Blue-tipped Dancer). The 4-fold increase in records from 2004 is probably due to increased collecting rather than recent range expansions.

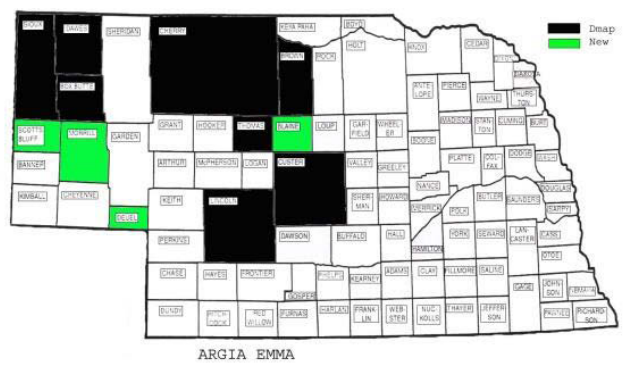

\section{Argia emma (Emma's Dancer)}

CR: 12, TL: 33-39mm, Spec: 1952, Pub: Pruess, 1967

FP: late June to mid-August

Uncommon. This western species reaches the extreme eastern edge of its range in central Nebraska (Brown and Custer Counties). There is one record in central lowa. This species is found in the grassy edges of clear, sandy rivers or large streams and there are only scattered records through its Nebraska range. On a tributary stream of the Niobrara River at the Sioux/Box Butte County line it was noted as "fairly common along a small, muddy, grass-lined stream through pasture" July 21, 2006. On the same day at Riverside Park, Scotts Bluff County, a "small number were still out along the edge of the North Platte River at 6 PM."

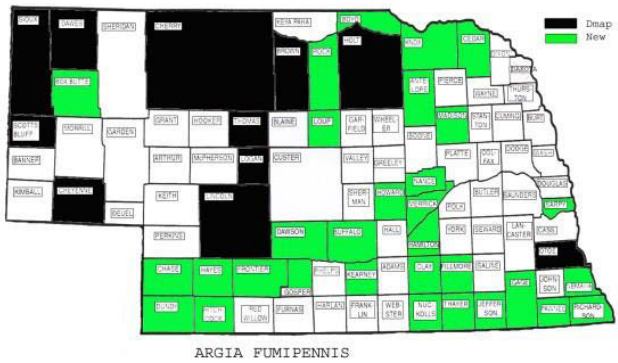

\section{Argia fumipennis (Variable Dancer)}

CR: 42, TL: 29-33mm, Spec: 1912, Pub: Keech, 1934

FP: mid-June to late August

Fairly common. The Nebraska/Wyoming line is near the western limit and Nebraska is at the northern limit of the range for this eastern species. Although widespread in the state, it is rare in counties along the eastern edge of the state and more common in the southern and northern 
border counties than in the center of the state. It seems equally at home on ponds, streams and rivers and will be found in the edge vegetation or even resting on the sandy or muddy banks.

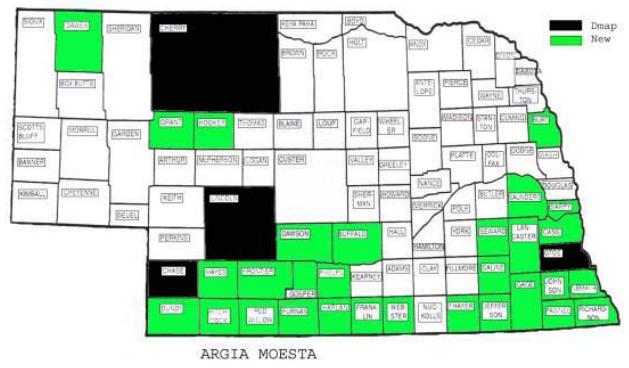

\section{Argia moesta (Powdered Dancer)}

CR: 34, TL: 37-42mm, Spec: 1963, Pub: Pruess, 1967

FP: early June to early September

Fairly common. This is another eastern species with Nebraska near the northwest edge of its range.

Although primarily a river species, it is found on streams in southeastern counties and on large reservoirs on the Republican River. Recent records from the Black Hills and Wyoming may reflect either a recent invasion or poor historic coverage. Most records are from the southern tiers of counties, but there are also records from the upper reaches of the Niobrara and Loup Rivers in Cherry, Grant and Hooker Counties, plus records in Dawes County on the White River. This is a large conspicuous species, but we have not found it on the lower stretches of the Niobrara and Loup Rivers. The absence on the North Platte River through the Panhandle also seems strange as moesta is common on the tributaries in Wyoming not many miles west. This species has a decided preference for riffle areas of streams and bare rock rip rap around bridge abutments and is often common where found. On the Republican River it was very uncommon except behind the dams at Harlan County Reservoir and Enders Reservoir, seeming to prefer the lake to the river in this instance.

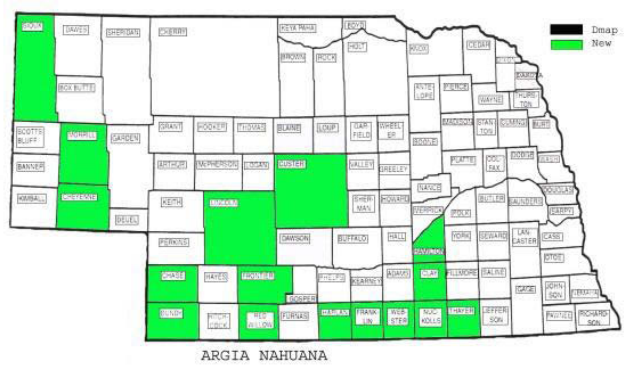

\section{Argia nahuana (Aztec Dancer)}

CR: 16, TL: 28-35mm, Spec: 1964, Pub: Sibley, $2006 a$

FP: late June to mid-August

Uncommon. This western and southern species reaches its northern limits in Nebraska. There is one record from Sioux County (White River near Glen) in the extreme northwest portion of the state, but otherwise the species is restricted to more southern counties. It is found mainly on small, clear, sandy or muddy streams through pasture areas and occasionally on ponds associated with such streams. It is occasionally common but there are usually just a few individuals. The first specimen was collected in Lincoln County in 1964 but was not identified before a second specimen was collected in 2006. There are now records from 16 counties but the species was probably always present and just overlooked. 


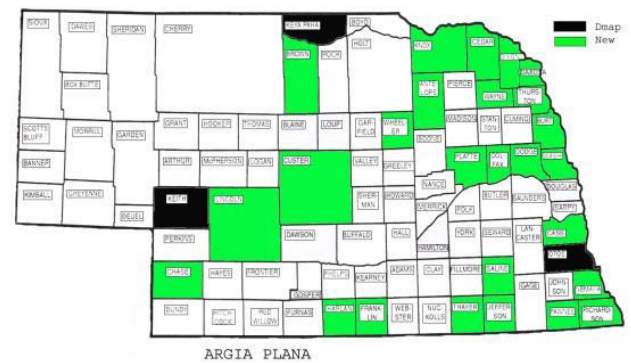

ARGIA PLANA

\section{Argia plana (Springwater Dancer)}

CR: 29, TL: 34-40mm, Spec: 1963, Pub: Beckemeyer, $1998 b$

FP: late May to mid-October

Fairly common. This mid-western species extends west into Nebraska and north into the southeastern counties of South Dakota with the western edge of range marked in Nebraska by a diagonal running from the north (Keya Paha and Brown Counties) to the southwest (Keith and Chase Counties). It is found primarily in seepage areas or on small clear streams with overhanging grass and only occasionally on clear, fast flowing streams. It is very difficult to separate from $A$. vivida, but the ranges barely overlap in Brown and Keya Paha Counties. The Dot Map record from Cherry County is actually A. vivida and Dot Map records from the Black Hills (Fall River and Custer County) are also A. vivida. Several guides mention the presence or absence of a black basal spot on the 3rd segment as a help in separating the two species. However this character, almost $100 \%$ reliable in California, only separates about $70 \%$ of specimens we have collected in Nebraska (see A. vivida).

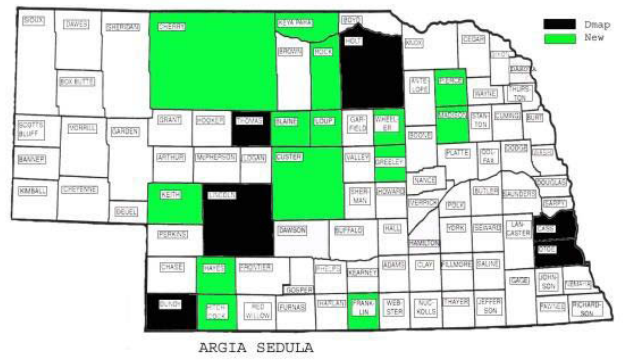

\section{Argia sedula (Blue-ringed Dancer)}

CR: 20, TL: 29-34mm, Spec: 1913, Pub: Pruess, 1967

FP: early July to late August

Uncommon. This is a transsouthern species but Nebraska is at the northern extension of the range in the Midwest. There are no Wyoming, lowa or South Dakota records, and Nebraska records are located in a band running north-south through the center of the state (Dundy and Franklin Counties in the south to Cherry and Holt Counties in the north) plus two disjunct records, Cass and Otoe Counties on the Missouri River, and two, Pierce and Madison Counties, just east of the main range. It is rarely common and is found on rivers and streams down to those so small the grass on both sides touches in the middle. My notes often mention "in dense grass hanging into water".

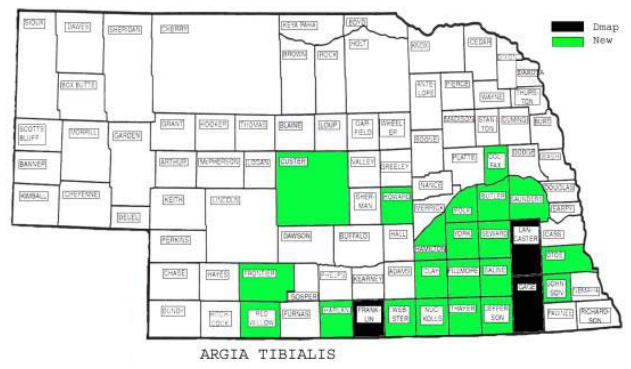

\section{Argia tibialis (Blue-tipped Dancer)}

CR: 24, TL: 30-38mm, Spec: 1912, Pub: Keech, 1934

FP: early June to late July

Fairly common. This eastern species is found in the 
eastern and southern half of the state. It was overlooked on early trips and thought to be rare to uncommon until we realized it was almost inevitably found where there were log or brush tangles in the stream and we only had to separate it from the larger, brighter, less skittish, and excessively abundant $A$. apicalis. Even in their preferred sites among logs across a stream, $A$. tibialis are rarely common. An exception was found in Saline County where the species was the most common damsel on June 23, 2009, along a small tributary to the Big Blue River southeast of Wilber. The stream here was shallow, clogged with fallen trees and heavily shaded.

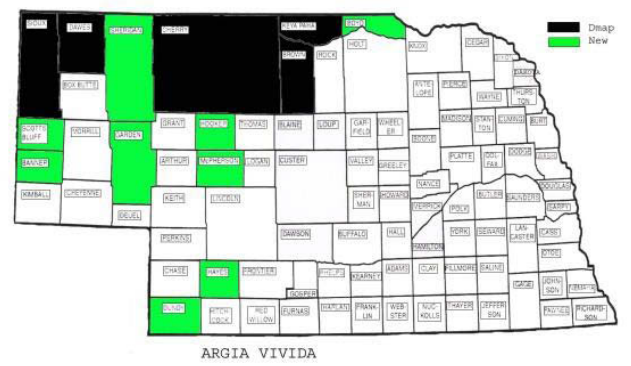

\section{Argia vivida (Vivid Dancer)}

CR: 14, TL: 29-38mm, Spec: 1905, Pub: Keech, 1934

FP: late May to late August

Uncommon (see A. plana). This is a western species with Nebraska at the extreme eastern edge of the range. It is found only in the western half of Nebraska east to Boyd and Hayes Counties in the same habitat as $A$. plana - small streams, seeps, rushing, clear, sandy streams. It is often abundant and the dominate damsel where found but is impossible to separate from $A$. plana in the field and often confusing in the hand. Every collection examined has contained misidentified specimens of $A$. plana or $A$. vivida.

Coenagrion - Bluet: Very similar to Enallagma but only one Nebraska record.

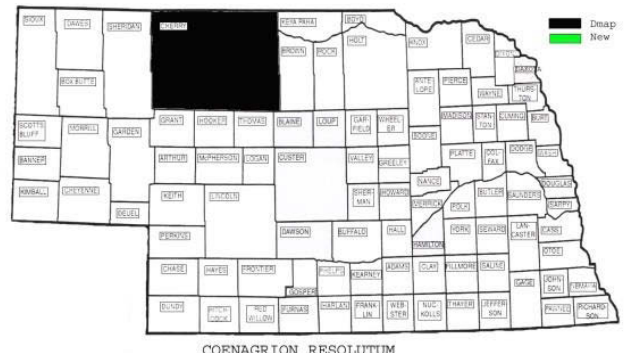

COENAGRION RESOLUTUM

\section{Coenagrion resolutum (Taiga Bluet)}

CR: 1, TL: 27-33mm, Spec: 1971 (IORI), Pub: Bick \& Hornuff, 1972

Accidental. This is a northern species with northern Nebraska at the southern edge of the range. There is only one record, which is surprising, as there are several records in northwest lowa. It is found in sedge marshes and is easily overlooked as it looks like an Enallagma. The only record is a male collected by G.H. Bick on June 24, 1971, in a small marshy roadside pond 15 miles southeast of Valentine.

Enallagma - American Bluets: The typical species is blue and a pond inhabitant, although several species are equally common on streams or rivers and a few are found primarily there E. anna (River Bluet) and E. exsulans (Stream Bluet). The 17 species recorded in Nebraska include colors other than blue: E. signatum (Orange Bluet) is a distinctive orange and mostly a late afternoon species, E.vesperum (Vesper Bluet) is a distinctive yellow and a mostly aftersunset species, E. antennatum (Rainbow Bluet) has a yellow nose and distinctive pattern. WITH PRACTICE, most males can be separated in the field, but several very common species $-E$. 
carunculatum (Tule Bluet), E.civile (Common Bluet), and E. hageni (Hagen's Bluet) - have almost the same blue/black abdominal pattern.

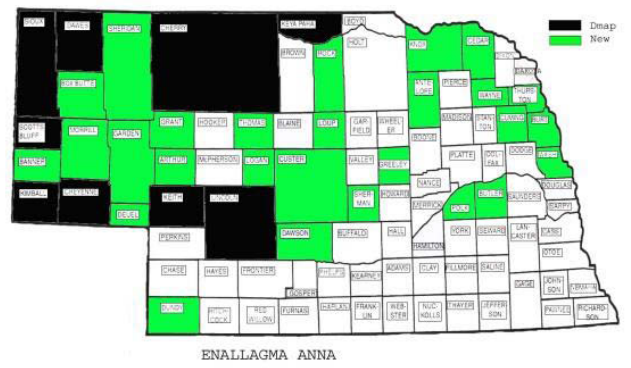

\section{Enallagma anna (River Bluet)}

CR: 36, TL: 29-36mm, Spec: 1905, Pub: Keech, 1934

FP: late May to late August

Fairly common. This western species is common in lowa, with scattered records farther east and scattered records in southern South Dakota. All these records are an eastern projection, as the species is not found south of Nebraska or north of southern South Dakota. It is nearly statewide in Nebraska, although absent from the southern counties, and this absence is more pronounced to the east. It is found in a great variety of small streams, even drainage ditches, and occasionally in ponds. In the eastern counties it is frequently found in streams with E. civile.

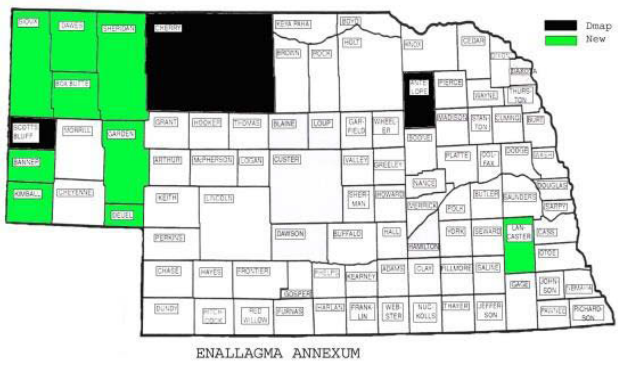

\section{Enallagma annexum (Northern Bluet)}

CR: 12, TL: 29-40mm, Spec: 1912, Pub: Keech, 1934

FP: early June to mid-July.

Rare. The mid-western gap in the range of this transcontinental species extends north well into North Dakota and as a result, there are only two records in the eastern counties of Nebraska. The species is common in southeastern South Dakota and western lowa but absent across most of South Dakota. The Nebraska records from Antelope and Lancaster counties presumably are linked to the eastern population and not to the individuals found in the Panhandle. This is a typical pond species found in edge vegetation and an early season species. At the latest date, July 19, only one was found at a pond dominated by E. carunculatum. In Banner County on July $13,2011, E$. annexum was the dominate species (a few E. boreale) at a small pond at the junction between grasslands and cedar. On July $21,2006, E$. carunculatum was the dominate species, at the same pond with $E$. civile also present and common, but no E. annexum.

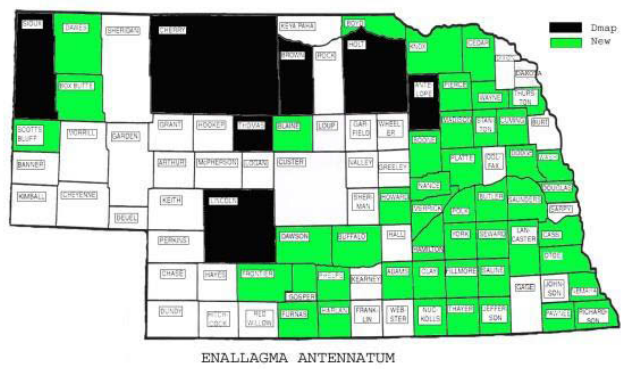

Enallagma antennatum (Rainbow Bluet)

CR: 54, TL: 27-31mm, Spec: 1915, Pub: Keech, 1934

FP: mid-May to late July

Common. This eastern species is common in the 
eastern half of the state and in northern counties to Wyoming, but there are only a few records in eastern Wyoming. It seems equally likely at ponds or small, clear streams, and even irrigation ditches. Both males and females are distinctively colored and patterned. This species may be increasing in abundance and extending its range west. This is a conspicuous species but it had only been recorded in 8 counties before the survey started. In 2005 and 2006 it was found in an additional 30 , and in 18 more counties in the last 8 years of the survey.

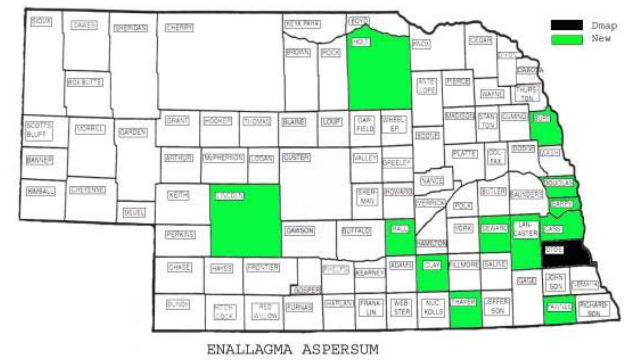

ENALLAGMA ASPERSUM

\section{Enallagma aspersum (Azure Bluet)}

CR: 13, TL: 26-34mm, Spec: 1998 (G. Harp), Pub: Beckemeyer 1998b

FP: mid-June to early September has only been recorded in the eastern half of the state. It was first recorded July 21, 1998, by G. Harp at Arbor Day Farm in Nebraska City, and there have been scattered records since. We have collected it at 12 other sites in Nebraska and 11 of these were seasonal and fishless. At the other site we found only one individual, and that was well away from the water. A fairly typical site was a small fishless, seasonal, cattail-lined pond in a hayfield (Holt Co. just south of the Niobrara River). On July 26, 2013, both E. annexum and E. hageni were abundant, with some teneral Sympetrum (meadowhawks) and both species of Celithemis (pennants). The species is probably under-collected, as the best sites are rarely attractive collecting venues, supporting only a limited number of species.

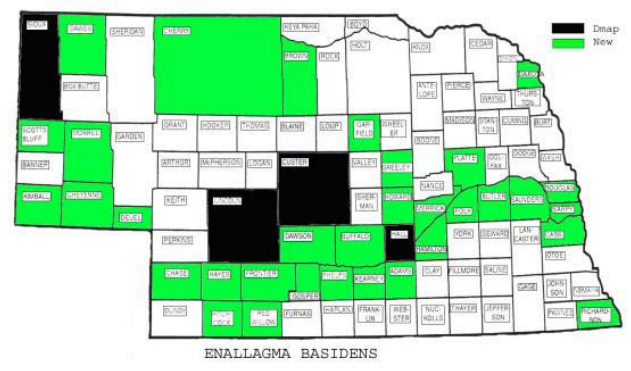

\section{Enallagma basidens (Double-striped Bluet)}

CR: 37, TL: 21-28mm, Spec: 1963, Pub: Pruess, 1967

FP: early June to early September

Fairly common. The range of this eastern species extends to western Nebraska, eastern Colorado and eastern Wyoming, and Nebraska is at the northern edge of the range. It has a long flight season and is most frequently found in small ponds but can also be present in clear flowing streams. Evidently more tolerant of lower oxygen levels than most Enallagma, it is frequently found in minimally vegetated borrow pits with $E$. civile. The large number of borrow pits created in building I-80 may have accelerated the spread of the species across the state. Almost every county along the Platte River has this species (a correlation with borrow pits?). It is often found with the much more abundant $E$. civile and despite $E$. basidens' smaller size and distinctive thoracic pattern, it can be easily overlooked. 


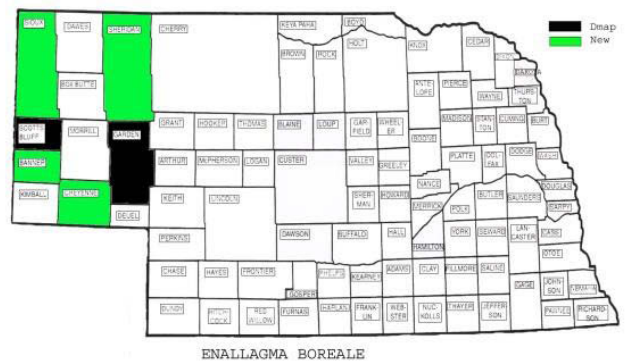

\section{Enallagma boreale (Boreal Bluet)}

CR: 6, TL: 28-36mm, Spec: 1913, Pub: Keech, 1934

FP: mid-June to early September

Rare. This northern transcontinental species is recorded in Nebraska only in the Panhandle (6 of 11 counties), and it is rare in northern lowa. The species is at its southern limit in northern lowa but west of Nebraska the range extends south into New Mexico. The mid-western gap in the Nebraska range extends into North Dakota. We have rarely encountered it, but at Buffalo Creek WMA, Banner and Scotts Bluff Counties, on July 13, 2011, and at Winters Creek Lake, Scotts Bluff County, on July 12, 2011, it was very common. It is usually found in vegetation at or just back from the edge of lakes or ponds. The Dot Map and Odonata Central record (OC\# 173597) from Lancaster County is a misidentified E. annexum collected June 21, 1912, (OC\# 411226).

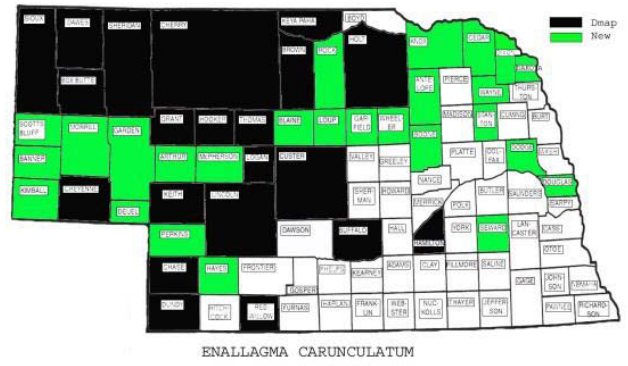

\section{Enallagma carunculatum (Tule Bluet)}

CR: 47, TL: 26-35mm, Spec: 1913, Pub: Keech, 1934

FP: early June to late September

Common. This transcontinental species is common in lowa and in the western counties of Nebraska but is less and less common as one goes east in Nebraska and is certainly rare, if not absent, from many southeastern counties. It is difficult to separate in the field from E. civile and shares the same habitat. In eastern Nebraska $E$. civile is always the more common species, while $E$. carunculatum becomes more common as one goes west, until it is often the dominate bluet in a pond, lake or stream. In the western counties $E$. civile continues to dominate in new or basically sterile ponds while $E$. carunculatum is the expected species in more permanent ponds. At Lane Lake, Sheridan County, on July 11, 2012, and at Whitney Lake, Dawes County, on July 13,2012 , it was the only other Enallagma found in these alkali lakes with E. clausum.

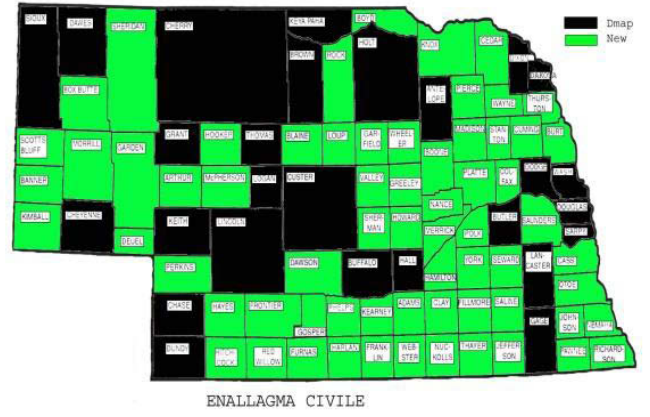

\section{Enallagma civile (Familiar Bluet)}

CR: 93, TL: 30-39mm, Spec: 1899, Pub: Keech, 1934

FP: early May to early October

Very common. This transcontinental species is the most abundant and widespread bluet in Nebraska. It is less common as one goes west although still abundant locally. In the eastern counties it is as common on streams as it is in lakes, but in western counties it is mostly restricted to the edge vegetation of ponds and lakes. It can be the 
only bluet, and one of only a few species, on new, polluted or seasonal ponds and particularly borrow pits with low oxygen levels, where it is often abundant.

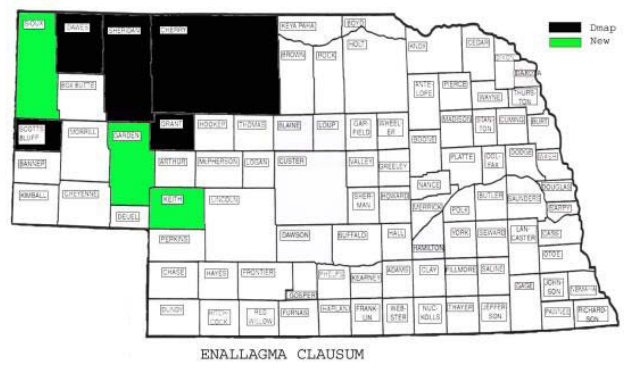

\section{Enallagma clausum (Alkali Bluet)}

CR: 8, TL: 28-37mm, Spec: 1915, Pub: Keech, 1934

FP: early June to late July

Rare. This is a western species reaching eastern North Dakota, South Dakota and western Nebraska, with scattered records almost to Maine. In Nebraska it is recorded in only the western third of the state, and primarily in the northwest corner. It is typically associated with alkali situations, where it may be abundant. At the very alkali Lane Lake in Sheridan County on July 11, 2012, it was abundant in the thin reeds around edge of the lake and the fairly common $E$. carunculatum was the only other odonate present. At Smith Lake, Sheridan County, on July 16, 2011, and Box Butte Reservoir, Dawes County, on July 11, 2012, it was also abundant, although these lakes are not alkali.

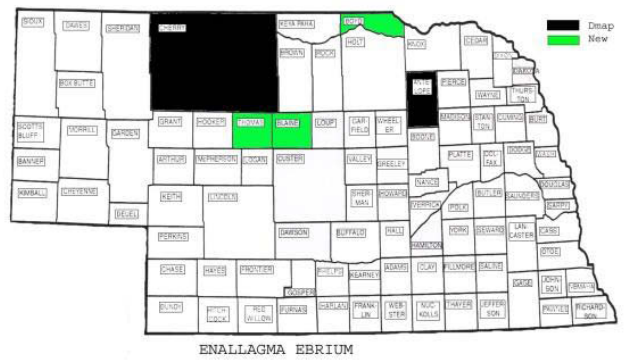

\section{Enallagma ebrium (Marsh Bluet)}

CR: 5, TL: 28-33mm, Spec: 1915, Pub: Keech, 1934

FP: late June to mid-July

Rare. This transcontinental species is found in five northern Nebraska counties at the southern edge of its range. The typical habitat, in Nebraska, is a small marshy pond and all records have been of just a few individuals. We have collected it twice - near Thedford, Thomas County, on July 9 , 2012, and near Lynch Bridge, Boyd County, on July 3, 2008. Only one was collected at the 1998 DSA meeting, July 19, 1998, near the junction of the Niobrara River and Minnechaduza Creek in Valentine. This attests to its rarity, as the area was visited by a large number of attendees. The only other records are a 1915 record from Neligh, Antelope County, and a George Bick record near Brewster, Blaine County, on July 18, 1969.

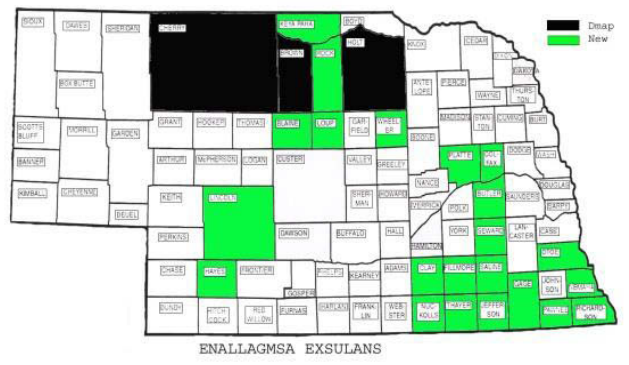

\section{Enallagma exsulans (Stream Bluet)}

CR: 25, TL: 30-37mm, Spec: 1964, Pub: Pruess, 1967

FP: late May to mid-August

Usually uncommon. This is an eastern species of small, clear sandy streams, reaching its extreme western limit in Nebraska and the Black Hills of South Dakota. Most records are from the 
southeast counties and Sandhills. Since it is abundant in the Black Hills, it is hard to explain its absence in similar streams in Dawes and Sioux counties just to the south. Although normally just one or a few individuals were seen along small sandy streams, we found it abundant along a side stream off the Platte River, Platte County, on June 30, 2006, and on Bloody Creek, at the Loup and Rock County line, on July 20, 2005.

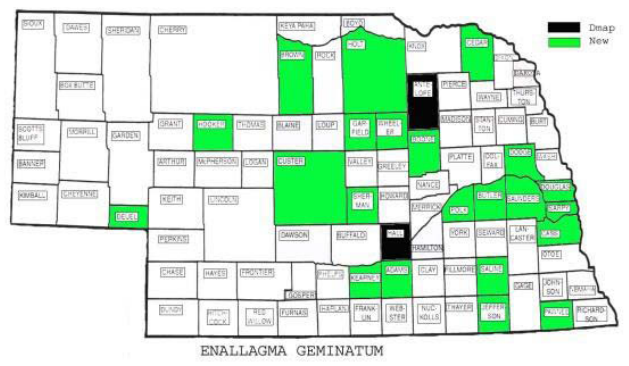

\section{Enallagma geminatum (Skimming Bluet)}

CR: 24, TL: 22-28mm, Spec: 1909, Pub: Pruess, 1967

FP: late May to early September

Uncommon. This eastern species is found in about one third of the counties in the eastern half of Nebraska. There are only two records (Hooker and Deuel Counties) west of the center of the state. It is found in borrow pit ponds, weedy coves on lakes, and a variety of similar pond habitats, frequently on lily pads. Usually only a few individuals were seen but it was common at Bowman Lake, Sherman County, on June 9, 2013, and abundant at Goose Lake WMA, Holt County, on May 22, 2012.

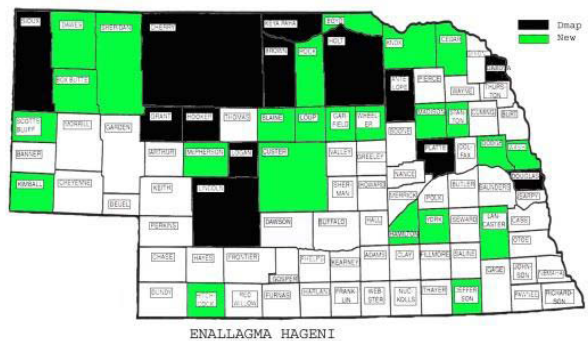

Enallagma hageni (Hagen's Bluet)

CR: 37, TL: 26-32mm, Spec: 1902, Pub: Keech, 1934

FP: late May to mid-August

Fairly common. This transcontinental species is at the southern and western edge of its range in Nebraska. It is widespread in the state but absent, with two exceptions, from the southern two rows of counties, and there are no records in Kansas. We have found it very common only at one pond. One of the many ponds in Fremont Lakes SRA, Dodge County, July 9, 2009, where it was the dominant Enallagma. Elsewhere it has never been found in numbers and is often back in the grass away from the water and other more abundant Enallagma. It is easily confused with the much more numerous $E$. civile and E. carunculatum, but this is unlikely to account for the limited number of records of this pond species.

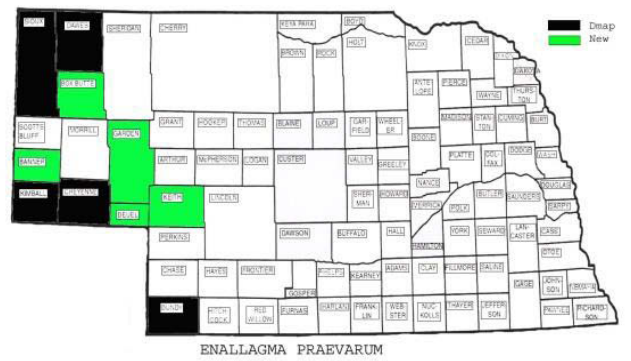

\section{Enallagma praevarum (Arroyo Bluet)}

CR: 10, TL: 27-34mm, Spec: 1910, Pub: Keech, 1934

FP: early July to early September

Uncommon. This is a western species extending just past the Panhandle to Keith and Dundy Counties in 
the southwest part of state. We found it common only in the southwest corner of the Panhandle - on July 7, 2011, west of Kimball (Lodgepole Creek - as a small, sandy creek through wet meadows) and in Cheyenne County on July 19, 2011, near Sunol, (Lodgepole Creek - as a small sluggish stream through pasture). There are about as many records from clear streams as from sluggish streams and almost stagnant ponds. It is easily confused with $E$. anna.

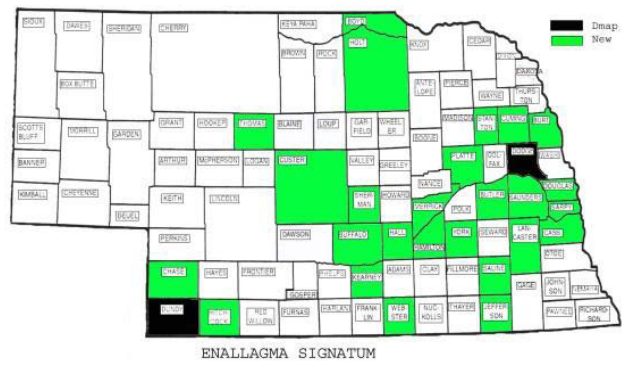

\section{Enallagma signatum (Orange Bluet)}

CR: 28, TL: 28-36mm, Spec: 1963 (IORI), Pub:

Beckemeyer, 1998b

FP: early June to early September

Fairly common. This eastern species is at the western edge of its range in central and southwest Nebraska, with a number of extreme western records in Colorado. This is a pond and lake species usually not active until late afternoon or even evening. At that time, it may suddenly become abundant on a pond where it was absent two hours earlier. It is certainly more widespread than the records indicate, as finding it often requires a special trip at dusk. At Maskenthine Lake, Stanton County, it was common during the day June 26, 2008, but not so a few days later. At Alexandria Lake, Jefferson County, it was not out until after sunset July 6, 2005.

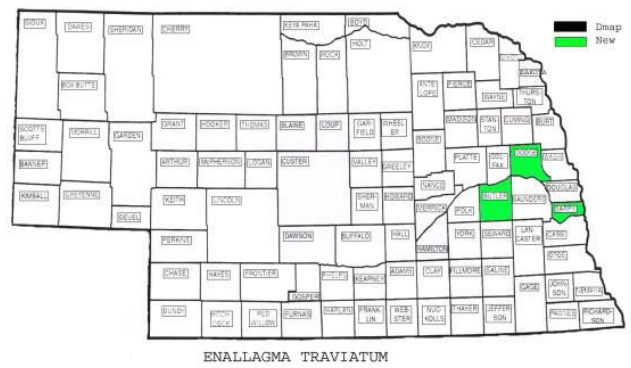

\section{Enallagma traviatum (Slender Bluet)}

CR: 3, TL: 28-32mm, Spec: 2006 (IORI), Pub: Sibley $2006 b$

FP: early July to early August

Rare. This eastern pond species is found in three eastern Nebraska counties at the western and northern edge of its range. The species was first reported from the Fontenelle Forest area, Sarpy County, by the Padelfords. The only additional records are of one laying eggs at Timber Point Lake, Butler County, on July 3, 2011, and numerous sightings at Fremont Lakes, Dodge County. It has been found on small lakes/large ponds in Nebraska and despite the limited county records, it can be super abundant. This species will fly on overcast days and even in light drizzle when other species of the genus are hiding. At the Fremont Lakes SRA, Dodge County, on July 9, 2009, the weather was overcast and drizzling at 9:30AM but there were hundreds of pairs flying or clinging to branches 3-8 feet above the water. No other damselflies were active at this time. 


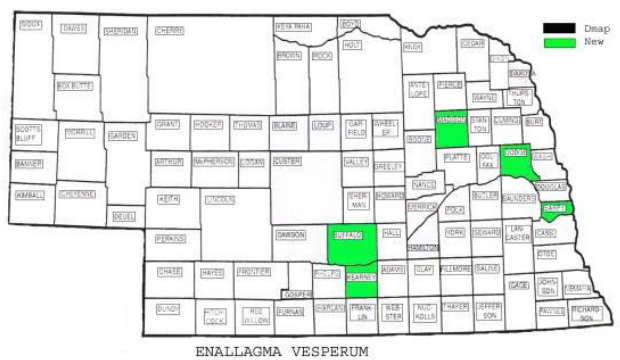

ENALLAGMA VESPERUM

\section{Enallagma vesperum (Vesper Bluet)}

CR: 5, TL: 29-38mm, Spec: 2008 (IORI), Pub: Sibley, $2011 a$

FP: late June to early July

Rare. This is an eastern species recorded to central Nebraska. Only an eastern Colorado record and one from western Kansas are farther west than the Buffalo/Kearney County records in central Nebraska. This is a late evening flier, often not out until well after sunset, and as a result, it is rarely collected and certainly more common and widespread than the records indicate. The best population, in our study, has been 150 miles into the state at Fort Kearny SRA in Buffalo and Kearney Counties at the swimming lake. There are other records from Dodge, Madison and Sarpy counties, all on ponds with well-vegetated edges. It can be flushed from trees in the vicinity of a pond during the day and on rare occasions will be active on ponds in mid-afternoon.

Ischnura - Forktails: All six Ischnura are found in marshy areas around ponds or slow streams or in seasonal wetlands. Of the species found in the eastern half of the state, I. hastata (Citrine Forktail) is the most distinctive, being straw yellow, and I.verticalis (Eastern Forktail) is the most widespread. The only other species you might find in the eastern half of the state are I. posita (Fragile Forktail), which is very secretive and rare, and I. barberi (Desert Forktail), which is only found around Lincoln in very saline situations. In the western counties, I. perparva (Western Forktail) and $I$. verticalis are almost identical, equally abundant and often in the same ponds. $I$. damula (Plains Forktail) is also abundant but easily separated by thoracic pattern. There are other species similar to I. damula close by in Kansas and Colorado but not yet found in Nebraska.

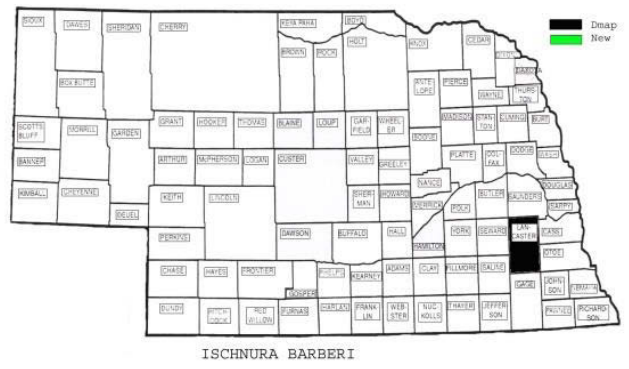

\section{Ischnura barberi (Desert Forktail)}

CR: 1, TL: 27-32mm, Spec: 1937 (USNM), Pub: Montgomery, 1967

FP: mid-May to mid-September.

Local. This southwestern species is found extralimitally in two southern Kansas counties and one eastern Nebraska county. The isolated population in Lancaster County, Nebraska, is at the northern and eastern limits of the range and 200 miles to the north and east of the isolated Kansas populations. The first record for Nebraska was a large population found in 1937 at Capitol Beach in Lincoln. The species was thought possibly extirpated in the 1990's (Beckemeyer, 1999c) but was collected in 2000 (Bedell, 2001). It has probably always been abundant at several sites in the city of Lincoln (Steve Spomer, pers. com). The best accessible site, Dakota Springs, is near exit 403 off I-80. This is the population Bedell reported on. The best site is where it was originally discovered. However, this 
site is the ditches along I-80 at Capitol Beach and no stopping is allowed on the interstate. All sites are associated with highly alkaline streams. At Dakota Springs, a tiny stream with very saline water flows in a deep ditch through grassy fields. Very few individuals of any other species are here but $I$. barberi is abundant. It is reported to be most common before July 1 and after Aug. 1, but some are present during this dry period. It has not been found at other saline sites in the state. Efforts by the state to save saline habitats along Salt Creek seem likely to produce a large increase in the present limited population.

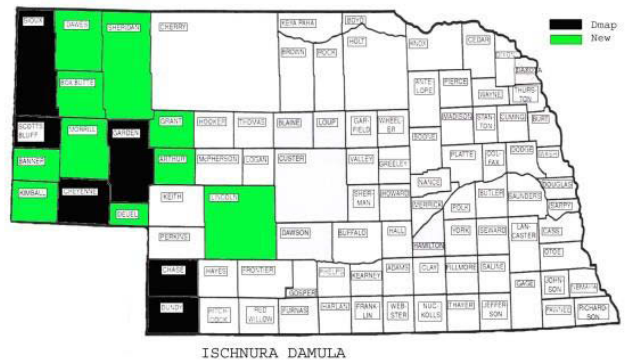

Ischnura damula (Plains Forktail)

CR: 16, TL: 23-34mm, Spec: 1915, Pub: Keech, 1934

FP: early June to early September

Common. This is a western species going way north into Canada and east to eastern North and South Dakota, but in Nebraska it is not found east of the western counties. It is regularly found in all the Panhandle Counties and also recorded from 5 counties just east of there. Most of these records are of just a few individuals and often in association with $I$. verticalis and $I$. perparva in marshy vegetation along small streams or ponds. When we have found it abundant [outflow from Oliver Reservoir (Kimball Co.), Chadron Creek (Dawes Co.), Pine Creek from Smith Lake (Sheridan Co.)], it has been associated with colder than average streams, either spring fed or coming from the bottom of a reservoir.

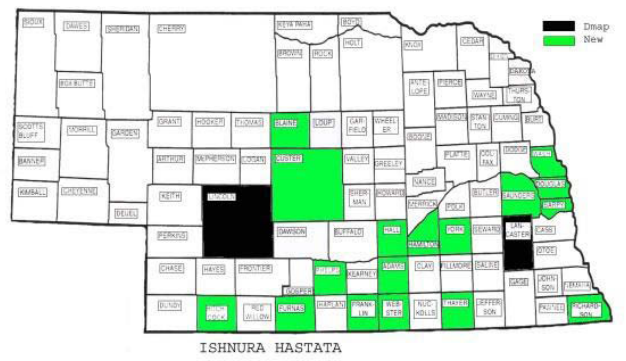

\section{Ischnura hastata (Citrine Forktail)}

CR: 19, TL: 20-25mm, Spec: 1998 (see pub.), Pub: Beckemeyer, 1998b

FP: late June to early September

Uncommon. This southern transcontinental species occurs in Nebraska at the extreme northern and western edge of its range. There are no records in the Dakotas and only one Colorado record. Nebraska records are from the southern half of the state west to Custer and Lincoln Counties. This tiny yellow species may be reliable and common for several years at some sites, but sporadic and rare at most. A large, shallow, marshy pond at Mormon Island SRA (Hall Co.) has been the most reliable spot. The typical site is a shallow, possibly drying up, cattle pond (sometimes tiny) or a marshy area. The thick beds of thin reeds (Eleocharis) at the pond edge are a favored habitat. There are only two records before 2005, possibly due to the species' small size and the difficulty of finding it without a deliberate targeted search. 


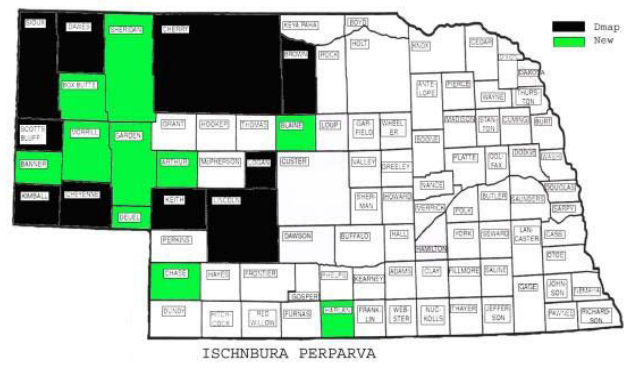

\section{Ischnura perparva (Western Forktail)}

CR: 20, TL: 22-28mm, Spec: 1905, Pub: Keech, 1934

FP: late May to early September

Common. The range of this western species ends in central Nebraska. I. perparva is essentially identical to $I$. verticalis and the area of overlap with I. verticalis covers the whole range in Nebraska and eastern Wyoming. Normally if one species is present at a site the other is also there, even if there are only a few individuals. There are no records of hybridization. Perhaps because of the difficulty of separating it from I. verticalis, there is only one Nebraska county record east of the core range (Harlan County). As with other Ischnura, any pond or marshy area is potential habitat.

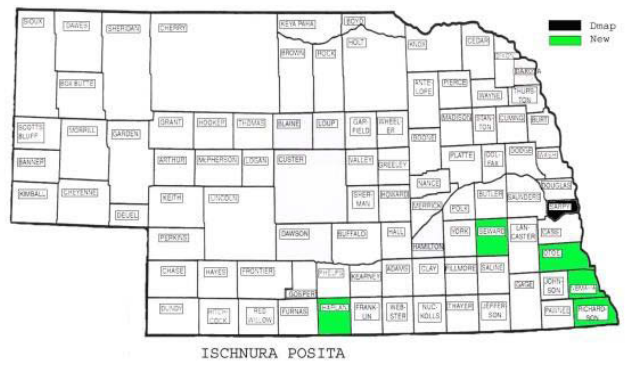

\section{Ischnura posita (Fragile Forktail)}

CR: 6, TL: 21-28mm, Spec: 2005 (IORI), Pub:

Donnelly, 2004c

FP: late June to mid-July

Rare. The five records in southeast Nebraska are on the extreme western border of this eastern species' range with the Harlan County record in central Nebraska an outlier. Our 5 county records of this tiny distinctive species represent 6 specimens, not populations. It has been captured twice at Harlan County Reservoir, but extensive searching after finding each of these individuals did not turn up additional specimens. The Padelfords have had better luck finding it in Fontenelle Forest, Sarpy County, but their sightings, although representing several individuals and repeated sightings in the same area, are not numerous. Their photo from 2004 is the first record of the species in the state. The few records are from heavily vegetated pond edges or marshy areas.

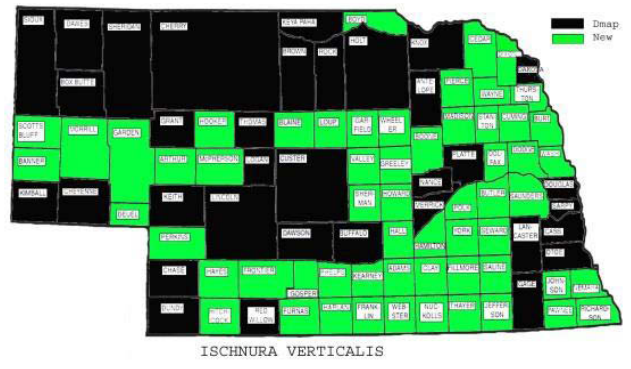

\section{Ischnura verticalis (Eastern Forktail)}

CR: 93, TL: 20-33mm, Spec: 1899, Pub: Keech, 1934

FP: early May to mid-September (some UNSM specimens dated early March 1960).

Very common. The range of this eastern species extends west into Colorado and Wyoming. This and E. civile are the most common and widespread damselflies in the state with 1 . verticalis being found in almost any wet grassy or marshy area. It is not, however, at every such site and it is definitely less common and sometimes harder to find in the western counties. Anywhere you find Ischnura you should find 
I. verticalis. The western I. perparva is almost identical and coexists with I. verticalis in the western half of the state.

Nehalennia - Sprite: This species can be overlooked in areas with Ischnura verticalis but it is slightly smaller and has blue on the sides of the thorax. Both are found in the same habitat, but I. verticalis is always many times more abundant.

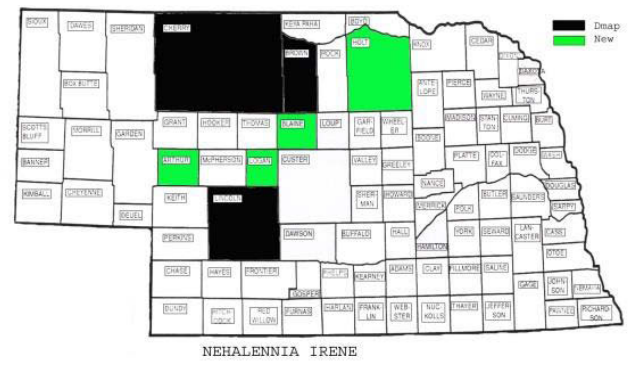

Nehalennia irene (Sedge Sprite)

CR: 7, TL: 24-28mm, Spec: 1952, Pub: Pruess, 1967

FP: late May to early August

Rare. Nebraska is at the southern edge of this transcontinental species' range and there are only scattered records across the Great Plains from central North Dakota, eastern South Dakota and lowa. Nehalennia can easily be overlooked, as it usually flies below the level of the marshy vegetation, but existing records are probably a true indication of its spotty distribution and abundance.

\section{ANISOPTERA (DRAGONFLIES)}

These are with few exceptions larger than damselflies, with thicker abdomens and wings always held out flat when perched. Zygoptera are generally small (dainty) with wings folded over the back and with slender abdomens. There are five families of dragonflies and 62 species found in Nebraska. As with the pond damsels, field experience and time will make separation of families routine.

\section{Aeshnidae - Darners}

The five genera contain 10 large to very large species but only three genera are common and Aeshna and Rhionaeschna contain seven of these 10 species. The common species are colorful blues and greens and they are sometimes very abundant in large feeding swarms.

\section{Aeshna - Darners}

The five Aeshna species are large, uncommon, with two large thoracic stripes and a mosaic pattern of blues and greens on the abdomen. They are frequently found away from water, are mostly present from mid-July into October, and may appear in unpredictable annual invasions of a few days to weeks. 


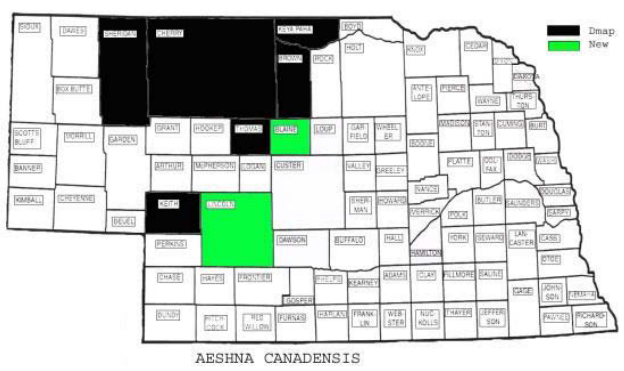

\title{
Aeshna canadensis (Canada Darner)
}

CR: 8, TL: 68-74mm, Spec: 1915, Pub: Kormondy, 1960

FP: mid-July to mid-August

Rare. This is a transcontinental species, but the small isolated population (northwestern and north-central counties of Nebraska plus the Black Hills of South Dakota) is over 300 miles west of the nearest lowa population and 900 miles southeast of the Montana population. They seem to be rare in all counties except Cherry, where they are fairly common. We have only encountered it twice. The first was at the 1998 DSA meeting in Valentine, one of many darners (mostly Rhionaeschna multicolor) hanging over a small stream. The second time was one of several flying over the muddy edge of the North Loup River at Brewster on July 18, 2005.

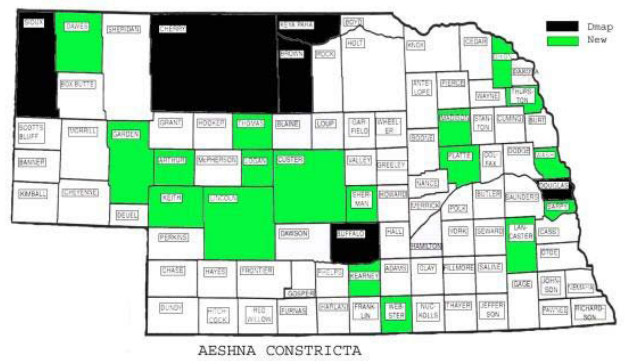

\author{
Aeshna constricta (Lance-tipped Darner) \\ CR: 24, TL: 68-72mm, Spec: 1951 (IORI), Pub: \\ Needham, et al, 1955 \\ FP: early July to mid-October
}

Fairly common. Southern Nebraska is almost the southern boundary for this northern transcontinental species. This is the commonest and most widespread of the Nebraska Aeshna. It is hard to make abundance comparisons with the limited records available but during the 1951 collecting in Lincoln County there were $30 \mathrm{~A}$. constricta, 10 A. interrupta, and 4 A. umbrosa caught. At the July 1998 DSA meeting there were 29 A. constricta, 19 A. canadensis, $3 A$. interrupta and $3 A$. umbrosa reported. We do not have all the records from the meeting, but we think this is a representative sample. The species is difficult to identify on the wing but probably resident in many counties. This darner stays late and is probably the only one you would find in late September and certainly in October - one was caught at Liberty Cove RA, Webster County, on October 17, 2012. There are no pre-1951 specimens in the UNSM collection; the specimen Keech (1934) lists from Douglas County is an A. interrupta specimen.

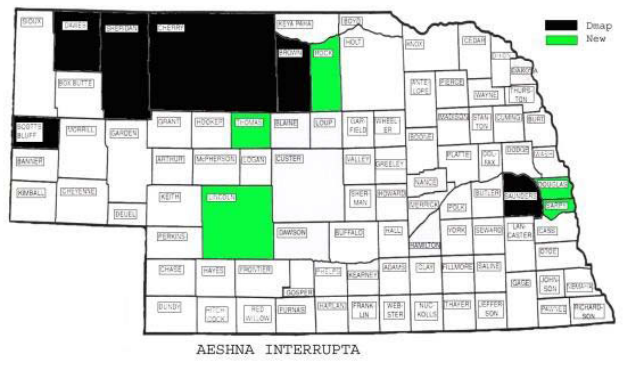

\section{Aeshna interrupta (Variable Darner)}

CR: 11, TL: 72-77mm, Spec: 1911, Pub: Keech, 1934

FP: mid-July to mid-September

Rare. Central Nebraska is close to the southern edge of the range but it has only been found in a cluster of 
eight counties in the western half of the state and a cluster of 3 counties in the east (Saunders, Douglas \& Sarpy). It is evidently an irregular, late season, irruptive species from farther north (northwest records) or east (eastern records). There are 10 specimens from Lincoln County on Aug. 27 \& 28, 1951, 12 from Thomas County in late July 1969 and 6 from the 1998 DSA meeting in Cherry County. There are only two records since, one at Heron Haven, Douglas County, Aug. 19, 2012, and one at Fontenelle Forest, Sept. 27, 1999.

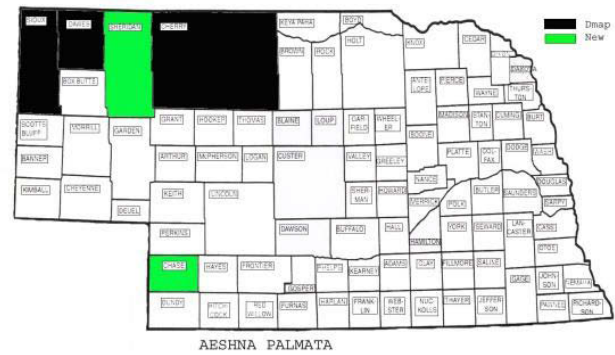

\section{Aeshna palmata (Paddle-tailed Darner)}

CR: 5, TL: 65-75mm, Spec: 1912, Pub: Pruess, 1967

FP: mid-July to mid-September

Uncommon. There are numerous records of this western species in five western counties. Abundance is impossible to estimate, as Aeshna are usually difficult to catch and difficult to separate in flight from the always abundant Rhionaeschna multicolor. Between 6 and 7 PM on July 20, 2006, I caught a male and female out of a scattered group of widely spaced Aeshna hawking over the Fort Robinson SRA campground. This is a typical encounter. The species was not listed by Keech (1934), but at least 5 of the $A$. umbrosa he lists are $A$. palmata.

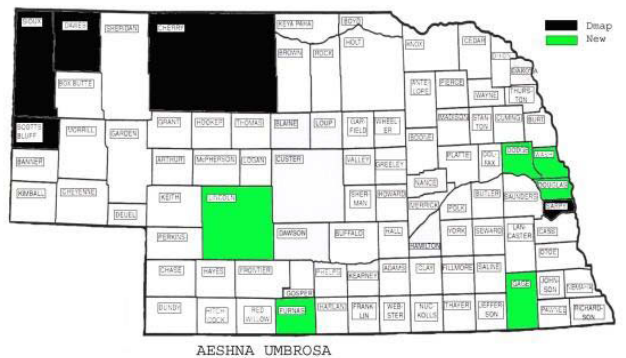

\section{Aeshna umbrosa (Shadow Darner)}

CR: 11, TL: 68-78mm, Spec: 1912, Pub: Keech, 1934

FP: mid-July to early October

Uncommon. This transcontinental species recorded commonly in lowa and Kansas has limited records in Nebraska, North and South Dakota, Wyoming and Montana. The few records from Nebraska are concentrated, as for $A$. interrupta, on the eastern edge and in the northwestern portion of state - those counties close to lowa and the Black Hills. Records from Heron Haven, Douglas Co., would suggest $A$. interrupta and $A$. umbrosa are short-term visitors - a few days to a week.

\section{Anax - Green Darner}

The single Nebraska species in this genus is a large darner similar to Aeshna but with a bright green thorax and blue abdomen. It is primarily associated with ponds and lakes.

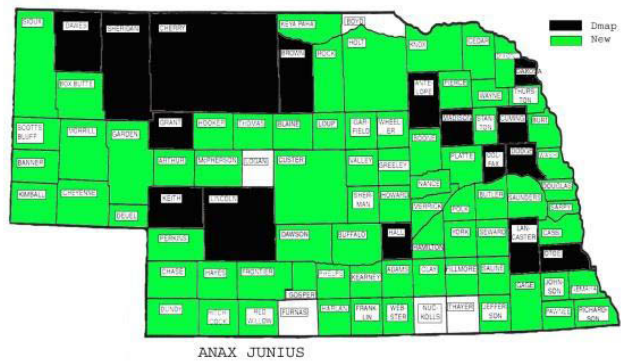

\section{Anax junius (Common Green Darner)}

CR: 88, TL: 68-80mm, Spec: 1912, Pub: Keech, 1934

FP: mid-April to late September 
Common. This transcontinental species is one of the earliest species to appear, as a migrant from farther south, and the most widespread darner. It is expected in every county but is rarely common at any given site. It is a pond species, preferring small fish-free ponds for egg laying but likely to be seen circling low over the surface and a few feet out from shore at almost any pond or lake.

Boyeria - Spotted Darner - A medium-sized, rare, brown darner with a pair of pale spots on each side of the thorax.

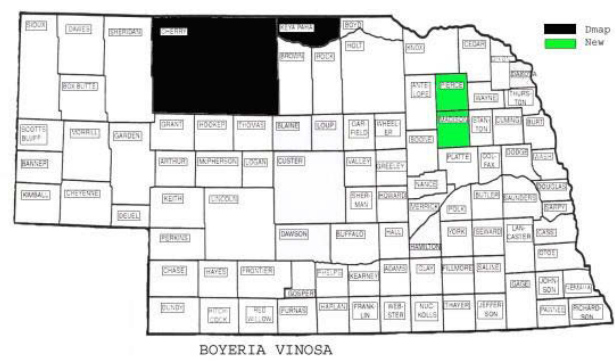

\section{Boyeria vinosa (Fawn Darner)}

CR: 4, TL: 60-71mm, Spec: 1984, Pub: Beckemeyer \& Hummel, 1997

FP: mid-July to mid-August

Rare. The few Nebraska records of this eastern species are western outliers from the core range - western lowa east to the Atlantic, north to Canada and south to Texas. It was first reported from the city park in Valentine, Cherry County, on a tributary to Minnechaduza Creek, on Aug. 16, 1997, by Roy Beckemeyer (UNSM \# 3932) and subsequently recollected in the same area in July 1998 and July 2013. It was also found Aug. 1997 and July 1998 in Keya Paha County on streams running into the Niobrara River near the Norden Bridge. The Dot Map record from Brown County is actually a Keya Paha record. There are no records from South Dakota. A recent examination of unidentified nymphs at the University of Nebraska by Ken Tennessen turned up specimens from Pierce County - North Fork of the Elkhorn River, 3 miles SSE of Pierce, Oct. 30, 1984, and Madison County - Buffalo Creek, 1 mile SW of Meadow Grove, Aug. 10, 1984. It is possible the habitat has changed in the 30 years since these records were collected and the species may no longer be present in these counties. The species flies low over streams, often exploring around log tangles in the stream.

\section{Nasiaeschna - Cyrano Darner}

There is only one large species in the genus. The angled frons is distinctive when viewed in the hand, and its slow fluttering foraging flight is a useful characteristic for field identification. This species is very similar to and easily confused with Aeshna as it patrols over streams or ponds.

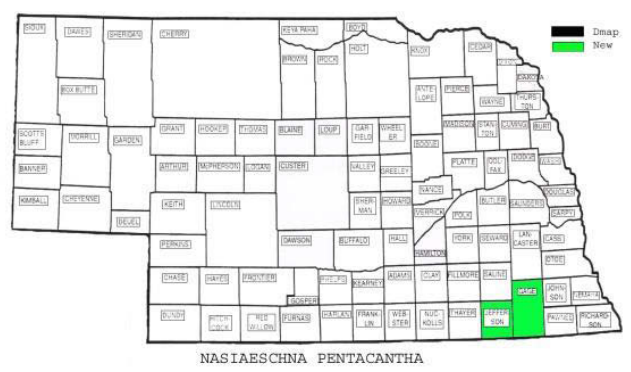

\section{Nasiaeschna pentacantha (Cyrano Darner)}

CR: 2, TL: 70-73mm, Spec: 2005, Pub: Sibley 2006a

FP: July

Rare. This eastern species is found west to central Kansas and central lowa but barely reaches 
southeastern Nebraska. The first state records were collected in Gage County, Rockford Lake, 9 miles southeast of Beatrice, July 5, 2005, when several individuals were seen, and in Jefferson County, Rock Creek Station SHP, July 7, 2005. The two records are from slow, sluggish, heavilyshaded streams. Sight records from the heavily-shaded end of a borrow pit, July 1, 2006, near West Point, Cuming County, another along a small sandy stream in farm land July 3, 2012, Pawnee County (Turkey Creek) would indicate this is regular in the southeastern part of state.

\section{Rhionaeschna - Blue-eyed Darners}

A typical darner, formerly in the genus Aeshna. There is one rare Nebraska species and one super-abundant and widespread species in this genus. The bright blue eyes immediately separate these from other darners.

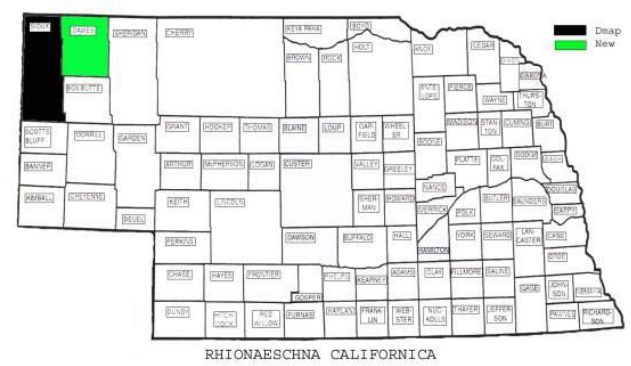

\section{Rhionaeschna californica (California Darner)}

CR: 2, TL: 57-61mm, Spec: 1979 (Chadron State College), Pub: Bedell, 2001

FP: late May to mid-June

Rare. The Black Hills of South Dakota and the northwest corner of Nebraska are the eastern range limit of this western species. The first Nebraska record was a male collected in Dawes County June 5, 1979, south of Chadron, by Randy Lawton. Two were collected in Hat Creek Badlands, Sioux County, on May 25, 2000, by Steve Spomer (UNSM specimens). One was collected in Sowbelly Canyon, Sioux County, June 4, 1999, by Paul Bedell (Bedell, 2001), and in 2013 several were found, in early June, at a pond in the Monroe Canyon area of Sioux County (Gilbert-Baker SWMA) by Matt Brust and Steve Spomer. We found them common at the same pond on June 5, 2014, but only R. multicolor on June 22, 2013. In the Black Hills we found R. californica at Cold Brook Lake on June 3, 2013, and by June $6,2013, R$. multicolor was also present. It is evidently a regular resident species in the northwest corner of Nebraska. The rarity of reports is due to a combination of the difficulty of collecting it, the difficulty of separating it in flight from the abundant $R$. multicolor and the short flight period. Both Rhionaeschna are early season species with bright blue eyes and occupy the same habitat. $R$. californica is slightly smaller, usually flies closer to the water than $R$. multicolor and is more likely to be flying in the cattails rather than over open water.

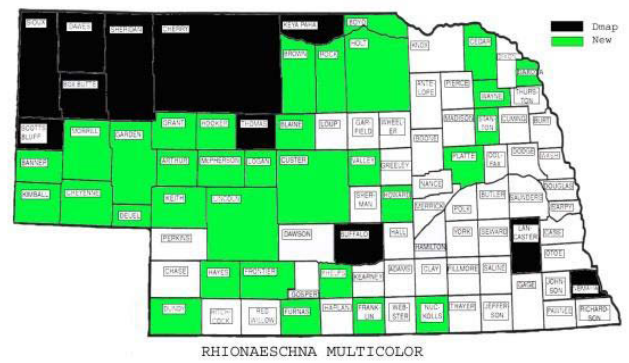

\section{Rhionaeschna multicolor (Blue-eyed Darner)}

CR: 44, TL: 68-72mm, Spec: 1913, Pub: Keech, 1934

FP: late May to late August

Common. Eastern Nebraska is close to the eastern edge of range but there are numerous records north 
and south of the state. It is widespread, although there are fewer records from the east and particularly the southeast. It is the most abundant darner in the state and is often present in incredible numbers. It is frequently seen in large feeding swarms, and during the heat of the day it can be found hanging from branches of pines or cedars in shelter belts or other plantings. There was one report from the 1998 DSA meeting of catching 16 roosting individuals in one net swing.

\section{Gomphidae - Clubtails}

Not all clubtails have clubtails and the 14 species of 8 genera are medium to very large in size, uncommon, rarely seen in numbers and frequently seen only in flight. When perched they may be resting flat on the ground, on rocks near the water or hanging vertically on grass stems or branches well away from the water. The general pattern is one of yellow and black on the abdomen and stripes on the thorax with the terminal abdominal segments often more brightly colored than the rest of the abdomen.

\section{Arigomphus - Pond Clubtails}

This genus includes two uncommon pond species, a northern and southern species with some overlap. They are rather plain and without a clubtail.

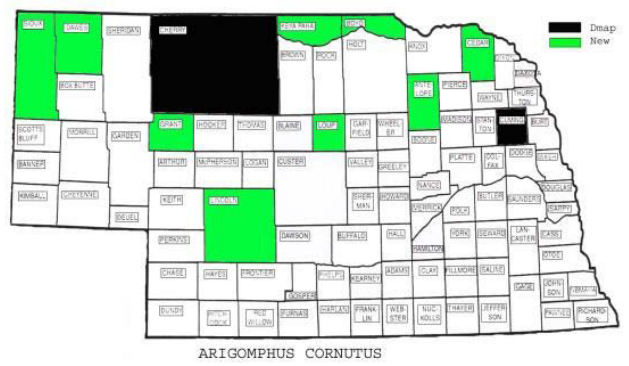

\section{Arigomphus cornutus (Horned Clubtail)}

CR: 11, TL: 55-57mm, Spec: 1887, Pub: Keech, 1934

FP: early June to early July

Uncommon. Most of the records of this mid-western species are in lowa and Minnesota with northern lowa representing the southern limit. The records in the northern counties of Nebraska and southern counties of South Dakota connect the eastern population to a narrow band of scattered western records extending from eastern Colorado through the Black Hills of South Dakota to Canada. The Lincoln County record is the southernmost for the species. At Hull Lake SWMA, Boyd County, we found numerous individuals July 3, 2008, sitting on floating algae in the small permanent pond. In most other encounters there were single individuals on lily pads or the bare shore of permanent ponds.

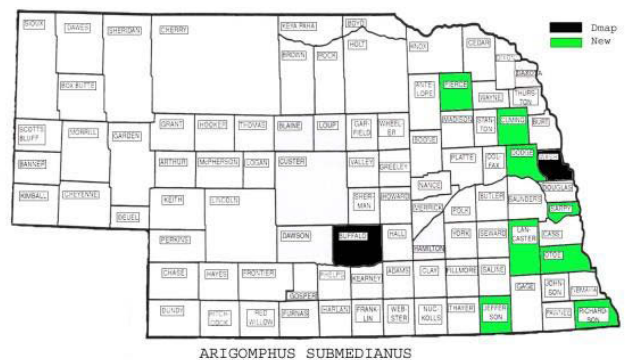

Arigomphus submedianus (Jade Clubtail)

CR: 10, TL: 51-55mm, Spec: 1997, Pub: Beckemeyer, $1998 b$

FP: mid-June to mid-July 
Uncommon. Eastern Nebraska is on the western edge of the range for this mid-western pond species. It can be found east to Indiana and south to the Gulf of Mexico. Northern Nebraska and lowa are the northern limit for the species and Buffalo County is the western-most record. The range barely overlaps that of $A$. cornutus in the northeastern part of the state, $A$. cornutus south of its core range in Cuming County and $A$. submedianus north of its core range in Pierce County. It is often found perching on the bare shore of ponds or on sandbars in small streams, but never more than a few.

\section{Dromogomphus - Spinylegs}

This rare, large, eastern pond species is separable from all other gomphids by the prominent femoral spines on the long hind legs, but it has been collected only twice in the state.

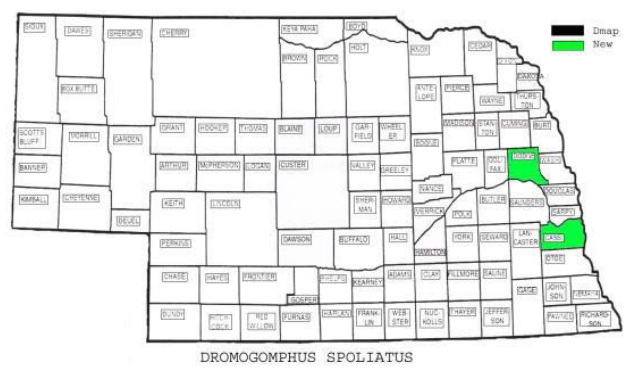

Dromogomphus spoliatus (Flag-tailed Spinyleg)

CR: 2, TL: 56-65mm, Spec: 2006 (Ken Tennessen), Pub: Sibley, 2011a; Peterson, 2014

FP: late July to early August

Rare. This is a Midwestern species found from western Ohio to eastern Kansas and south to the Gulf of Mexico with northern lowa being the northern limit of the range. One exuvia (identified by Ken Tennessen and in his collection) was found in Cass County at a small fishing lake near the campground in Mahoney SP, on July 26, 2006. On August 3, 2014, Brian Peterson caught a female in Dodge County at the Fremont Lakes SRA (Peterson, 2014). Both records are at the western edge of the range. There may be a resident population of this late season species in eastern Nebraska as we have spent limited time checking Nebraska in late July and August.

\section{Erpetogomphus - Ringtails}

Only one member of the genus reaches a few southern counties, and that is a small, brightly colored stream species with conspicuous abdominal rings on each segment and easily separated from any other gomphid in the state

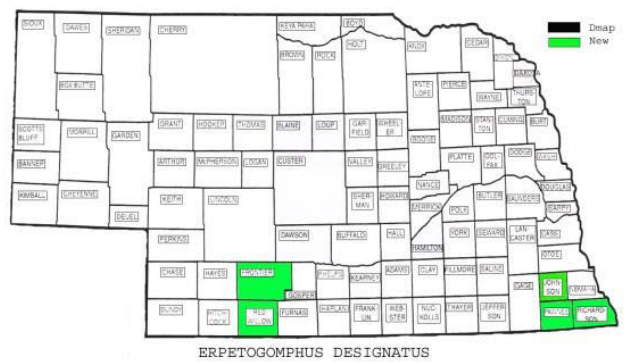

Erpetogomphus designatus (Eastern Ringtail)

CR: 5, TL: 49-55mm, Spec: 2006, Pub: Sibley 2011a

FP: early July to late September

Rare. This eastern and southern species ranges from 
the East Coast west into eastern Colorado and Texas with a disjunct population in the Black Hills of South Dakota. Southern Nebraska is on the northern edge of the contiguous range and all five county records are close to the Kansas border. It was first collected July 4, 2006, in Richardson County at Kinter's Ford SWMA by Matt Brust (UNSM), but the specimen was not identified until 2012. Don and Janis Paseka found the first reported specimen, a male, in Red Willow County at Bartley Diversion Dam near Indianola on Sept. 24, 2010, (Sibley 2011a). On July 3, 2015, there were several on Turkey Creek, Pawnee County, with at least 10 Progomphus obscurus, and on July 5, 2012, we found a number in Four Mile Creek SWMA, Richardson Co. (near jct. Rt. 8 \& 105). On July 21, 2014, we found one in Frontier County at the outflow from Red Willow Dam (Sibley 2014b). The latter three records were on small, clear, gravel/sand streams through farm land or riparian corridors. On July 18, 2015, Dave Rogers photographed one at Twin Oaks WMA, Johnson County.

\section{Gomphurus - Common Clubtails}

There are two medium-sized stream species, G. vastus, found only along the Missouri and lower Platte Rivers, and G. externus, widespread across the state. Progomphus, Stylurus and Ophiogomphus are the only gomphids sharing their habitat.

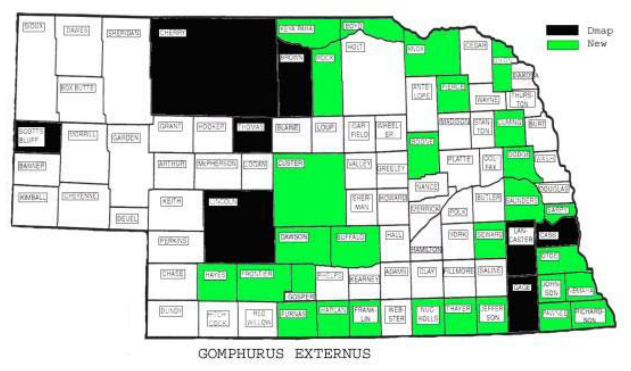

\section{Gomphurus externus (Plains Clubtail)}

CR: 37, TL: 52-59mm, Spec: 1888, Pub: Muttkowski, 1910

FP: late May to late July

Uncommon. There are scattered records west (to Utah) and north (to Canada) of Nebraska, but the state is essentially the western and northern edge of this Midwestern species' range. In Nebraska there are numerous records to the Panhandle but only one Panhandle record. G. externus is usually found as a single individual near or on the edge of a flowing stream or small river. On June 22, 2009, we found this species and Progomphus common at the edge of a stream in Johnson County. The two species alternated along a considerable length of a shallow sandy stream at the bottom of a 15-footdeep ravine. Similarly in Boyd County on July 3, 2008, the same two species were common and intermixed on a long sandbar in a shallow permanent creek.

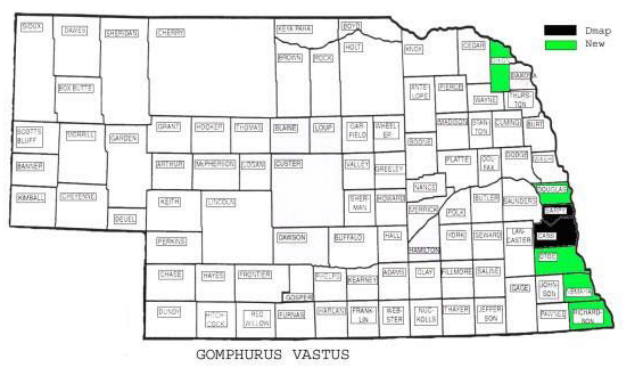

\section{Gomphurus vastus (Cobra Clubtail)}

CR: 7, TL: 47-57mm, Spec: 1992, Pub: Johnsgard, 2001

FP: early June to early July

Uncommon. This eastern and big river species is found from the Gulf of Mexico to Canada and west to 
the Missouri River. All our records are from counties bordering the Missouri River and it probably occurs in all such counties, or at least until the Missouri turns west. It is reliably found in late June/early July in Nemaha and Richardson Counties but seems less common at other sites along the river. In 2012, a year after the Missouri was out of its banks for over 100 days, there were none at the standard sites. It has been found in weedy vegetation of the river bank or in mowed paths just back from the river and is sometimes common. On July 4, 2005, 10-12 were flushed from the banks of the river at Brownville SRA, Nemaha County.

\section{Ophiogomphus - Snaketails}

The one Nebraska member of this genus is a large, widespread river/stream species with a pale green thorax.

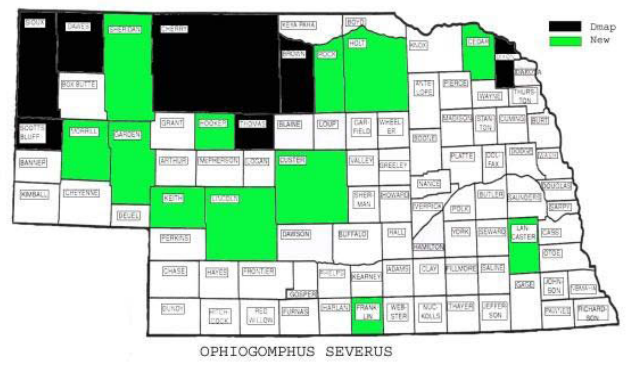

Ophiogomphus severus (Pale Snaketail)

CR: 19, TL: 49-52mm, Spec: 1905, Pub: Keech, 1934

FP: mid-June to late August

Fairly common. This western species is found most frequently in the western half of the state with scattered records to the Missouri River and almost no records in the southern counties. There is one record in lowa, one in South Dakota and two in Kansas, so Nebraska represents the eastern extension of the range. It is a stream and river species often found on sticks and logs in a stream or in fields near the river. On July 2, 2010, we found numerous individuals in dense stands of yellow clover well back from the Niobrara River at Marsland, Dawes County. The river is about 5 feet wide at this point and no individuals were found on the river.

\section{Phanogomphus - Common Clubtails}

These two Nebraska pond species are similar to Gomphurus: P. graslinellus is restricted to southeastern and northwestern counties and $P$. militaris is widespread but a southern species. Arigomphus are the only other gomphids likely to be with them.

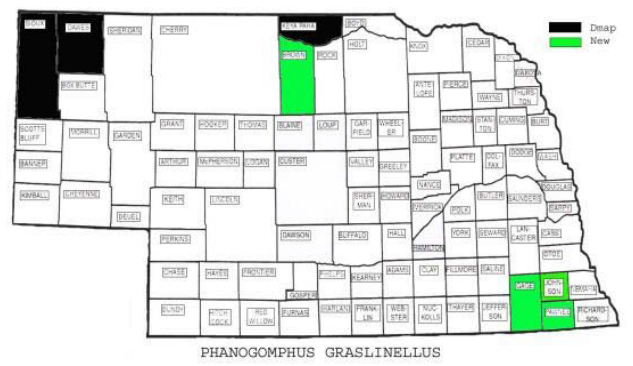

\section{Phanogomphus graslinellus (Pronghorn Clubtail)}

CR: 7, TL: 47-53mm, Spec: (est. 1910), Pub:

Beckemeyer, 1998b

FP: late May to early July

Rare. The Nebraska records of this species have very different affinities. The records from Gage, Johnson and Pawnee counties in the southeast corner are outliers from a population extending from Arkansas through eastern Kansas and 
lowa north to Canada and east to Ohio. The records from Sioux and Dawes counties are part of the range starting in eastern Colorado and extending through the Black Hills of South Dakota to Canada where it connects to the eastern range. Records from Keya Paha and Brown counties are in limbo between these two ranges and perhaps just vagrants. The first record (probably 1910-1915) was from War Bonnet Canyon in Sioux County and was identified as Gomphus lividus by Keech (1934) and re-identified (Donnelly, 2000a) as G. graslinellus. This specimen is in the pinned reference collection at UNSM, a female with terminal segments missing. Beckemeyer (1998b) lists a Mike May record in Keya Paha County from July 1998 as the first state record. It has since been collected at Cub Creek Lake in Keya Paha County July 6, 2008; at a tiny stream on the Pawnee/Richardson County line June 21, 2009; at a small fishing lake in Keller Park SRA, Brown County, on May 30, 2013; and on Rockford Lake SRA, Gage County, on June 10, 2013. All 4 records are of males and the last three are teneral individuals.

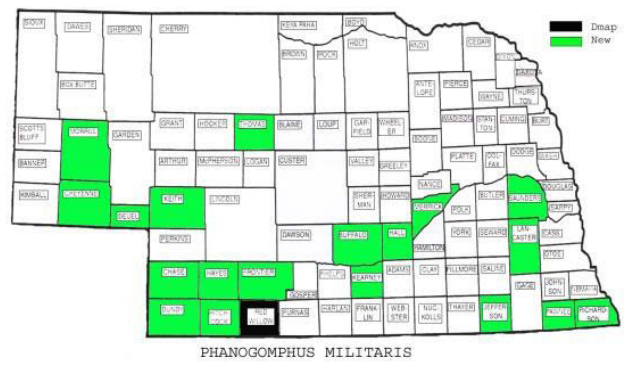

Phanogomphus militaris (Sulphur-tipped Clubtail)

CR: 20, TL: 47-53mm, Spec: 1985, Pub: Beckemeyer, $1998 b$

FP: early June to late July

Fairly common. Nebraska is at the northern limit of this mid-western species' range, a range extending from southern Texas through Oklahoma and Kansas to southern Nebraska. This is a pond species which is sometimes very common. At Rock Creek Lake in Dundy County on July 2, 2009, there were over 20 at the edge of the lake. It is mainly restricted to the southern third of the state, with one northern record in Thomas County. It was first recorded by Sid Dunkle on July 15, 1998, on the Republican River near McCook, Red Willow County, but larvae had been collected in 1985 in Saunders County (OC\# 427858). The species has now been recorded in numerous counties from the Missouri to the Panhandle and north into the Sandhills.

\section{Progomphus - Sanddragon}

This widespread and frequently common river/stream species can be separated from other clubtails by the small dark patch at the base of each wing.

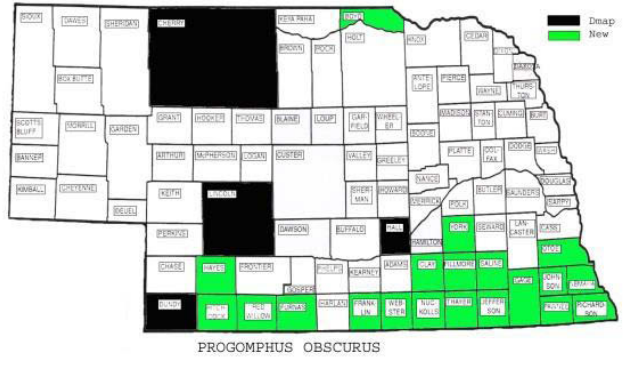

records except those in Cherry and Keya Paha Counties are in the southern third of the state

\section{Progomphus obscurus (Common Sanddragon)}

CR: 24, TL: 47-53mm, Spec: 1960, Pub: Pruess, 1967

FP: early June to late July

Common. Western Nebraska represents the northwest edge of this eastern species' range. All 
where it is often common on sand bars in wide, shallow, slow-moving streams or rivers. See notes under Gomphurus externus for encounters in Johnson and Keya Paha Counties. In Pawnee County, July 3, 2012, we found over a dozen on a short stretch of sandbars in a tiny sandy stream through farm land. It is sometimes found in the vegetation on the sandbars, but usually just on open sand or mud.

\section{Stylurus - Hanging Clubtails}

An uncommon but widespread genus found on small streams to large rivers. Most records are of emerging individuals, since adults are difficult to find and catch as they speed low over the water. When perching they hang vertically from grass or brush.

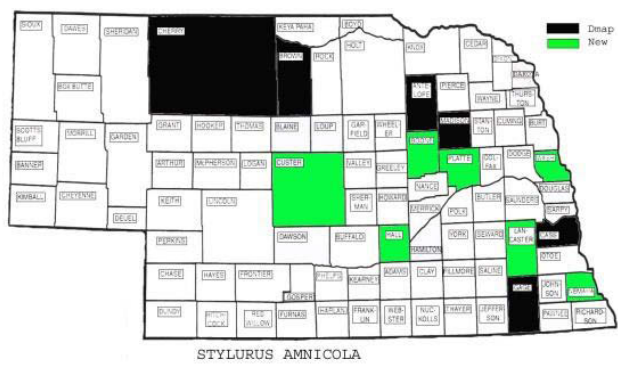

\section{Stylurus amnicola (Riverine Clubtail)}

CR: 13, TL: 47-49mm, Spec: 1909, Pub: Keech, 1934

FP: mid-June to late July

Rare. This Midwestern species is found east to the Atlantic and west across two-thirds of Nebraska. It is hard to judge their abundance statewide. The 20 specimens I know of ( 5 were from Cherry County at the 1998 DSA meeting) come from 13 counties. We have collected single individuals (two teneral) on only 5 occasions and usually in weeds and brush along or back from rivers.

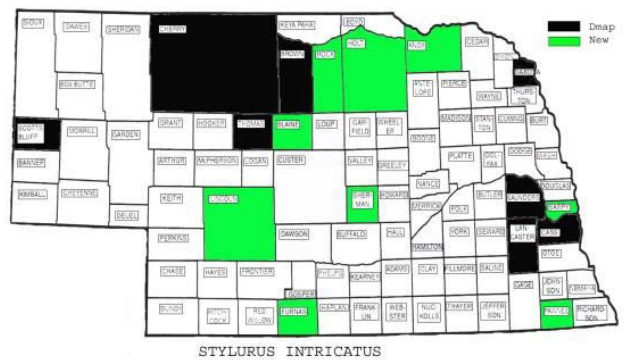

\section{Stylurus intricatus (Brimstone Clubtail)}

CR: 17, TL: 41-55mm, Spec: 1912, Pub: Keech, 1934

FP: mid-June to mid-August (3 early October, 1914 records)

Uncommon. Nebraska is on the northern limit of this western species' range that continues into western lowa. The records are scattered all across the state. This is a species, like the preceding, for which it is hard to judge the abundance statewide. We have collected it only 4 times, but at the 1998 DSA meeting 25 specimens were obtained in Cherry County and 2 in Brown County. Of the 23 specimens in the University of Nebraska, 21 were collected between 1912 and 1914. Cherry County is unquestionably a super habitat for many species, but were statewide conditions so much better elsewhere in 19121914? The next comparable collecting would be in the 1950s and 1960s in Lincoln County and no Stylurus are found in those extensive collections. On July 5, 2011, we found a considerable number emerging on the Loup River at Dunning, Blaine County, but other records were single tenerals. 


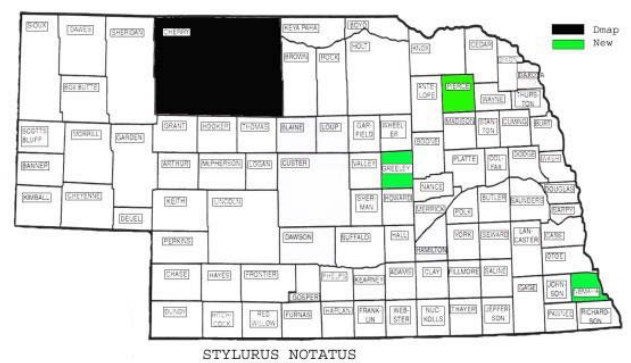

STYLURUS NOTATUS

\section{Stylurus notatus (Elusive Clubtail)}

CR: 4, TL: 52-64mm, Spec: 1998 (IORI), Pub:

Beckemeyer, 1998b

FP: early July to mid-August

Rare: Nebraska is west of the main range of this mainly Midwestern species. Hal White collected the first state record July 19, 1998, in Cherry County during the DSA meeting. This was a male in a small sandy stream (Minnechaduza Creek) and Sid Dunkle collected another the next day and reported seeing at least two others. (In the same collecting session Sid caught numerous $S$. amnicola and S. intricatus.) We collected one teneral male July 1, 2005, in the grass on a sloping river bank along the Missouri River at Brownville SRA, Nemaha County. An adult male was collected Aug. 19, 2009, in the small sandy stream just below a power company reservoir at Spalding, Greeley County, and a teneral was collected July 7, 2016, on the North Fork of the Elkhorn River near Hadar, Pierce County.

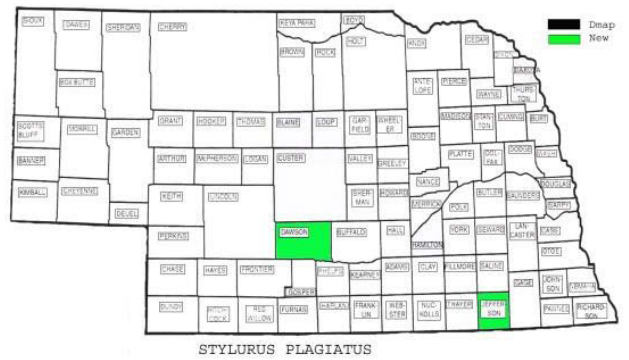

Stylurus plagiatus (Russet-tipped Clubtail)

CR: 2, TL: 57-66mm, Spec: 2005 (IORI), Pub: Sibley, 2006a

Rare. Nebraska is at the northern edge of a range extending from the Atlantic and Gulf Coast north to New York and Minnesota and west to lowa and central Kansas. The two Nebraska records are on the western and northern edge of the range a teneral male collected July 7, 2005, at Rose Creek (near Reynolds), Jefferson County, and a male photographed south of Gothenburg, Dawson County, on Sept. 1, 2014, by Dave Rogers. The first was in thick roadside vegetation back from the small stream and the second was one of several in thick weeds back from a canal.

\section{Macromiidae - River Cruisers}

The species probable in Nebraska are large blackish dragonflies with bright green eyes and one or more yellow spots on the abdomen. They will more frequently be seen in flight over a river or stream than perched. 
Macromiidae - River Cruisers One genus and one species

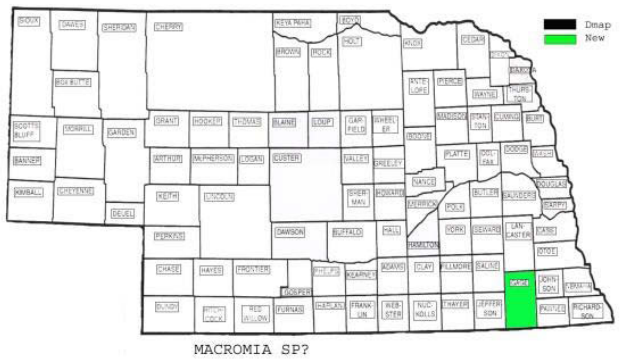

Macromia - River Cruisers

Macromia illinoiensis or pacifica (Swift or Gilded River Cruiser)

CR 1, T.L. 65-76mm, Spec: 1985, Pub: this paper

The one record is an F-1 nymph in the University of Nebraska collection collected Aug. 16, 1985, on Arkeketa Creek in the southeast corner of Gage County and identified by Ken Tennessen (this nymph could only be identified to genus). This locality is some 60-90 miles west of the closest record in Missouri for M. illinoiensis and about the same distance north of records in Kansas for both M. illinoiensis and M. pacifica.

\section{Corduliidae - Emeralds}

There are six species in three very distinct genera. Three of the four Epitheca (Baskettails) are common while the fourth species and other two genera are rare. They are medium to large in size and drably colored. The common name of emeralds refers to the bright green eyes of some species.

\section{Epitheca - Baskettails}

This is a group of four small brownish pond species with no metallic color and dull green eyes. They are found around ponds or lakes, patrolling slowly or hovering just offshore and are frequently very common. E.princeps is much larger than the other Epitheca with large black wing spots.

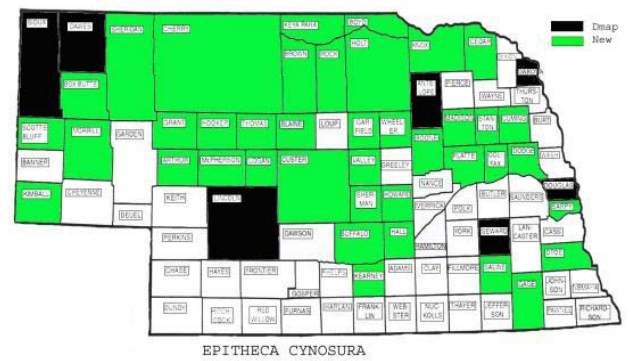

Common. An early season eastern species whose range extends west to western South Dakota, Nebraska, Kansas and eastern Wyoming. It is found all across the state and is probably to be expected in all counties, although strangely unrecorded from almost all southern counties. A pond and lake species, it usually flies short patrol routes around the edges of ponds at a height of 2-8 feet. When perched, it hangs vertically from a branch. On June 8, 10 and 11, 2014, Barlow Rhodes and Fred Sibley found the species present at every stop in Buffalo, Howard, Hall, Seward, Saline, Cuming and Dakota Counties. At Ravena Park in Buffalo County the species was abundant and individuals were 
spaced every 30-50 yards around the lake. On July 6, 2008, at Cub Creek Lake in Keya Paha County, the territorial males were so abundant and closely packed that we caught 5 in 5 minutes without moving from one spot in a small cove. In the southwestern Panhandle the range overlaps with E. petechialis. On July 3, 2010, we collected 10 Epitheca around the borrow pit ponds in the campground near the Scottsbluff zoo. Four of these were E. cynosura, five were E. petechialis and one was intermediate (Nick Donnelly). Other intermediates have been collected in Box Butte, McPherson, Morrill and Hooker Counties. At Guernsey, WY, 60 miles upstream on the Platte from Scottsbluff, we found only E. cynosura.

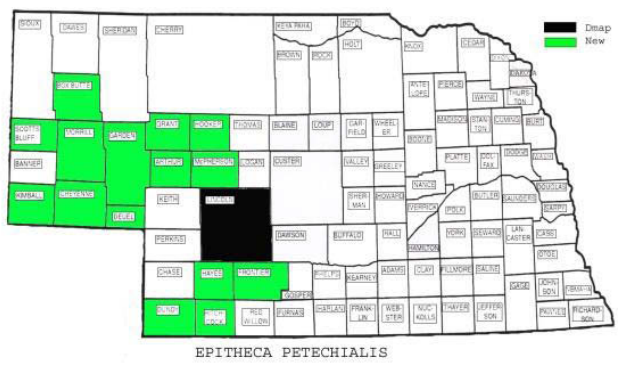

\section{Epitheca petechialis (Dot-winged Baskettail)}

CR: 16, TL: 41-43mm, Spec: 1998 (IORI), Pub: Sibley, $2014 a$

FP: late June to mid-July

Fairly common. This mid-western species extends from Texas into southwestern Nebraska with records in the Black Hills of South Dakota. All records are in the western one-third of the state but not in the northern row of counties. Habitat and behavior are like cynosura. Sid Dunkle collected the first record in Lincoln County July 15, 1998, after the DSA meeting, and labeled it E. petechialis/E. costalis, which Beckemeyer (1998b) listed as E. costalis, but Donnelly identified as E. petechialis. At Scottsbluff we found some individuals with the typical dark spots on the nodus and antinodal cross veins but most individuals have lacked these marks and are impossible to distinguish from $E$. cynosura on the wing. See E. cynosura for discussion of intermediates.

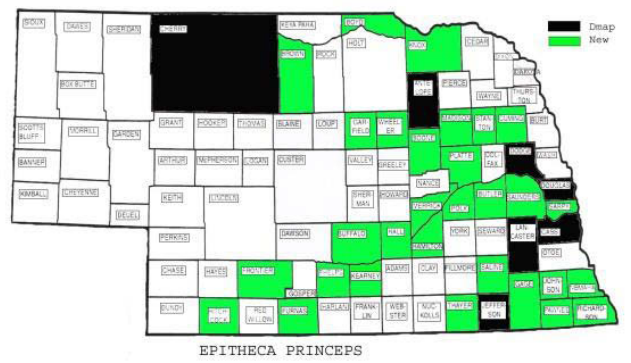

\section{Epitheca princeps (Prince Baskettail)}

CR: 37, TL: 58-78mm, Spec: est. 1913, Pub: Keech, 1934

FP: late June to late August

Common. The range of this eastern pond species extends west to central Nebraska, central Kansas and western Oklahoma. It is widespread in the eastern half of Nebraska and is to be expected in all counties in that area. It often patrols over lawns and fields away from water, where it is more easily netted, but at ponds it usually patrols the edge beyond net range. It is often the first species found at a pond in the morning and is frequently still there after the sun has set.

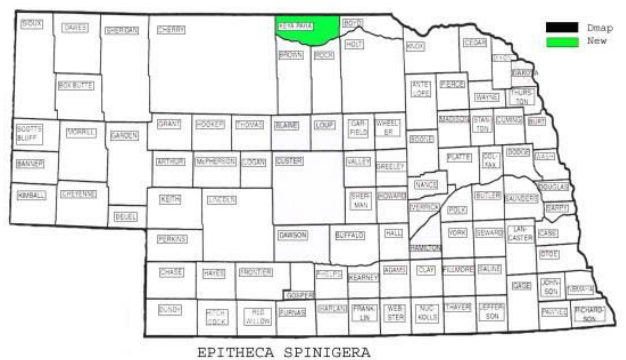

\section{Epitheca spinigera (Spiny Baskettail)}

CR: 1, TL: 43-47mm, Spec: 2008 (IORI), Pub: Sibley $2011 a$ 
Accidental. This northern trans-continental species has been recorded south to southern Wisconsin. There is only one record for Nebraska - a male collected July 6, 2008, at Cub Creek Lake west of Springview, Keya Paha County (about 250 miles WSW of the main range). This individual was with a large group of $E$. cynosura foraging over the lawn near a small lake. It is difficult to separate on the wing from E. cynosura.

\section{Neurocordulia - Shadowdragons}

These are moderate sized, brownish, river and stream species. They are only active for a short period (15-20 minutes) at dusk or later and thus rarely seen or collected, and only one species has been found in Nebraska.

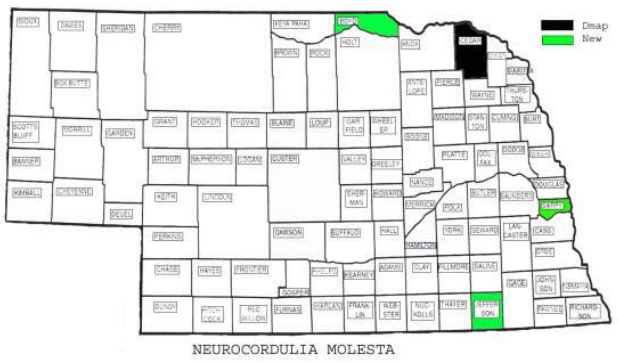

\section{Neurocordulia molesta (Smoky Shadowdragon)}

CR: 4, TL: 45-53mm, Spec: 1984, Pub: Troelstrup, et al., 1985

Rare. Nebraska records may seem like outliers from the records to the south in Kansas and to the east in Wisconsin, but the genus is rarely collected and it may be more common and widespread than the few records would indicate. It is a species usually found only after sunset flying low over rivers. It is difficult to catch, feeding sites are difficult to locate, and people, including the authors, rarely collect after sunset. There are four county records: a teneral and now fragmentary specimen, (UNSM 0000877), was caught at a light trap near Fairbury, Jefferson County, between June 3-8, 1990, (C.A. Springer, pers. com.), and Troelstrup, et al., 1985, collected numerous nymphs (UNSM alcohol collection) from the Missouri River in Boyd and Cedar Counties. More recently, the Padelfords photographed an adult (OC\# 461533) at Fontenelle Forest on June 1, 2016, and Tony Palmer photographed another there in 2017. Nick Donnelly identified the light trap record and Ken Tennessen confirmed the nymph identifications.

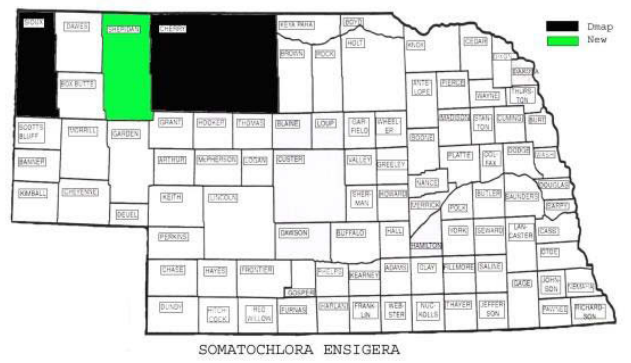

\section{Somatochlora ensigera (Plains Emerald)}

CR: 3, TL: 48-51mm, Spec: 1997, Pub: Beckemeyer, 1998 a

FP: mid-July to mid-August

Rare: This is a Midwestern species with scattered records from Ohio into Wyoming (Beckemeyer, 1998a). It seems to prefer, small, clear, sandy, flowing streams through prairie habitat, and all Nebraska records are from the northwestern counties. Roy Beckemeyer (1998a) and Nick Donnelly collected the first state records on Boardman Creek, Cherry County, on August 19, 1997. Participants at the 1998 DSA meeting in Valentine collected 19 additional records (Beckemeyer \& Hummel, 1998b) on Boardman Creek 
in mid-July and one on Steer Creek near Merritt Reservoir. On July 28, 1998, Steve Hummel (Beckemeyer and Hummel, 1998b) found them still common at Boardman Creek. There is one Dot Map record from Sioux County without data but attributed to HKB99. We collected one in Pine Creek (near Smith Lake), Sheridan County, on July 16, 2011, and did not see others there.

\section{Libellulidae - Pond Dragonflies}

These normally perch on grass, bushes, rocks or similar and, unlike the other four families of anisoptera, in a horizontal positon rather than hanging vertically. The 12 genera and 31 species represent most of the anisoptera species a casual observer would know. They vary greatly in size and pattern, are found primarily on ponds or lakes and the majority of adult males, and many of the females, are easily identified in the field. Only some Sympetrum (Meadowhawks) would present problems for a casual observer.

\section{Brachymesia - Tropical Pennant}

There is only one record for the state.

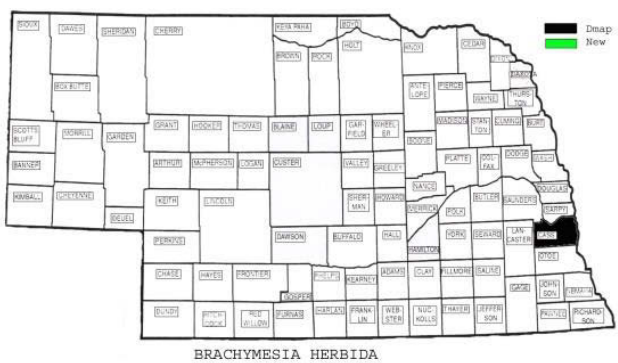

\section{Brachymesia herbida (Tawny Pennant)}

CR: 1, TL: 43-46mm, Spec: 1914, Pub: Donnelly 2000a

Accidental. This Central and South American species barely reaches Texas and Florida. An immature male, in the pinned reference collection of UNSM, was collected August 2, 1914, by E.G. Anderson at Louisville, Cass County. Keech (1934) listed it as B. gravida but it was re-identified (Donnelly $2000)$ as $B$. herbida. The normal range is hundreds of miles to the south.

\section{Celithemis - Small Pennants}

The two species are easily identified by their distinctive and colorful wing patterns

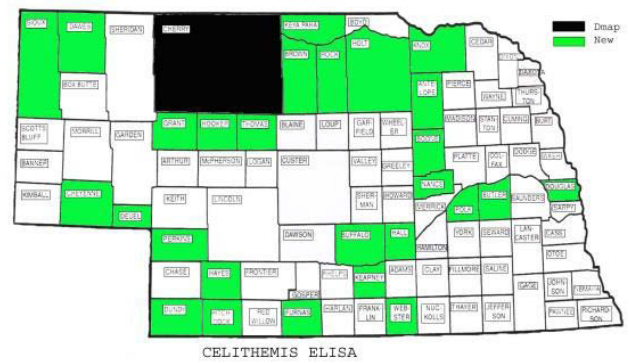

\section{Celithemis elisa (Calico Pennant)}

CR: 28, TL: 29-34mm, Spec: 1998, Pub: Beckemeyer, $1998 \mathrm{~b}$

FP: late June to late August - more common mid-July on.

Fairly common. This eastern species ranges west to central Texas, Oklahoma, eastern Kansas and western lowa. It was first collected in the state at the mid-July 1998 DSA meeting in Valentine, Cherry County, where numerous people collected 
specimens, but Hal White had an earlier sighting at Seneca, Thomas County, on July 21, 1991. A specimen from Rock County, 6 miles S of Bassett on July 24, 1999, is in the UNSM. No more were collected until this survey started, but there was only a sight record in the first year, 3 county records in 2006 and again in 2008, then 5 in 2009, 6 in 2010 and 1-3 new county records each year through 2014. This conspicuous and easily-collected species is one of the few that clearly represents a recent invasion. $C$. elisa is now known from 28 counties spanning the whole state and is reliable at some sites, although not at a majority. It is frequently found at borrow pit ponds along highways, and the construction of I-80, which produced many of these ponds, may have accelerated the invasion.

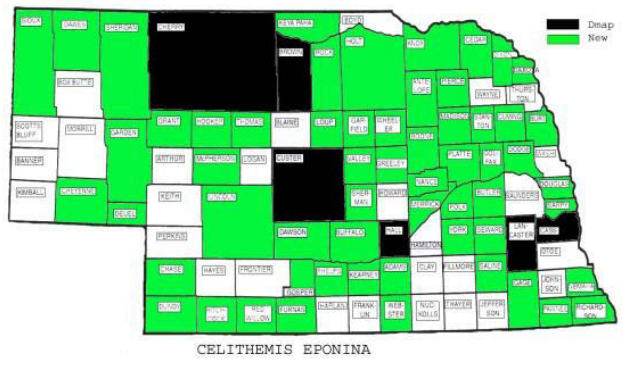

\section{Celithemis eponina (Halloween Pennant)}

CR: 65, TL: 36-42 mm, Spec: 1914, Pub: Keech, 1934

FP: late June to early September, more common mid-July on

Common. The range of this eastern species extends west to western Nebraska, Kansas and Oklahoma. It is statewide and to be expected in every county. It is more common later in the season and is found along rivers as well as ponds, but frequently in weedy vegetation well back from the water. Except for 13 collected July 31 and Aug. 2, 1914, in Cass County, there are no records prior to the 1990s. This is probably a recent invader like Celithemis elisa, as it is also conspicuous and unlikely to have been overlooked by earlier collectors.

\section{Dythemis - Setwing}

There is only one record of one species for the state.

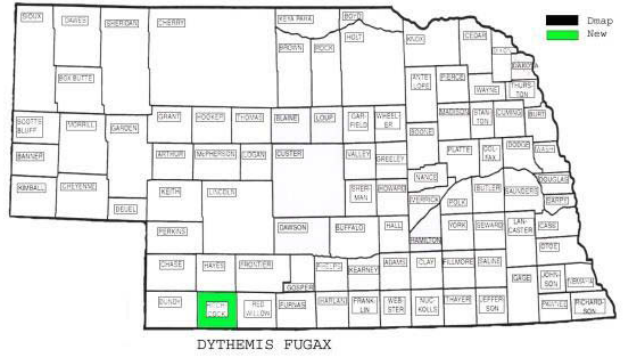

\section{Dythemis fugax (Checkered Setwing)}

CR: 1, TL: 44-50 mm, Spec: 2011 (IORI), Pub: Sibley $2011 b$

Accidental. In the US, it is mainly a Texas and Oklahoma species with scattered records in southern Kansas, New Mexico and Arizona. There is only one state record: a male collected in Hitchcock County, near Stratton, July 22, 2011. This individual was in a small pond separated from the Republican River by a thin dike, and it was being constantly harassed by the numerous Libellula and Tramea so that it would spend no more than a few seconds on each perch. Once flushed it went to the center of the pond, where it was not harassed, and would then fight back through the band of Libellula and Tramea, circling the edge of the pond, to again perch on some weed stalk. 


\section{Erythemis - Pondhawks}

There is only one very common pond species of the genus in the state. It is either blue (adult male) or bright green (young or female), and can be confused with the smaller, but also blue, Pachydiplax (Blue Dasher).

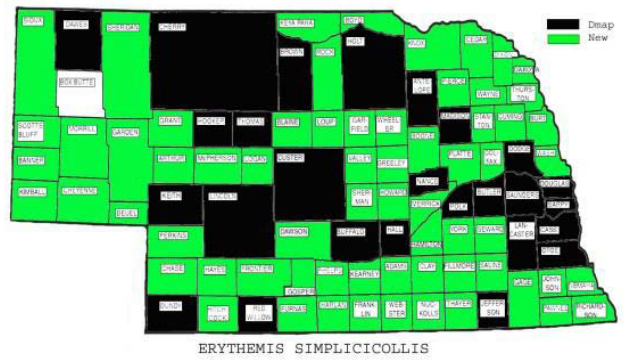

\section{Erythemis simplicicollis (Eastern Pondhawk)}

CR: 92, TL: 38-44 mm, Spec: 1911, Pub: Keech, 1934

FP: late May to mid-September

Very common. This eastern species has been recorded from every county except Box Butte and is replaced by the similar E. collocata (Western Pondhawk) in eastern Colorado. No E. collocata have been found in Nebraska or bordering counties of Kansas, Colorado and Wyoming, and $E$. simplicicollis is rare to uncommon in most of the western Nebraska counties. There are no eastern Wyoming records of either species. This pond species is often more common in marshy vegetation away from a pond or stream. It can easily be confused with Gomphurus by beginning odonate watchers, as it may perch flat on the ground in a path as Gomphids frequently do.

\section{Leucorrhinia - Whitefaces}

There is only one species of this genus found in Nebraska. The bright white face is diagnostic for the genus, but the black abdomen with a yellow spot will pin down the ID.

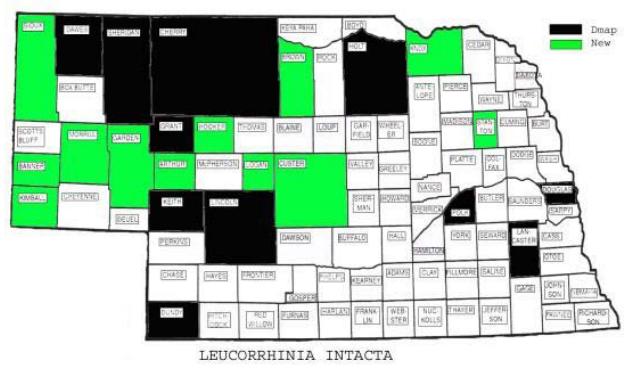

Leucorrhinia intacta (Dot-tailed Whiteface)

CR: 23, TL: 29-33 mm, Spec: est. 1913, Pub: Pruess, 1967

FP: mid-May to mid-August

Fairly common. This transcontinental northern species is most regular in the western half of the state and particularly in more northern counties. The Midwestern gap is pronounced in this species. L. intacta is found in all but two lowa counties bordering Nebraska, but there are only 6 records in 55 eastern Nebraska counties. Only two of these records are recent and both represent single females. In the western counties they are sometimes common or abundant, as they were on July 20, 2011, at Island Lake in Crescent Lake NWR, Garden County, and July 5, 2011, at a pond on Diamond Bar Ranch, 3 miles north of Stapleton, Logan County. Usually one finds a few individuals in marshy areas or at marshy edges of ponds. 


\section{Libellula - King Skimmers}

The 5 species of Libellula and 2 of Plathemis (formerly in Libellula) are large, distinctly patterned dragonflies. L. Iuctuosa and L. pulchella (together with Plathemis lydia), have been recorded in every county and are frequently found together at ponds or slow streams and backwaters, but there are pond habitats where only one is expected or is at least the most abundant. Three other species of this group are western and the last species is known from a single record.

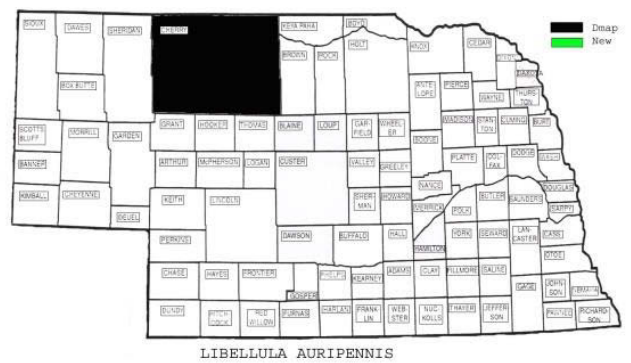

Libellula auripennis (Golden-winged Skimmer)

CR: 1, TL: 45-58 mm, Spec: 1960, Pub: Donnelly, 2000a

Accidental. This is a southeastern species found no closer than eastern Oklahoma. The only state record is a young male collected at Fort Crowe Ranch south of Valentine, Cherry Co., on Sept. 30, 1960, by W. T. Atyeo. Originally identified as L. flavida (Pruess, 1967), it was re-identified by Donnelly (2000a).

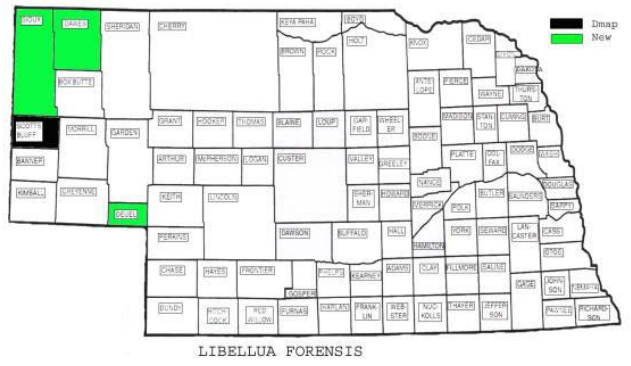

\section{Libellula forensis (Eight-spotted Skimmer)}

CR: 4, TL: 49-51 mm, Spec: 1913, Pub: Keech, 1934

FP: mid-June to late July

Rare. This western species barely reaches western Nebraska. It is recorded from 3 northwestern counties plus Deuel County in the southeast corner of the Panhandle. It is a pond species found in the same pond habitat with the common Libellula and Plathemis, and it is very possible that all records are of temporary invasions. It was common at a pond next to the Hudson-Meng Bison Kill site July 17, 2011, in Sioux County but was not found there in the following years. In Scotts Bluff County, L.M. Gates collected specimens June 13, 1913, and June 15, 17, 22, 23 of 1915. Since we did not find it in Scotts Bluff County during our survey, one wonders if it was more common when Gates was collecting or if it was sporadic, since he did not collect it in 1914 and the 1915 collecting would suggest it was a desired species. The Dawes County record by H.R. Lawson in 1979 was the only specimen he had from a Chadron College nature center where he spent several summers. The Deuel County record is a 2011 Dennis Paulson photograph of a single individual at a site we had visited in 3 previous years.

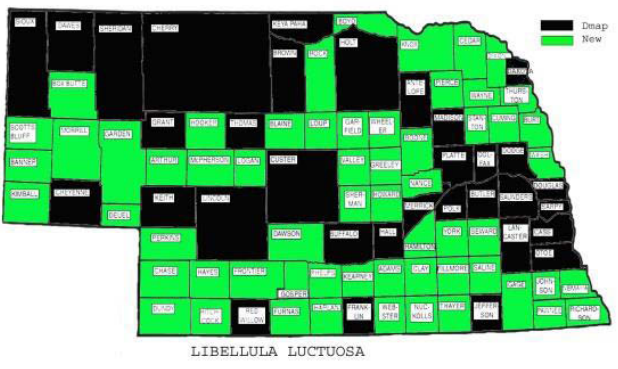

Libellula luctuosa (Widow Skimmer)

CR: 93, TL: 42-50 mm, Spec: 1910, Pub: Keech, 1934

FP: late May to early September 
Very common. This is primarily an eastern pond species, but it is common along the Pacific coast with records in southern Arizona and New Mexico to Texas. Nebraska is close to the western edge of the eastern range. It is often abundant at ponds but also found along slowmoving streams. It is less common in the more seasonal or degraded habitats where one still finds L. pulchella and Plathemis lydia. For unknown reasons, one frequently finds teneral specimens of this species but not $L$. pulchella or Plathemis lydia near ponds. The large black basal marks on the wings are bordered by white distally. Many females in Nebraska have black tips to their wings with as much as one-quarter inch of the tip being black.

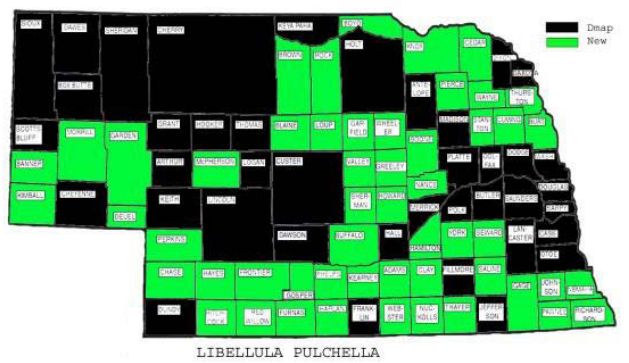

Libellula pulchella (Twelve-spotted Skimmer)

CR: 93, TL: 52-57 mm, Spec: 1912, Pub: Keech, 1934

FP: late May to late August

Very common. A transcontinental species found in many habitats. It is the most widespread of the Nebraska Libellula, the first species recorded from all 93 counties and the most common species in Nebraska Dot Map records. It is frequently the only Libellula in drying seasonal wetlands and it is regularly found well away from water in shelter belts. It characteristically flies at considerable heights, out of net range, over wetlands or fields.

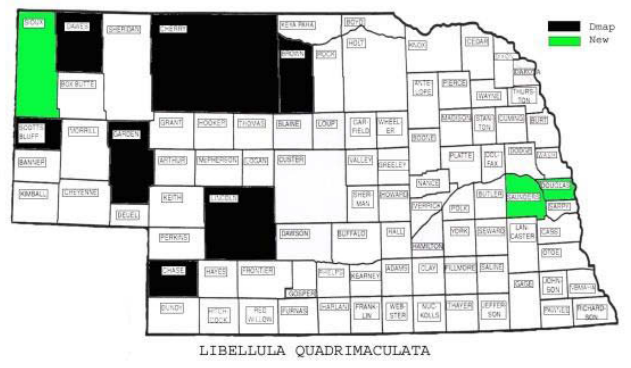

Libellula quadrimaculata (Four-spotted Skimmer)

CR: 10, TL: 42-46 mm, Spec: 1914, Pub: Keech, 1934

FP: early June to late July

Rare. This more northern transcontinental species has a decided Midwestern gap through eastern Nebraska, South and North Dakota. There are scattered records in the western half of the state but it was not recorded in the eastern part of Nebraska until 2013. Brian Peterson found large numbers (some laying eggs) for a few days in late June at sites in Douglas and Saunders County. These are the only Nebraska records in the eastern half of the state, although it is regular in lowa. This pond species is usually found in marshy cattail areas.

Pachydiplax - Blue Dasher - The color at the base of the wings and a black tip to the abdomen separate this small, blue and widespread species from Erythemis (Pondhawk).

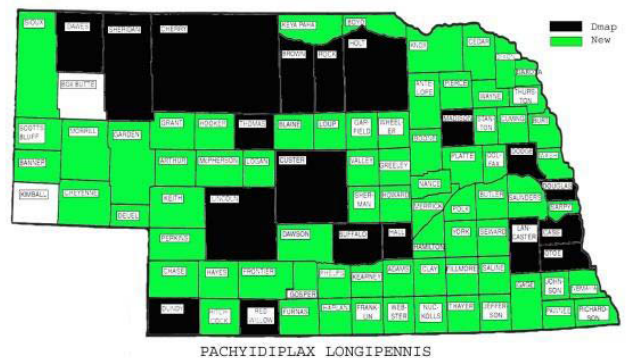

Pachydiplax longipennis (Blue Dasher)

CR: 91, TL: 28-45 mm, Spec: 1913, Pub: Keech, 1934

FP: mid-May to mid-September 
Very common. This transcontinental species is mainly absent from the Great Basin, so Nebraska is on the northern and western edge of the range. It is missing from two far western counties, unrecorded from Wyoming and difficult to find in many western counties. It is found in a variety of pond situations from irrigation sumps to large ponds. It is partial to cattail edges in these ponds and particularly to open water between the shore and a cattail edge.

\section{Pantala - Rainpool Gliders}

There are two sometimes common species in this genus and both are irruptive migrants from the south. $P$. flavescens is a yellowish, very distinctive large-headed species. $P$. hymenaea is darker but similar, with a black patch at the base of each hind wing (difficult to see). Both hang vertically when perched and spend much time gliding over fields and parking lots. Eggs are laid in temporary ponds and puddles and hatch out very rapidly.

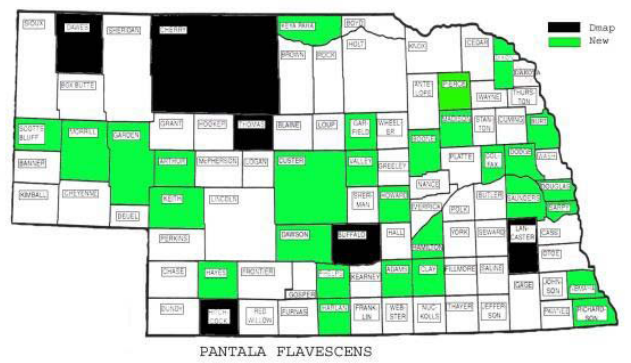
rapidly so one finds teneral individuals in July and August. Nebraska is at the northern edge of the US range of this worldwide species, but it should be recorded in all counties. We have rarely seen large numbers or great swings in abundance from one year to the next. It is usually found flying slowly at various elevations over fields or even parking lots, but egg laying is in temporary ponds and puddles.

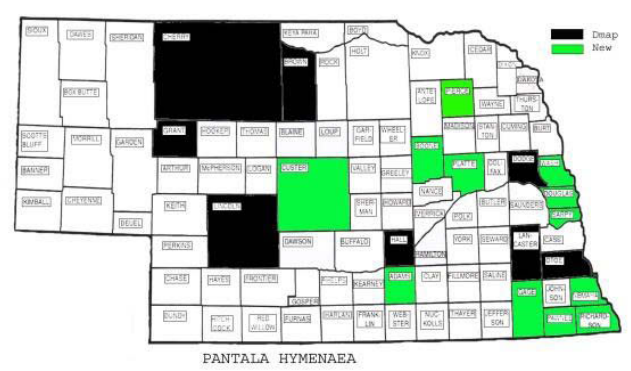

\section{Pantala hymenaea (Spot-winged Glider)}

CR: 20, TL: 45-50 mm, Spec: est. 1915, Pub: Keech, 1934

FP: late June to early September

Uncommon. This is another summer invader, but there are definite irruption years and years with almost none. This is also a transcontinental species and Nebraska is at the northern and western edge of the Midwestern range. Its habits are essentially identical to $P$. flavescens, but it is darker than that species with a dark spot at the base of each hindwing (often hard to discern).

\section{Perithemis - Amberwing}

This is the smallest dragonfly in Nebraska and the only one with amber wings. 


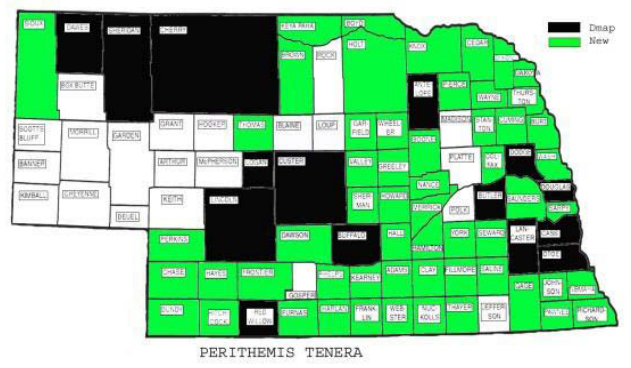

\section{Perithemis tenera (Eastern Amberwing)}

CR: 73, TL: 20-25 mm, Spec: 1914, Pub: Keech, 1934

FP: early June to late September

Common. This is an eastern species reaching its western limit in Nebraska and absent from a number of southern Panhandle and southwestern counties. It is found flying very low over ponds and lakes where it perches on almost any emergent material, but it is also common at badlydegraded duck ponds in city parks where Enallagma civile may be the only other odonate. This tiny orangish dragonfly with amber wings should not be confused with any other odonate. Although difficult to catch because they fly so low to the water, a net lowered slowly from above does not seem to frighten perched individuals.

\section{Plathemis - Whitetails}

These are similar to the equally common Libellula pulchella and L. luctuosa, but both species of Plathemis have white tails. P. Iydia has a large prominent black band on the outer half of wing. $P$. subornata has white between this and the small black spot at the base of the wing.

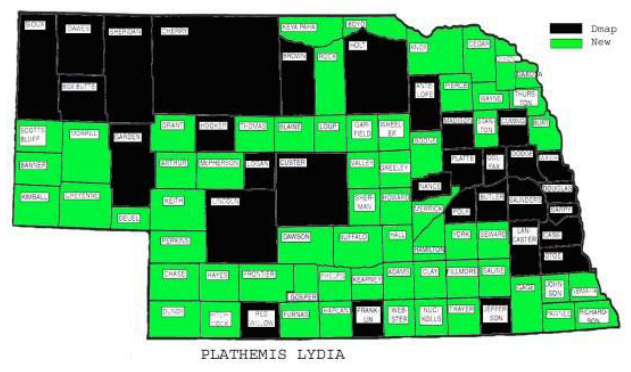

\section{Plathemis lydia (Common Whitetail)}

CR: 93, TL: 42-48 mm, Spec: 1909, Pub: Keech, 1934

FP: mid-May to mid-September

Very common. Nebraska is on the western edge of the eastern form's range and the species is difficult to find in far western counties. This species inhabits a variety of ponds and still water habitats and is often found in shallow, muddy ponds and muddy backwaters of large rivers mostly avoided by the other large skimmers. Unlike Libellula luctuosa and L. pulchella, it is often more abundant just back in the cottonwoods away from the water. Immatures and females will be mixed in with the adult males resting on fallen cottonwood trunks or on areas of bare ground. One year Kilpatrick Lake (Box Butte County) was so dry there was not even wet mud in the center, yet there were still 10-15 M \& F Whitetails in the brushy growth around the edge.

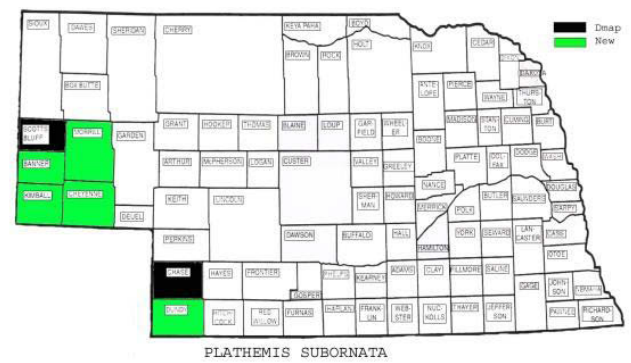

Plathemis subornata (Desert Whitetail)

CR: 7, TL: 40-51 mm, Spec: 1913, Pub: Keech, 1934

FP: early July to late July 
Uncommon. This western replacement for $P$. lydia is at the northern and eastern edge of its range in Nebraska but is present in subsequent years at sites where collected. It is frequently found with $P$. lydia but is more common in narrow, stagnant or slow-moving streams where the grass almost meets over the stream, a habitat where $P$ lydia is not found. At any place where the stream widens, one finds both species interacting.

\section{Sympetrum - Meadowhawks}

Eleven members of this large genus have been found in Nebraska. We lump S. occidentale with $S$. semicinctum. Two species are accidental and two just reach the western edge of the state, but the other seven are all common and sometimes incredibly abundant. All males of the species are reddish, some very red, and of moderate size. Immature individuals are yellowish for an extended period and are frequently found in large numbers away from the water. $S$. obtrusum is the most common species in gatherings with S. internum, S. rubicundulum and $S$. semicinctum. These gatherings of young individuals in July are an impressive sight, with numbers of individuals running from the hundreds toward infinity. In some swarms checked in Custer and Logan County, females outnumbered males 8 to 1.

Sympetrum internum/S. obtrusum/S.rubicundulum are very similar and all three have varying amounts of color at the base of the wings. All male $S$. rubicundulum have a large orangeish basal patch that extends half way out the wing (to the nodus). S. obtrusum males have a millimeter or two of color at the base of the wing (to the anal loop) and $S$. internum is similar, although a few may have a fainter patch of color of similar size to S. rubicundulum. Females of all three species may have enlarged basal markings but this varied from the majority of $S$. rubicundulum females having basal markings going to the nodus, to $40 \%$ of $S$. obtrusum and $20 \%$ of S. internum (i.e. visually identical with S. rubicundulum). It is possible the female markings fade with age, as a high percentage of young female S. obtrusum had color to the nodus and none of the females in pairs had color past the anal loop.

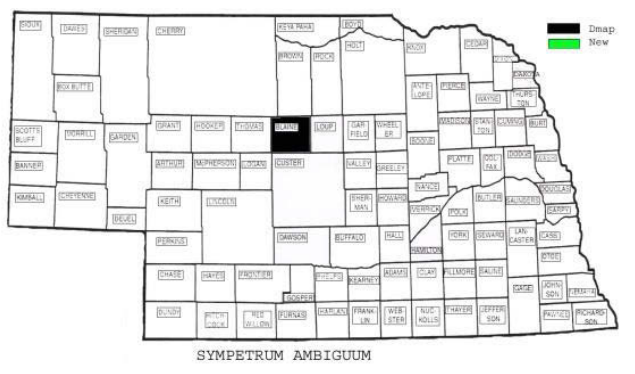

\section{Sympetrum ambiguum (Blue-faced Meadowhawk)}

CR: 1, TL: 36-38 mm, Spec: 1969 (IORI), Pub: Bick \& Hornuff, 1972

Accidental. This southern and eastern species reaches its northern and western limits in central Kansas. There is only one state record (IORI-GB872): a male collected by George Bick on July 18, 1969, in Blaine County 5 miles east of Brewster in a boggy area along the Loup River. This record is some 200 miles north of records in Kansas and a similar distance northwest of records in northwest Missouri. 


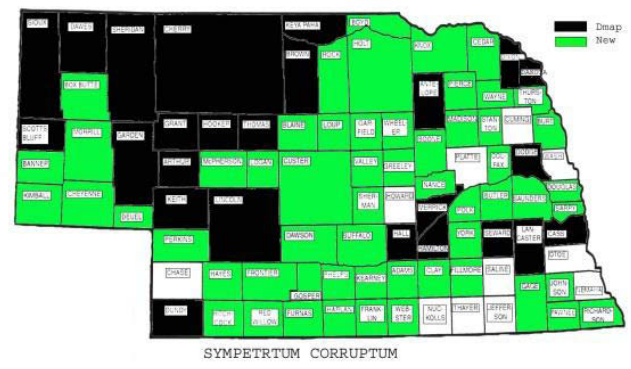

\section{Sympetrum corruptum (Variegated Meadowhawk)}

CR: 82, TL: 32-43 mm, Spec: 1905, Pub: Keech, 1934

FP: mid-April to mid-October (some mid-March records in UNSM)

Common. This, our largest Sympetrum, is a western species ranging east commonly to Ohio, with vagrant records in almost all states. It is, as a migrant from the south, one of the first odonates to appear in the Spring and one of the last to be seen in the Fall. It can be expected in every Nebraska county and is potentially present at almost any pond or lake. Small seasonal cattle ponds and large reservoirs seem equally attractive, but we have only occasionally found it in large numbers.

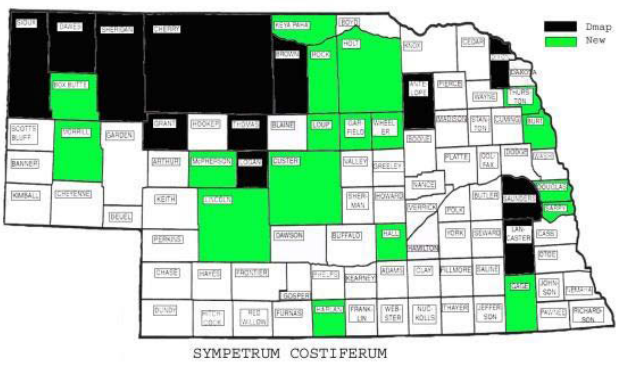

\section{Sympetrum costiferum (Saffron-winged Meadowhawk)}

CR: 30, TL: 31-37 mm, Spec: 1899, Pub: Keech, 1934

FP: late June to mid-October

Common. This northern transcontinental species appears in late June but is primarily a late season species and is the dominant Sympetrum in September and October. It is more common in northern and western Nebraska, but there are scattered records in southern and eastern Nebraska as well as northern Kansas. The favored habitats are vegetated roadside ditches, cattail borders of ponds and marshy areas back from streams. At Heron Haven, Douglas County, October 20, 2012, it outnumbered the S. vicinum by four to one with numerous egg laying pairs.

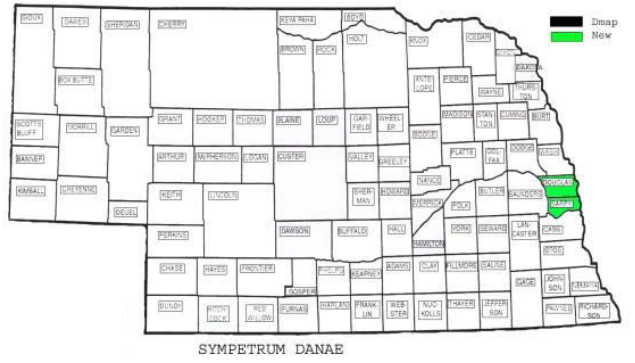

\section{Sympetrum danae (Black Meadowhawk)}

CR: 2. TL: 21-23 mm, Spec: 2012 (IORI), Pub: Padelford \& Schmid, 2012

Vagrant. An invasion of this species into Nebraska and lowa in 2012 resulted in records from Sarpy and Douglas Counties. This is a northern transcontinental species, with Wisconsin having the closest population to Nebraska. It was first recorded in the late fall of 2012 when individuals were found at Fontenelle Forest, Sarpy County, by Rick Schmid on Sept. 21, and at Heron Haven, Douglas County, on Sept. 22 by Brian Peterson (Padelford and Schmid, 2012). There were also reports from lowa. They were found in shallow, vegetation-clogged borders of small ponds. The individuals at both sites were reported in wheel or egg laying, and those at the latter site were present to at least Oct. 21 . They were not found in 2013 despite frequent checks at both sites. 


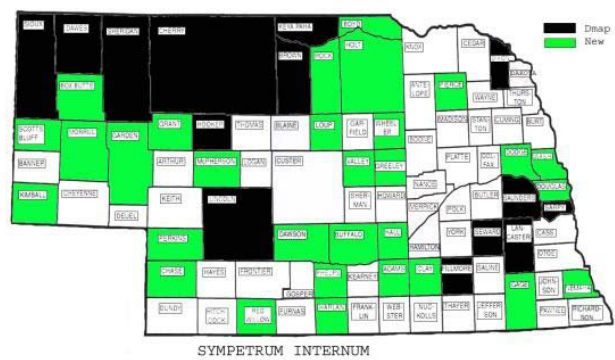

\section{Sympetrum internum (Cherry-faced Meadowhawk)}

CR: 44, TL: 21-36 mm, Spec: 1911, Pub: Muttkowski, 1910

FP: early June to late September

Fairly common. This transcontinental species is almost at the southern edge of its range in Nebraska as are the two very similar species (S. obtrusum and S. rubicundulum). It is locally common in some northern and western counties, but it is always much less common than S. obtrusum and slightly rarer than S. rubicundulum. Late in the season, when those two species are rarely found, it is a more conspicuous species around ponds and in marshy habitats.

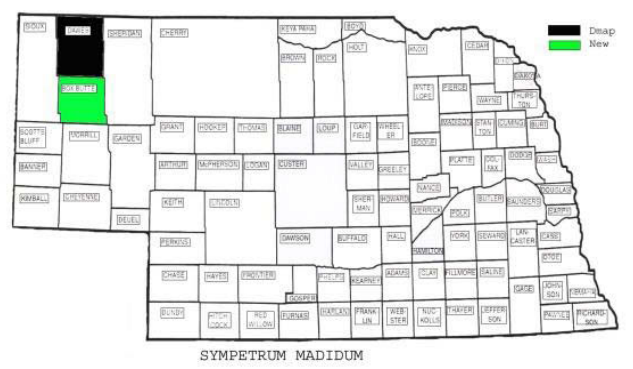

\section{Sympetrum madidum (Red-veined Meadowhawk)}

CR: 2, TL: 42-45 mm, Spec: 1966 (Chadron State College), Pub: Moody, 1967

FP: early July into August.

Rare. This west coast species has a spotty distribution east to North Dakota and Nebraska. The only records in Nebraska are from the northwest Panhandle counties of Dawes and Box Butte Counties. It was fairly common in wet areas back from the Niobrara River in Box Butte County south of Marsland on July 2, 2010, and it was collected north of Chadron, Dawes County, at the White River on Aug. 1, 1966, by D. Moore. This species is probably not present every year.

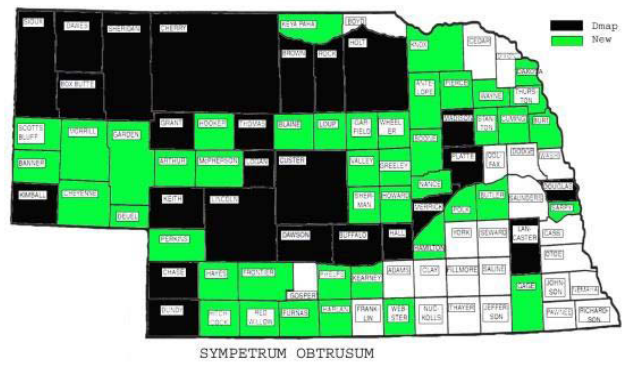

\section{Sympetrum obtrusum (White-faced Meadowhawk)}

CR: 69, TL: 31-39 mm, Spec: 1908, Pub: Keech, 1934

FP: early June to mid-September

Common. S. corruptum is more widespread but this is the most abundant Sympetrum in the state. Young individuals are often found in huge numbers mixed with other young Sympetrum. This is a slightly northern transcontinental species with Nebraska near the southern limit for the species. It is decidedly less common in southern counties than northern ones and not yet found in a number of counties in the southeastern part of the state. It is a species of grassy pond edges, marshy areas and wet areas near streams. A typical emergence was seen at Ambler Lake (west of Stapleton, Logan County) on July 3, 2009. From field notes: "No activity over water so I walked through tall grass and field edges flushing odonates. A super abundance of $S$. obtrusum with a few S. rubicundulum present." At the 1998 DSA meeting in Cherry County everyone 
remarked on the incredible numbers of young Sympetrum (mostly S. obtrusum) in the fields and on the barbed wire fence lines. In two swarms of immatures we sampled, females made up over $80 \%$ of the individuals.

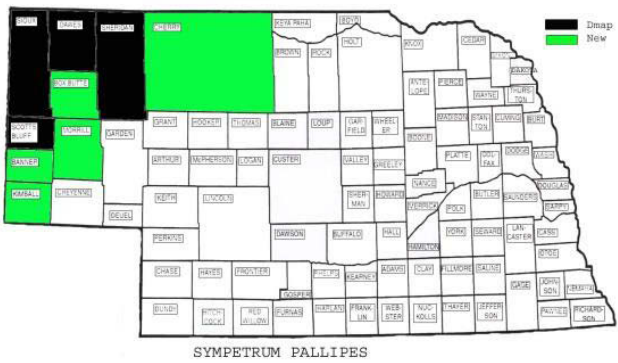

\section{Sympetrum pallipes (Striped Meadowhawk)}

CR: 9, TL: 34-38 mm, Spec: 1912, Pub: Keech, 1934

FP: early July to late August

Uncommon. This western species, like S. madidum, just reaches western Nebraska but is much commoner than S. madidum. Unlike S. madidum, it is usually present at the same sites the following year. It is often locally abundant in counties where found and is a typical Sympetrum of slow, almost stagnant, streams, ponds, and marshy areas. Teneral individuals can be confused with teneral S. corruptum, although S. pallipes is smaller.

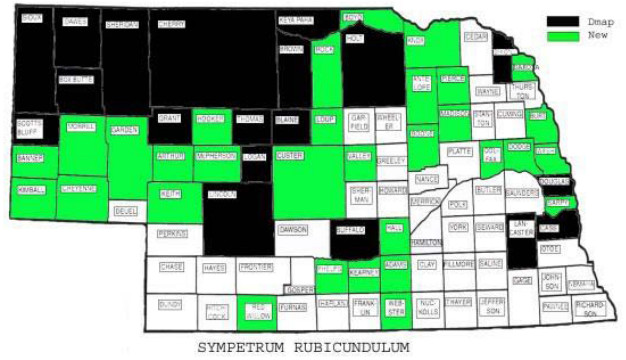

Sympetrum rubicundulum (Ruby Meadowhawk)

CR: 49, TL: 33-41 mm, Spec: 1912, Pub: Keech, 1934

FP: late June to mid-September

Common. This eastern and slightly northern species is mostly absent south and north of Nebraska in Kansas and South Dakota, and there is only one record from eastern Wyoming. It is markedly less common in central eastern counties and absent from almost all the southern tier counties. In males and a majority of females, the basal wing marking extends to the nodus or beyond in both front and hind wings, although it is not as vivid in females. This makes males look superficially like $S$. semicinctum but without the darker band at the distal end of the basal patch. Specimens with these markings were formerly called S. assimilatum and those in the eastern US without these extensive basal markings were called S. rubicundulum. Keech used both names in his thesis but did not mention internum, and we assume his $S$. rubicundulum = the present $S$. internum and his $S$. assimilatum = the present $S$. rubicundulum.

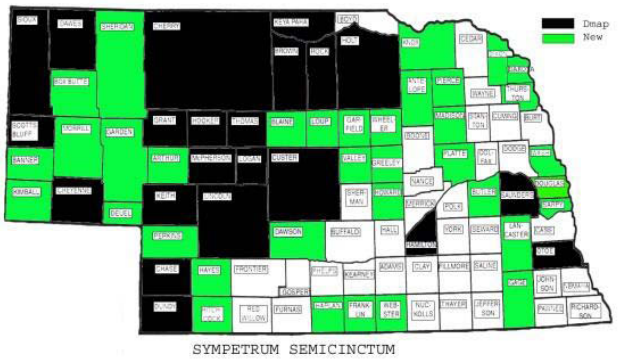

\section{Sympetrum semicinctum (Band-winged Meadowhawk)}

CR: 58, TL: 24-40 mm, Spec: 1905, Pub: Keech, 1934

FP: mid-May to mid-October

Common. Although a transcontinental species, to be expected in all the counties, occurrence is spotty in southern and eastern areas. It is more likely 
in marshy areas than open pond edges, although it can be found at both sites and is often locally abundant. The species is frequently in woods and shelter belts miles from water and regularly flies high above the fields, in contrast to New York individuals that fly just above or in the vegetation.

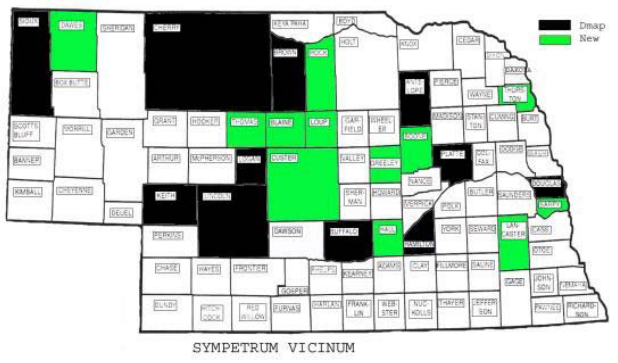

\section{Sympetrum vicinum (Autumn Meadowhawk)}

CR: 24, TL: 31-35 mm, Spec: 1905, Pub: Keech, 1934

FP: early July to mid-October

Uncommon. This is a transcontinental pond species with west coast and eastern populations. The eastern population reaches the western edge of its range in western Nebraska and for all practical purposes its southern limit - there are no records from the southern two tiers of Nebraska and only 5 records in Kansas. The scarcity of records for this late season species probably reflects the absence of collecting when the species is most abundant. S. vicinum and S. costiferum are the only Sympetrum likely to be found in Nebraska in October and S. costiferum is more widespread and abundant than S. vicinum at that time.

\section{Tramea - Saddlebags}

The large size and large basal wing patch should identify all members of this genus. T. lacerata has black basal markings, the other two red.

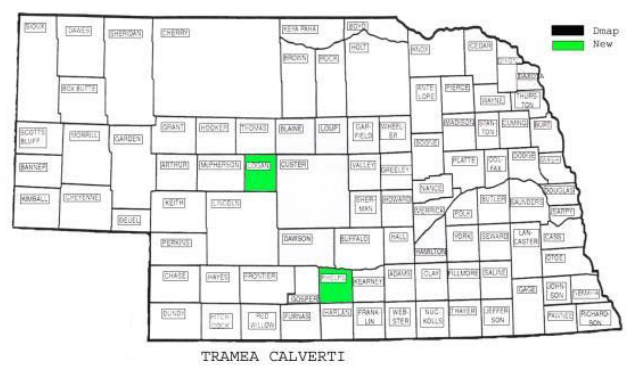

\section{Tramea calverti (Striped Saddlebags)}

CR: 2, TL: 45-49 mm, Spec: 2010, Pub: Sibley, 2011a

Accidental. This is a Central and South American species with a population in south Texas and numerous vagrant records, mostly in the eastern US. During an exceptionally wet year, single males were collected June 23, 2010, at the Sacramento-Wilcox SWMA, Phelps County, and on July 4, 2010, at Ambler Lake near Stapleton, Logan County. It was also an exceptional year for $T$. onusta and at both sites the two were intermixed. The Phelps County record was collected in a net swing that also netted two $T$. onusta. This species can easily be confused with the similar $T$. onusta.

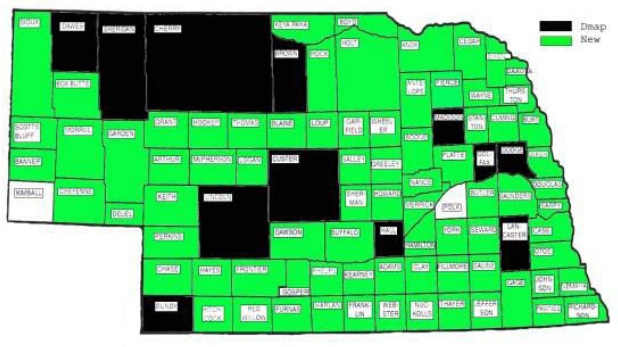

Tramea lacerata (Black Saddlebags)

CR: 91, TL: 51-55 mm, Spec: 1911, Pub: Keech, 1934

FP: late May to early October 
Common. This transcontinental species has been found in all but Polk and Kimball counties. It is often seen patrolling the edges of ponds and lakes a few feet above the water or, almost as frequently, hawking insects over fields. It is frequently found in shelter belts, groves or even single trees far from water. Rarely does one find more than a few individuals at a site.

Surprisingly, there is only one sight record from eastern Wyoming although this conspicuous species is relatively common in the bordering counties of Nebraska.

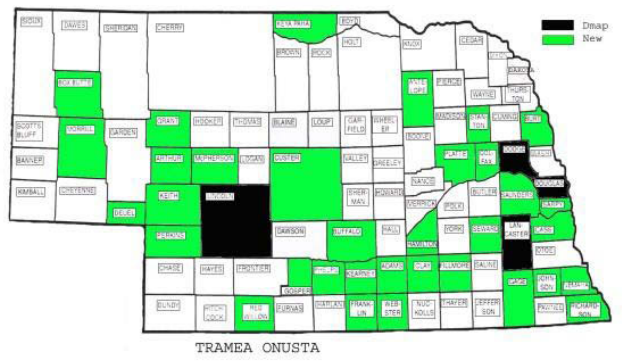

\section{Tramea onusta (Red Saddlebags)}

CR: 38, TL: 41-49 mm, Spec: 1912, Pub: Keech, 1934

FP: mid-May to late September

Uncommon. Nebraska is on the northern edge of the range of this transcontinental species. In normal years

they are rare and seeing more than one or two at a pond is unusual. During the exceptionally wet year of 2010 they were common everywhere we visited and equal to or greatly outnumbering the $T$. lacerata. With enough collecting and photographing in irruption years it will be recorded in all the counties of Nebraska. Its habits are the same as for T. lacerata.

\section{ACKNOWLEDGEMENTS}

During 15 trips to Nebraska during this study we have been assisted by too many people to mention individually, but all of them are important. Among these are the huge number of landowners who have allowed us to chase odonates on their property, the people in the Nebraska Game and Parks Commission who have been uniformly helpful at parks, state recreation areas, and wildlife management areas, answering email queries and issuing permits, the entomology section of the State Museum at the University of Nebraska, particularly Mary Liz Jameson and Bret Ratcliffe for allowing us use of the collections, and many other Nebraska residents who have assisted our efforts in diverse ways.

Roy Beckemeyer, Nick Donnelly and Dennis Paulson, perhaps unknown to them, launched this study and have, like Bill Mauffray and Steve Hummel, been very supportive. Loren and Babs Padelford (primarily Sarpy County) found several state records before this study, Don and Janis Paseka (Dodge County) became active odonate observers and maintain, through UNSM, a regularly updated web site on the odonates of Nebraska. Brian Peterson (Douglas County) has been very active since 2012 and valuable in providing regular reports from the Heron Haven Nature Center; Matt Brust (Dawes County) has similarly provided information from the NW corner of the state. Thomas Donnelly (adult specimens) and Ken Tennessen (larval material) have been generous with their time and invaluable in identifying difficult species. Many other collectors have provided field notes, access to collections, and locality information. Gloria Correa provided the Spanish translation of the Abstract. 


\section{REFERENCES}

Beckemeyer, R. 1997a. Some Midwestern odonata records for 1997. Argia 9(4):6

Beckemeyer, R. 1997b. Some Nebraska odonata specimens in the University of Nebraska Lincoln insect collection. Argia 9(4):7

Beckemeyer, R. 1998a. A brief history of the Plains Emerald - Somatochlora ensigera. Argia 10(1):17-20.

Beckemeyer, R. 1998b. Nebraska and South Dakota Odonata - A compilation of collecting reports related to the July 1998 Valentine, Nebraska annual meeting of the DSA. Argia 10(4):27-28

Beckemeyer, R. 1999a. Annotated checklist of Nebraska Odonata (Dragonflies and Damselflies). Unpublished list of Zygoptera.

Beckemeyer, R. 1999b. List of Nebraska Anisoptera county records. unpublished list.

Beckemeyer, R. 1999c. Ischnura barberi Currie 1903 - "A salty fork-tale". Argia 11(1):22-23

Beckemeyer, R. 2000. Some county odonata records for Kansas and Nebraska for 1999 and 2000. Argia 12(3):27-28.

Beckemeyer, R. 2001. Some Great Plains Odonata records for 2000 and 2001 Argia 13(4):7-8.

Beckemeyer, R. 2002. Odonata in the Great Plains states: patterns of distribution and diversity. Bull. Am. Odonatology 6(3):49-99.

Beckemeyer, R. and S. Hummel. 1997. The Dragonfly Society of the Americas' 1998 annual meeting to be held in Valentine, Nebraska, July 17-19. Argia 9(3):7-11.

Beckemeyer, R. and S. Hummel. 1998a. Could Valentine, Nebraska be Odonata heaven? The 1998 Dragonfly Society of the Americas annual meeting. Argia 10(3):4-6.

Beckemeyer, R and S. Hummel. 1998b. Two notes on Somatochlora ensigera, the plains emerald. Argia 10(4):28-30

Bedell, P. 2001. Some recent odonate records for Nebraska, Argia 13(2):2

Bick, G.H. and L.E. Hornuff. 1972. Odonata collected in Wyoming, South Dakota, and Nebraska. Proc. Ent. Soc. Wash. 74 (1):1-8

Clopton, R.E., T.J. Percival and J. Janovy, Jr. 1993. Nubenocephalus nebraskensis n. gen., n. sp. (Apicomplexa: Actinocephalidae) from adults of Argia bipunctulata (Odonata: Zygoptera). J. Parasitology 79(4):533-537

Donnelly, T. Western collecting trip - 1991. 1991. Argia 3(3):11.

Donnelly, T. 200a. Disjunct Odonata records - The agony and the ecstasy. Argia 12(1):7-8

Donnelly, T. 200b. Dot Map Project - Hung up on Lestes. Argia 12(3):31-32.

Donnelly, T. 2004a. Distribution of North American Odonata. Part I. Aeshnidae, Petaluridae, Gomphidae, Cordulegasteridae. Bull. Am. Odonatology 7 (4):61-90.

Donnelly, T. 2004b. Distribution of North American Odonata. Part II. Macromiidae, Corduliidae, Libellulidae. Bull. Am. Odonatology 8(1):1-32.

Donnelly, T. 2004c. Distribution of North American Odonata. Part III. Calopterygidae, Lestidae, Coenagrionidae, Protoneuridae, Platystictidae, with data sources and bibliography. Bull. Am. Odonatology 8(2-3):33-99.

Keech, Charles F. 1934. The odonata of Nebraska. M.S. thesis, University of Nebraska - Lincoln. January $1,1934.53 p p$ 
Johnsgard, P. 2001. The Nature of Nebraska. Ecology and biodiversity. Lincoln. University of Nebraska Press. 402pp

Kormondy, E.J. 1957. Records of western Odonata with notes on Amphiagrion abbreviatum (Selys). J. Kansas Ent. Soc. 30(3):108-110.

Kormondy, E.J. 1960. New North American records of anisopterous Odonata. Ent. News, 71(5):121-130.

Montgomery, B.E. 1967b. Geographic distribution of the Odonata of the north central states. Proc. North Central Branch - Ent. Soc. Am. 22:121-129.

Moody. 1967. D.L. A study of the odonata in northwestern Nebraska. M.S. Thesis, Chadron State College, Chadron, NE. October 1967. 1-37pp.

Muttkowski, R.A. 1910. Catalogue of the odonata of North America. Bulletin of the Public Museum of the city of Milwaukee. Vol. 1, Article 1 - pages 18, 92, 93, 160.

Needham, J.G. and H.B. Heywood. 1929. A Handbook of the Dragonflies of North America. Springfield. Charles C. Thomas. 378pp

Needham, J.G. and M.J. Westfall, Jr. 1955. A Manual of the Dragonflies of North America (Anisoptera). Berkeley. Univ. Calif. Press, 615pp.

Needham, J.G., M.J. Westfall, Jr. and M.L. May. 2000. Dragonflies of North America.

Gainesville. Scientific Publishers. 940pp

Padelford, L and B, R. Schmid. 2012. First report of Black Meadowhawk (Sympetrum danae) for Nebraska. Argia 24(4):13.

Paulson, D. 2003. Where to go on your next dragonfly trip. Argia 14(4): 20-21

Peterson, B. 2014. Dromogomphus spoliatus (Flag-tailed Spineyleg) Confirmed in Nebraska. Argia 26(3):23-24

Pruess, N.C. 1967. Checklist of Nebraska Odonata. Proc. N. Cen. Branch - Ent. Soc. Am. 22:112 Sibley, F.C. 2006a. Nebraska summer. Argia 17(4):8-10

Sibley, F.C. 2006b. Nebraska revisited. Argia 18(3):14-16

Sibley, F.C. 2011a. New species for Nebraska. Argia 23(1):20-21

Sibley, F.C. 2011b. Nebras summer and Dythemis fugax (Checkered Setwing). Argia 23(4):27-29

Sibley, F.C. 2014a. A short history of odonate collecting in Nebraska. Argia 26(1):23-28

Sibley, F.C. 2014b. Notes from Wyoming and Nebraska. Argia 26(3):24-26.

Troelstrup, N.H., Jr., G.L. Hergenrader, and K.P. Pruess. 1985. Neurocordulia molesta

(Walsh) (Odonata: Corduliidae): A new record for NE and SD. J. KS Ent. Soc. 58(4):721. Uhler, P.R. 1857. Contributions to the Neuropterology of the United States. No. 1:p 87-88 - In Synopsis of the described Neuroptera of North America. July 1861, Smithsonian Miscellaneous Collections. Vol. IV, Washington, D.C. 


\section{APPENDIX A - GAME AND PARKS REGIONS}

The six regions used by the Game and Parks commission: Northeast (NE), Southeast (SE), Sandhills (SA), Southcentral (SC), Panhandle (PA) and Southwest (SW), are discussed below with emphasis on counties and odonate sites productive during the 2005-2014 survey. See Map 5 for region boundaries.

Pointing one to site $X$ in order to find species $Y$ is difficult in Nebraska because of differences from drought years to wet years and changes in management of a site. In the following discussion of the six regions, we have included brief comments on odonate collecting sites. At the end we have listed counties in two categories. 1. Counties where our recommendations would be no better than you looking at Google Earth or the DeLorme Atlas. 2. Counties where sites are less likely to change dramatically in the future. These recommendations (?) are based on only a few visit but will hopefully be helpful.

Nebraska is mainly populated by highly adaptable species, able to reinvade quickly in wet years or able to tolerate low oxygen levels and/or agricultural runoff. The 55 commonest species make up $85-86 \%$ of the county records and over half the counties (mainly heavily farmed areas) have only zero to two species from the 55 less common species.

\section{NORTHEAST}

This area of rolling hills, loess overlaying glacial deposits, is mainly crop land bounded on the east and north by the Missouri River, on the south by the Platte River and on the west by Sandhills. The eastern-most counties of this region are similar to lowa, but there is a decided change from western lowa that is hard to describe. Permanent ponds, regular on the lowa side, are less common, less permanent and less vegetated. The area seems much drier, even on the eastern boundary, than in western lowa, although the rainfall totals would not support this. The westernmost counties of the region are decidedly drier prairie habitat.

South Sioux City on the Missouri, Fremont and Columbus on the Platte and Norfolk in the center are the major cities, but have populations of only 13-27 thousand. The 10,590 square mile region has a population density of 22.8 people per square mile, with Boyd County being the least populated - 3.7 per square mile. Most of the counties were established in the 1850s and, like lowa and half of Nebraska, have a road on almost every section line.

Fremont Lakes SRA, Dodge County, is the only really outstanding site in this region. The section of the park between the railroad and Highway 30 has a great diversity of borrow pit lakes and is little disturbed, very productive for odonates and used primarily for fishing. The main section of the park has very heavy recreational and boat use with a reduction in shore line vegetation and odonates. Other sites with a fair variety of species and providing Missouri River access are Ponca SP, Dixon Co.; Niobrara SP, Knox Co.; and Lake Yankton SRA, just below the Gavins Point Dam, Cedar County. Grove Lake, Antelope Co. (plus nearby ponds and streams), is good and close to the must-see Ashfall Fossil Beds SHP. The various state wildlife management areas and abatement reservoirs are worth checking: Maskenthine Lake RA, Stanton Co.; Hull Lake SWMA, Boyd Co.; Stevenson Lake, 3.5 miles SW of Petersburg and private, Boone Co., being better than average. The restored Fort Atkinson SHP, Washington Co. near Ft. Calhoun, was the largest US military establishment in the 1820s, is located on the Council Bluffs where Lewis and Clark signed treaties with the local Indians, and is worth a stop if you're tired of 
chasing odonates. You can continue past the fort to Boyer Chute NWR, where some of the channels and wet areas are decent for odonates. The Northeast has a somewhat limited species diversity (70 species recorded in the 19 counties) but only Antelope (40) and Dodge (35) have half of the region's species and Nance, Merrick, and Wayne have only 22 species.

The Northeast region is the western boundary for Gomphurus vastus (Cobra Clubtail) and Enallagma traviatum (Slender Bluet), has one of two records for Dromogomphus spoliatus (Flag-tailed Spinyleg), two of the five records for Enallagma vesperum (Vesper Bluet), and two of the four records for Neurocordulia molesta (Smoky Shadowdragon).

\section{Counties}

1: Cuming, Dakota, Madison, Nance, Pierce, Platte, Thurston, Washington, Wayne 2: Antelope Co., Boyd Co., Cedar Co., Chalkrock SWMA (reservoir and outlet stream); Dodge Co., Fremont Lakes SRA (lakes between the highway and railroad), Hull Lake SWMA; Grove Lake; Boone Co., Stevenson Lake (private), 3.5 miles SW of Petersburg; Burt Co., Summit Lake SRA and adjacent ponds; Colfax Co., Centennial Park, SW side of Leigh; Dixon Co., Buckskin Hills SWMA; Knox Co., Niobrara SP; Stanton Co., Maskenthine Lake Rec. Area, 10 miles SE of Norfolk.

\section{SOUTHEAST}

Similar in character to the Northeast and, bounded on the north by the Platte River, on the east by the Missouri River, on the south by Kansas and on the west by a line about 10 miles east of US Highway 81. The bluffs along the Missouri are higher than in the Northeast and in many areas heavily wooded. This region does not extend as far west as the Northeast region so there is not as much former prairie. Although the three biggest cities in the state, Omaha $(409,000)$, Lincoln $(258,000)$ and Bellevue $(50,000)$ are located in this region, most of the area is as rural as the Northeast, with the other major cities (Beatrice, Crete, Nebraska City, Seward) having populations of 7-12 thousand. The average density of 151 per sq. mile for the 7710 sq. mile region is inflated by the big cities and is less than 60 per sq. mile when they are excluded. Pawnee Co. has the lowest density (6.3). Historically this was the most heavily collected region. Louisville SRA, Cass Co., is a historic collecting site and still excellent for odonates today. Indian Cave SP, Richardson and Nemaha Cos., and Brownville SRA, Nemaha Co., both on the Missouri River, are reliable sites for Gomphurus vastus as well as some other uncommon species. Heron Haven Nature Center, Douglas Co., and Fontenelle Forest Nature Center, Sarpy Co, stand out as odonate sites not only because they protect good habitat but because of the work of Brian Peterson at the former and the Padelfords at the latter. There are a number of clear sandy streams in the Nemaha River basin that support a richer fauna than the larger Blue River drainage to the west. The diversity, 76 species recorded in the 14 counties of the Southeast, is slightly higher than the Northeast because of more collecting and thus more of the uncommon species over the years. The individual county lists are, with the exception of Lancaster County (51), in the 21-38 species range. Lancaster County stands out because of collecting by students and faculty from the University of Nebraska over a great number of years as well as the presence of a multitude of SRAs and WMAs that cumulatively provide a great diversity of odonates, although no one site is particularly outstanding.

This region has the only state records for Ischnura barberi (Desert Forktail), five of the six records for Ischnura posita (Fragile Forktail), one of two records for Nasiaeschna pentacantha 
(Cyrano Darner), three of five records for Erpetogomphus designatus (Eastern Ringtail), one of four records for Stylurus notatus (Elusive Clubtail), only record for Macromia (River Cruiser), only record for Brachymesia herbida (Tawny Pennant), and the only two records for Sympetrum danae (Black Meadowhawk). Not surprisingly, the majority of these records are from Missouri River counties.

\section{Counties}

1: Butler, Johnson, Lancaster, Otoe, Pawnee, Seward Counties

2: Cass Co., Louisville SRA; Douglas Co., Two Rivers SRA and Heron Haven; Gage Co., Rockford Lake SRA; Nemaha Co., Brownville SRA; Richardson Co., Indian Cave SP and Verdon Lake SRA; Saline Co., Swan Creek SWMA; Sarpy Co., Fontenelle Forest; Saunders Co., Memphis SRA

\section{SANDHILLS}

The Sandhills cover one third of Nebraska, contain half of Nebraska's ranch land, and are closer to their original condition than other regions of the state. Cherry County, in the center of the Sandhills, has the largest county list (72), is the largest county in the state, is the number one cattle county in the US, and, with Garden County, has the highest density of Sandhill lakes. Most of this unique area of rolling grass-covered sand dunes can only be used for grazing and is quickly damaged by over grazing, so the ranches are huge and the cattle density very low. The Niobrara Valley is an exception with crop lands, extensive areas of low forest and a higher population density. The characteristic Sandhill lakes are abundant and often have a wide cattail border making access to open water difficult or limited to boat launch areas. These lakes usually have no outlet stream and the level varies with groundwater levels. The grasslands contain a few trees restricted to wet areas (cottonwood) or shelter belts (mainly cedar), but these trees can be important roost sites for odonates. We checked one isolated tree, some 3 miles from water, and flushed 5 species of odonates. An extensive planting at Shimmins Lake, Hooker County, contained several species not found at the adjacent lake and 10-100 times as many individuals. The 17 counties included in this region extend from the South Dakota border almost to the Platte. Arthur, McPherson and Logan Counties in the Southwest Region, and Garden and Sheridan in the Panhandle are also typical Sandhill counties.

Seven counties on the southeastern edge of the region (Garfield, Wheeler, Valley, Greely, Sherman, Howard and Custer) are transitional from the eastern areas and contain 4 of the 5 larger population centers in the region (O'Neill, Broken Bow, St. Paul, and Ord with populations of 2-4 thousand). Adding Valentine on the Niobrara River still gives a combined population for the 5 cities of only 14,000. If one wants prairie and solitude, this is the place to go. Fourteen counties in the greater Sandhill area have fewer than 2 people per square mile. Cherry County, a place of fond memories for many 1998 DSA participants, has one person per square mile. This density does not require many roads and access becomes the major problem in surveying the area. Arthur and McPherson counties, although assigned to the Southwest region, are stereotypic Sandhill counties and share the lowest density (fewer than 900 people in their combined 1580 square miles) of any Nebraska counties. Getting to an outstanding site, like Birdwood Creek (at Tin Can Camp, McPherson Co.), may require a two-hour drive on sand roads and eventually one-lane roads from overnight accommodation along the North Platte River. Most lakes are just not accessible. The highly productive Dismal River has road access at only 3 paved and 3 dirt road crossings in about 90 miles. 
Many odonatologists know Cherry County and Valentine and perhaps little else in the Sandhills or in Nebraska. If you can only visit one county, Cherry County and Valentine have to be the choice, but the Niobrara runs on east through several other counties and the Sandhills extend south through many more counties. Because of the difficulty of access many potentially productive sites have never been visited. Cherry County, despite the large number of visits by many naturalists, is still thinly covered.

The Niobrara River and its associated streams are a must. Boardman Creek, SSW of Valentine, should certainly be on your list - there are too many good lakes in Cherry County to point out individual sites. The Dismal River crossing south of Mullen (Hooker Co.) has been excellent, but access presents some problems. Ranches are usually located on a Sandhill lake and often have extensive plantings of shelter belts. These areas are excellent for huge numbers and a great variety of odonates. Cub Creek Lake, Keya Paha Co.; Keller Park SRA, Brown Co.; the Cedar River, Wheeler and Greeley Cos.; Bloody Creek, Rock and Loup Cos.; the lake at the entrance to the Nebraska National Forest, Thomas Co.; and Frye Lake SWMA, Grant Co., have all been better than average collecting sites. Huge emergences of hundreds and thousands of individuals are regular in the Sandhills with the mixed groups of several Sympetrum species (meadowhawks) being the most spectacular. Other species with large numbers include Rhionaeschna multicolor (Blue-eyed Darner), Pachydiplax longipennis (Blue Dasher), and several Lestes (spreadwings).

This region has the greatest diversity ( 87 species), thanks to Cherry County, but many of the 17 counties have only slightly higher odonate diversity than Southeast counties because of the uniformity of habitat and small number of streams. Unusual species: Lestes disjunctus (Northern Spreadwing), four of five records; Coenagrion resolutum (Taiga Bluet), only record; Enallagma ebrium (Marsh Bluet), three of five records; Boyeria vinosa (Fawn Darner), two of four records and only recent records, Stylurus notatus (Elusive Clubtail) two of four records; Epitheca spinigera (Spiny Baskettail), only record; Libellula auripennis (Golden-winged Skimmer), only record; and Sympetrum ambiguum (Blue-faced Meadowhawk), only record.

\section{Counties}

1: Garfield, Greeley, Holt, Howard, Sherman, Valley

2: Blaine Co., Millburn Diversion Dam; Brown Co., Keller Park SRA; Cherry Co., Smith Falls SP, Boardman Creek; Custer Co., Victoria Springs SRA; Grant Co., Frye Lake SWMA; Hooker Co., Shimmins Lake (private); Keya Paha Co., Cub Creek Lake; Loup and Rock Cos., Bloody Creek; Thomas Co., Nebraska National Forest, lake one mi. W of Halsey. Wheeler Co., Pibel Lake SRA.

\section{SOUTHCENTRAL}

This block of 19 counties is transitional between the wetter Southeast counties and very dry Southwest counties. Generally flat and cultivated, the counties are drier and less farmed as one gets to the western edge of the region. They extend from just north of the Platte River to the Kansas Border and from Columbus to Lexington. Both the Platte and Republican Rivers are important factors in the region, but the Big and Little Blue Rivers drain most of the area between the Platte and Republican Rivers. This area includes the Rainwater Basin that is an important migration stop-over for ducks and geese. The numerous wildlife management areas and Federal Wildlife Production Areas in the region have all, for Fred, been disappointing 
odonate sites during the study. Many obviously held more water previously and may in the future. As in the Northeast and Southeast, the land is laid out in mile squares with roads marking most of these boundaries. Most of the population is north of the Platte; Grand Island (52 thousand), Kearney (34) and Lexington (10). Hastings (25 thousand) and York (8) are south of the major northward bend of the Platte, but still close to I-80. Red Cloud at 1 thousand (home of Willa Cather, Pulitzer prize winning writer) is the biggest city on the Republican River in this region. The counties were established in the 1850-1860s, shortly after the eastern regions and some 20 years before the Sandhills and Southwest. There is a shortage of good odonates sites, particularly in the eastern half of the area, but Ft. Kearny SRA is exceptional, although river access is limited. The extensive borrow pit lakes, several aerated, provide a great variety of permanent wetland habitat. The outflow areas and seepage areas below Harlan County Reservoir are also exceptional, particularly when the flow on the Republican River is reduced. There are a series of SRAs and one rest stop along I-80 that provide additional borrow pit lakes, but nothing matching Ft. Kearny SRA.

The diversity (66 species) in this region and the 19 individual county lists (21-39) is low, matching the Northeast counties without Missouri River frontage. Unusual species are: Enallagma vesperum (Vesper Bluet), two of five records; Ischnura posita (Fragile Forktail), one of six records; Nasiaeschna pentacantha (Cyrano Darner), one of two records; Stylurus plagiatus (Russet-Tipped Clubtail), the only two records; Neurocordulia molesta (Smoky Shadowdragon), one of four records; Tramea calverti (Striped Saddlebag), one of two records.

\section{Counties}

1: Clay, Dawson, Fillmore, Franklin, Gosper, Hamilton, Merrick, Nuckolls, Polk, Thayer, York 2: Adams Co., Crystal Lake SRA; Buffalo and Kearney Co., Fort Kearny SRA; Hall Co., Mormon Island SRA; Harlan Co., Harlan County Reservoir and outflow, Jefferson Co., Alexandria Lakes SRA; Phelps Co., Sandy Channel SRA; Webster Co., Elm Creek SWMA.

\section{SOUTHWEST}

This area was not settled until the 1870s-1880s, 20-30 years later than eastern regions, and the counties are drier, less cultivated and less populated than the state as a whole. McCook is often the hottest place in the state and Perkins County is the driest county in the state. Away from irrigated croplands in the river bottoms, it is mostly open ranching county. The North and South Platte run through the northern part of the region and the Republican River through the south. The three counties on the northern edge of the area (Arthur, McPherson, and Logan) are typical Sandhill areas and used primarily for grazing. The land rises fairly quickly from the river bottoms and a rough cross section of the area north to south would be Sandhills, Platte Valley, highland grazing area, Republican Valley, more dry highland grazing land, Kansas.

The average population density is 6.4 per square mile, but if one removes the big cities of North Platte (where North and South Platte River separate), Ogallala on the South Platte and McCook on the Republican (24, 8 and 5 thousand respectively) the density drops closer to 3 per sq. mile.

Seventy-seven species have been recorded in the 13 counties with a range of 22-35 species per county (Lincoln has 61). The diversity for the region is good because of the large range of habitats covered, extensive collecting in Lincoln County and the influx of western species, but there is a shortage of dragonfly habitat in all counties but Lincoln. Birdwood Creek, McPherson 
Co.; Ambler Lake, Logan Co.; outflow from Enders Reservoir SRA, Chase Co.; outflow below Medicine Creek Reservoir SRA and Red Willow Reservoir SRA both Frontier Co.; Rock Creek SRA, Dundy Co., are much better than average but are often one of only a few decent wetland sites in a county. Lincoln, like Lancaster County, has a large number of decent odonate sites but none are outstanding.

Perkins County, as the driest county, has one stream (with no odonates) and fewer than 10 semi-permanent ponds (all small to tiny and subject to considerable fluctuation in level and pollution). Stinking Creek during a very wet year still had no habitat for odonates. Because of the limited wetlands and huge fluctuations in available habitat between wet and dry years, species may be limited to one or a few sites and subject to repeated local extinction and recolonization.

Unusual species are: Erpetogomphus designatus (Eastern Ringtail), two of five records; Dythemis fugax (Checkered Spreadwing), only record; Tramea calverti (Striped Saddlebags), one of two records.

The SW area of the region was one of the last holdouts for large herds of buffalo and in January of 1872 a buffalo hunt was organized for Grand Duke Alexis of Russia with Buffalo Bill as guide and generals George Custer and Phil Sheridan as hosts. In the 1860s and 1870s the US Army held an annual buffalo hunt for the Indians with each tribe assigned designated hunting areas. In July 1873 this resulted in the last large Indian battle when the Sioux slaughtered some 200 Pawnee who had encroached on their area.

\section{Counties}

1: Arthur, Furnas, Keith, Lincoln, Perkins, Red Willow

2: Chase Co., outlet of Enders Reservoir; Dundy Co., Rock Creek SRA and fish hatchery; Frontier Co., outflow below Medicine Creek and Red Willow Reservoirs; Hayes Co., Frenchman Creek SWMA; Hitchcock Co., Swanson Reservoir SRA above and below dam; Logan Co., Ambler Lake, west of Stapleton; McPherson Co., Schnick Lake, Diamond Bar Lake, Birdwood Creek

\section{PANHANDLE}

This region of 10 counties is distinctive. You are now in the west with buttes, canyons and badlands, the distinctive Oregon wagon trail landmarks of Chimney Rock, Courthouse Rock, Jail Rock, and Scotts Bluff along the Platte, the unique Pine Ridge country and badlands in the northwest corner. Garden and Sheridan Counties are more like Sandhill counties than western counties with Garden rivaling Cherry County for most Sandhill lakes. Kimball County proudly claims to be the ICBM capital of the world and positions one of the missiles in its city park. The highest point in the state is in Kimball County although hardly elevated above the surrounding land and almost impossible to get directions to or to find after getting directions. The high points in Sioux and Dawes counties are almost as high as in Kimball but much more obvious, being high buttes or pine covered ridges.

The whole area is dry but the three southern counties (Kimball, Cheyenne and Deuel) have only a few wetland areas. Lodgepole Creek runs through all of them before joining the Republican River west of McCook. This creek is small, shallow, spring fed in sections and dry in others but the only (?) source for stream species in these southern counties.

The (only?) good odonate habitat in Kimball Co. is Lodgepole Creek both above Oliver Reservoir SRA and from the reservoir to the town of Kimball. In Cheyenne Co. there are several 
places to access Lodgepole Creek but the most productive site was a private bass pond just off I-80 (exit 6). In Deuel Co., Chappell Lake, off Lodgepole Creek, is good as is Goldeneye SWMA, near Big Springs. Banner County is the second driest county in the state with essentially one spring-fed wildlife pond (Buffalo Creek SWMA) and some short spring-fed streams. Twenty-five of the thirty county records are from this small wildlife pond, a mile walk from the parking lot, with considerable fluctuation in level, vegetation and species from year to year. The rest of the records come from a small stream crossing on Highway 88. The North Platte runs past Scottsbluff (Scotts Bluff Co.) and Bridgeport (Morrill Co.) but is not particularly good for odonates. However, the borrow pit fishing lakes next to the Scottsbluff Zoo are, and the lakes in the Bridgeport SRA are good. North of the North Platte in Scotts Bluff Co. there are a number of lakes and tributary streams to the Platte and in Morrill Co. somewhat fewer and less productive tributary streams. South of the North Platte one of the few wetland sites is Mud Springs Pony Express Station, Morrill Co. This is a spring/wetlands in the middle of dry grasslands some 20 miles south of Bridgeport. Garden County is overloaded with lakes and contains a few streams, and although many lakes and a few streams are easily accessible, most are not. Box Butte County has lost most of its wetland due to lowering of the water table (i.e. the wet areas spotted across the county in the DeLorme Atlas are no longer there). Kilpatrick Lake west of Alliance and the Niobrara River on the border with Dawes County are almost the only productive sites in the county. In 2014 Kilpatrick Lake was totally dry and had been for many months. The northern counties (Sioux, Dawes and Sheridan), despite most of the area being dry grasslands or badlands (Sioux Co.), have permanent rivers (White and Niobrara Rivers) and a number of good trout streams. Good ponds are found in the Fort Robinson SP and one in the Gilbert-Baker SWMA (a small pond on the other side of road from camping area with Rhionaeschna californica in early spring ). South of Rushville in Sheridan Co. there is a series of Sandhill lakes with Smith Lake SWMA and outlet (Pine Creek) being the most accessible and probably the best. Dawes County has a variety of ponds and streams plus Whitney Lake..

The counties in this region were established in the 1880s, 30 years after the eastern counties. Scottsbluff, on the North Platte, with 15,000 people, is the largest city in the region and Alliance $(8,000$ and site of Carhenge), Sidney $(7,000$ and first Cabela's store), and Chadron $(6,000)$ are the only other major population centers.

Seventy-five species have been recorded in the 11 counties with a range of 30-60 species and an average of 42 per county. The following species are found almost exclusively in Panhandle counties. The first number following the species is the number of Panhandle counties where the species has been recorded, the second is the number of county records outside the Panhandle: Enallagma annexum (Northern Bluet) (9/3), Enallagma boreale (Boreal Bluet) (6/0), Enallagma praevarum (Arroyo Bluet) (8/2), Ischnura damula (Plains Forktail) (11/5), Rhionaeschna californica (California Darner) (2/0), Somatochlora ensigera (Plains Emerald) (2/1), Libellula forensis (Eight-spotted Skimmer) (4/0), Plathemis subornata (Desert Whitetail) (5/2), Sympetrum madidum (Red-veined Meadowhawk) (2/0), and Sympetrum pallipes (Striped Meadowhawk) (8/1).

Like the lowa/Nebraska border, the Nebraska/Wyoming border marks a transition in habitat, but a much sharper one. A number of species found in the Panhandle of Nebraska disappear or become rare only a short way into Wyoming. 


\section{APPENDIX B - SPECIES ERRONEOUSLY REPORTED FROM NEBRASKA}

\section{Hetaerina titia (Smoky Rubyspot)}

Pub: Keech, 1934

We have found no specimens or valid reports of this species in Nebraska; however, H. titia is found just across the Missouri River in 5 of 26 western lowa counties, although it is absent from all but two Kansas counties on the eastern border of that state. This late season species should turn up in August and September in streams on the eastern border of Nebraska. Keech (1934) lists 2 males and a female from Louisville, Cass County, in 1913 and 1914 . The specimens in UNSM corresponding to these dates and locality are H. americana. Westfall \& May, 1996, and Johnsgard, 2001, perpetuate this error.

\section{Ischnura cervula (Pacific Forktail)}

Pub: Donnelly, 2004c

This is a western species with only a few records east of the Colorado foothills. The Dot Map record, OC\# 203611, was based on a single Ischnura caught and sketched at Oliver Reservoir, Kimball County, Aug. 30, 2001. The observer was not familiar with the difference between this species and the abundant $I$. damula, found at the site, and evidently used the presence of a "fork" on 10th segment rather than the size of the "fork" to identify it.

\section{Argia bipunctulata (Seepage Dancer)}

Pub: Clopton, et. al. 1993

Argia bipunctulata was designated as the type host for a new parasite (page 536) and this parasite ". . .was collected consistently from Argia bipunctulata ..." (page 533). Enallagma civile is also listed as a host and the parasite was found in ". . . naiads and adults. .." of both species (p. 536). The work was done between July and September 1992 with 69 of the 119 damselflies inspected being infested. The type locality, given as Bowling Lake ("Section 2, Township 10 North, Range 6 East"), is incorrect. The lake is actually in sec 6 at $4052.00 \mathrm{~N}, 96$ $46.95 \mathrm{~W}$, but it is not clear if all the damselflies were collected there. There is no indication any of the damselflies were preserved as voucher specimens. Enquires by Don and Janis Paseka, at the University of Nebraska Museum and in the Parasitology Department, for such specimens drew a blank. This record is several hundred miles north and west of the known range for $A$. bipunctulata and visits to Bowling Lake, a typical urban park pond, have not turned up additional records of the species. It seems to be an obvious misidentification judging from the range, habitat and the taxonomic inexperience of the collectors.

\section{Rhionaeschna mutata (Spadderdock Darner)}

Pub: Moody, 1967

In his thesis (p.17) Moody reports a specimen collected 15 miles south of Hay Springs, Sheridan County, on Aug. 17, 1966. This specimen, at Chadron State College, was examined in 2014 and determined to be a male Aeshna palmata (Paddle-tailed Darner).

\section{Gomphurus fraternus (Midland Clubtail)}

Pub: OC\#: 356687

A male in the University of Texas (UTIC 2713) is listed (OC \# 356687) as collected by Sid Dunkle at Minnechaduza Creek, Valentine, Cherry Co., on July 20, 1998. Sid Dunkle collected extensively at the Minnechaduza Creek location on July 20 and supplied his species list to Roy 
Beckemeyer. Roy's 1998b report on the meeting does not contain G. fraternus nor could John Abbott locate this specimen at the University of Texas, we suspect a misidentification or typo. Phanogomphus lividus (Ashy Clubtail)

Pub: Keech, 1934

Keech lists a female from Warbonnet Canyon, Sioux County, without a date but probably in the 1910-15 range. This specimen, missing terminal segments, is in the pinned reference collection at UNSM, and was re-identified as Phanogomphus graslinellus by Thomas Donnelly (Donnelly, 2000a). Needham \& Westfall, 1955, and Johnsgard, 2001, contain this error. $P$. lividus is an eastern species and this record would have extended the range some miles west. Stylurus olivaceus (Olive Clubtail)

Pub: Muttkowski, 1910

A far western species listed from Nebraska based on a list of Nebraska odonates supplied to Muttkowski by Lawrence Bruner, Entomology professor at the University of Nebraska. Needham \& Haywood, 1929, as well as Keech, 1934, continued this error. This was possibly a misidentification of the Stylurus amnicola specimen in University of Nebraska collection.

\section{Epitheca costalis (Slender Baskettail)}

Pub: Beckemeyer \& Hummel, 1998b

The two records listed by Beckemeyer and Hummel (1999a) were re-identified by Thomas Donnelly in 2012-2013. The specimen from Holt County (OC\# 187213) was collected 3 miles southeast of O'Neill by Steve and Mary Jane Krotzer on July 16, 1998 (Krotzer collection). This was determined to be E. cynosura. The specimen from Lincoln County (OC\# 187214) was collected near North Platte by Sid Dunkle on July 15, 1998. The specimen (IORI) was originally recorded by Sid as E. petechialis/E. costalis, and later determined to be $E$. petechialis by Thomas Donnelly. Donnelly, 2005b (Dot Maps) and Needham, et al., 2000, list E. costalis for Nebraska.

\section{Brachymesia gravida (Four-spotted Pennant)}

Pub: Keech, 1934

Keech lists a male specimen collected by E.G. Anderson, Aug. 2, 1914, at Louisville, Cass County. This specimen was re-identified by Thomas Donnelly (Donnelly, 2000a) as Brachymesia herbida (OC\# 396382). Nebraska is well north of the normal range for both species. Needham \& Westfall, 1955, and Johnsgard, 2001, contain this error.

Leucorrhinia hudsonica (Hudsonian Whiteface)

Pub: Keech, 1934, Beckemeyer, 1998b

This northern species occurs close to Nebraska in the Black Hills and Colorado. Keech (1934) lists a female from Omaha, Douglas County, without date but possibly 1913-1915. This specimen (in the pinned reference collection of UNSM) is L. intacta. Needham \& Westfall, 1955, and Johnsgard, 2001, contain this error. The teneral female, OC\# 218730, collected in Brown County on the Niobrara River near Norden by R.D. Cuyler July 18, 1998, was reported by Beckemeyer (1998b) as a new state record. Thomas Donnelly re-identified this in 2013 as $L$. intacta (IORI \# 000057143), but Donnelly, 2005b, and Needham, et al., 2000, contain this error. Libellula flavida (Yellow-sided Skimmer)

Pub: Pruess, 1967

This name first appears in the Pruess list based on a male collected at Fort Crowe Ranch south of Valentine, Cherry Co., on Sept. 30, 1960, by W. T. Atyeo (pinned collection UNSM). It was re-identified (Donnelly 2000a) as L. auripennis. Needham, et al., 2000, contains this error. 


\section{APPENDIX C - LESTES AUSTRALIS/DISJUNCTUS}

Lestes australis and Lestes disjunctus (Southern \& Northern Spreadwing) have been regarded as conspecific, subspecies or full species at different times and have always been hard to separate (Donnelly, 2000b). This difficulty has resulted in erroneous distribution records in many states besides Nebraska. Keech (1934) does not list either species, although there are 3 Lancaster County specimens of australis, from 1908 and 1912, in the UNSM collection. Pruess (1967) and Roy Beckemeyer (1998A \& B) list only Lestes disjunctus australis for the state. Nick Donnelly's (2004c) dot maps have no L. disjunctus records for the state but undetermined records of either L. australis or L. disjunctus from Sioux, Cherry, Douglas, Lancaster, Gage and Red Willow. The dot map for L. australis shows three dots with Cherry and Lincoln obvious, but the third dot is evidently a typo that doesn't show up on any subsequent listings.

The dot map files were transferred to the Odonata Central system in 2005. The dots representing uncertain identifications were all treated as $L$. disjunctus and thus there are listings for Sioux, Cherry, and (incorrectly) Douglas, Lancaster, Gage and Red Willow. Roy Beckemeyer (1998b) reported L. australis from Brown County but this does not appear on the dot maps.

Thomas Donnelly has volunteered a lot of time and been incredibly patient identifying specimens collected in this study and re-identifying specimens from the DSA meeting. This indicates $L$. australis is almost state-wide with $L$. disjunctus restricted to the northern counties. There are confirmed $L$. disjunctus specimens only from Cherry, Brown, Thomas and Holt counties. We assume the Sioux County record is correct. We have collected 60 specimens of $L$. australis elsewhere in the state but only found one new record for disjunctus (Thomas County). Although we can't tie specific specimens to the dot map records, all the dot map records are credited to specimens in the University of Nebraska State Museum and we have found only $L$. australis specimens in that collection - from (Douglas, Lancaster, and Red Willow Counties). The Gage County record (no specimen found) is assumed to be $L$. australis.

We have found no locality where $L$. australis and $L$. disjunctus occur together. This is strange, as both species are found in Keya Paha and Cherry Counties, and three other northern counties have $L$. australis and three have L. disjunctus. In Sheridan County, at Smith Lake SRA, L. australis was abundant on June 24, 2010 (Matt Brust) . 


\section{APPENDIX D - DOT MAP RECORDS WITHOUT DOCUMENTATION}

We have not found specimens or photographs for the 42 dot map records listed below by county (ref. Donnelly 2004a, b, c). If you can document any of these records with either older records or recent collecting, please make an entry of the county record in Odonata Central.

Lestes forcipatus from Lancaster County is possibly in error as it is attributed to the UNSM collection and no specimen from Lancaster County was found there. The Rhionaeschna multicolor is on the extreme SE edge of range and also attributed to the UNSM collection (no specimen found). The Somatochlora ensigera (Sioux Co.) is a rare species everywhere and knowing an exact locality would be important. There is little reason to doubt the other records but information on locality is always useful.

The comments following the species are based on Roy Beckemeyer (1999a, b) lists.

DSA98 (27 records) indicates Roy had a report of this from some participants at the 1998 DSA meeting in Cherry County. The original submissions were lost, and not all participants were located or responded to a new request for records.

UNSM (University of Nebraska State Museum - 13 records) indicates Roy found a specimen in that collection. We have either found that the specimen was misidentified or were unable to find a specimen from that county.

HKB99 (2 records) is presumably someone with initials HKB who collected in 1999.

Antelope County: Enallagma annexum - UNSM

Perithemis tenera - DSA98

Box Butte County: Calopteryx maculata - DSA98

Lestes congener - DSA98

Brown County: Lestes forcipatus - DSA98

Enallagma exsulans - DSA98

Pantala hymenaea - DSA98

Buffalo County: Aeshna constricta - UNSM

Chase County: Libellula quadrimaculata - UNSM

Cherry County: Progomphus obscurus - UNSM

Epitheca princeps - DSA98

Cheyenne County: Argia fumipennis - UNSM

Dawes County: Calopteryx aequabilis - DSA98

Lestes forcipatus - DSA98

Pantala flavescens - DSA98

Dodge County: Amphiagrion intermediate-DSA98

Pantala hymenaea-DSA98

Dundy County: Enallagma carunculatum - DSA98

Sympetrum obtrusum - DSA98

Grant County: Enallagma clausum - DSA98

Leucorrhinia intacta - DSA98

Sympetrum rubicundulum - UNSM

Hamilton County: Sympetrum semicinctum - UNSM

Holt County: Argia sedula - DSA98 


\section{Appendix D - continued}

Hooker County: Sympetrum corruptum - DSA98

Sympetrum internum - DSA98

Sympetrum semicinctum - DSA98

Lancaster County: Lestes forcipatus - UNSM - probably misidentification

Stylurus intricatus - UNSM

Pantala hymenaea - UNSM

Lincoln County: Ischnura hastata - DSA98

Logan County: Argia alberta - UNSM

Madison County: Pachydiplax longipennis - DSA98

Nemaha County: Rhionaeschna multicolor - UNSM

Otoe County: Pantala hymenaea - DSA98

Red Willow County: Enallagma carunculatum - DSA98

Perithemis tenera - DSA98

Seward County: Sympetrum internum - UNSM

Sioux County: Lestes disjunctus - "HKB99"

Aeshna constricta - DSA98

Somatochlora ensigera - "HKB99"

Thomas County: Pantala flavescens - DSA98 


\section{APPENDIX E BIOGENGRAPHICAL ASSIGNMENT OF SPECIES}

\begin{tabular}{|c|c|c|c|c|}
\hline $\mathrm{BIO}$ & TAXON & ENGLISH & $\begin{array}{r}\text { CR } \\
2017\end{array}$ & $\begin{array}{r}\text { CR } \\
2004\end{array}$ \\
\hline $\mathrm{TN}$ & Calopteryx aequabilis & River Jewelwing & 16 & 7 \\
\hline $\mathrm{E}$ & Calopteryx maculata & Ebony Jewelwing & 80 & 17 \\
\hline $\mathrm{TS}$ & Hetaerina americana & American Rubyspot & 89 & 27 \\
\hline $\mathrm{TS}$ & Archilestes grandis & Great Spreadwing & 14 & 4 \\
\hline $\mathrm{E}$ & Lestes australis & Southern Spreadwing & 38 & 2 \\
\hline $\mathrm{TN}$ & Lestes congener & Spotted Spreadwing & 17 & 8 \\
\hline TN & Lestes disjunctus & Northern spreadwing & 5 & 2 \\
\hline TN & Lestes dryas & Emerald Spreadwing & 11 & 3 \\
\hline $\mathrm{TN}$ & Lestes forcipatus & Sweetflag Spreadwing & 18 & 4 \\
\hline $\mathrm{E}$ & Lestes rectangularis & Slender Spreadwing & 49 & 9 \\
\hline $\mathrm{TN}$ & Lestes unguiculatus & Lyre-tipped Spreadwing & 78 & 27 \\
\hline $\mathrm{TN}$ & Amphiagrion intermediate & Red Damsel & 54 & 18 \\
\hline $\mathrm{W}$ & Argia alberta & Paiute Dancer & 39 & 5 \\
\hline $\mathrm{E}$ & Argia apicalis & Blue-fronted Dancer & 80 & 17 \\
\hline $\mathrm{W}$ & Argia emma & Emma's Dancer & 12 & 8 \\
\hline $\mathrm{E}$ & Argia fumipennis & Variable Dancer & 42 & 11 \\
\hline $\mathrm{E}$ & Argia moesta & Powdered Dancer & 34 & 4 \\
\hline $\mathrm{W}$ & Argia nahuana & Aztec Dancer & 16 & 0 \\
\hline $\mathrm{C}$ & Argia plana & Springwater Dancer & 29 & 3 \\
\hline $\mathrm{TS}$ & Argia sedula & Blue-ringed Dancer & 20 & 6 \\
\hline $\mathrm{E}$ & Argia tibialis & Blue-tipped Dancer & 24 & 3 \\
\hline $\mathrm{W}$ & Argia vivida & Vivid Dancer & 14 & 5 \\
\hline TN & Coenagrion resolutum & Taiga Bluet & 1 & 1 \\
\hline $\mathrm{W}$ & Enallagma anna & River Bluet & 36 & 9 \\
\hline $\mathrm{TN}$ & Enallagma annexum & Northern Bluet & 12 & 2 \\
\hline $\mathrm{E}$ & Enallagma antennatum & Rainbow Bluet & 54 & 7 \\
\hline $\mathrm{E}$ & Enallagma aspersum & Azure Bluet & 13 & 1 \\
\hline $\mathrm{E}$ & Enallagma basidens & Double-striped Bluet & 37 & 4 \\
\hline TN & Enallagma boreale & Boreal Bluet & 6 & 3 \\
\hline TN & Enallagma carunculatum & Tule Bluet & 47 & 21 \\
\hline $\mathrm{TS}$ & Enallagma civile & Familiar Bluet & 93 & 27 \\
\hline $\mathrm{W}$ & Enallagma clausum & Alkali Bluet & 8 & 5 \\
\hline TN & Enallagma ebrium & Marsh Bluet & 5 & 2 \\
\hline $\mathrm{E}$ & Enallagma exsulans & Stream Bluet & 25 & 3 \\
\hline $\mathrm{E}$ & Enallagma geminatum & Skimming Bluet & 24 & 2 \\
\hline $\mathrm{TN}$ & Enallagma hageni & Hagen's Bluet & 37 & 13 \\
\hline $\mathrm{W}$ & Enallagma praevarum & Arroyo Bluet & 10 & 5 \\
\hline $\mathrm{E}$ & Enallagma signatum & Orange Bluet & 28 & 2 \\
\hline $\mathrm{E}$ & Enallagma traviatum & Slender Bluet & 3 & 0 \\
\hline $\mathrm{E}$ & Enallagma vesperum & Vesper Bluet & 5 & 0 \\
\hline SW & Ischnura barberi & Desert Forktail & 1 & 1 \\
\hline
\end{tabular}




\begin{tabular}{|c|c|c|c|c|}
\hline & Appendix E & continued & & \\
\hline Bio & Taxon & English & 2017 & 2004 \\
\hline $\mathrm{C}$ & Ischnura damula & Plains Forktail & 16 & 6 \\
\hline $\mathrm{E}$ & Ischnura hastata & Citrine Forktail & 19 & 2 \\
\hline $\mathrm{W}$ & Ischnura perparva & Western Forktail & 20 & 10 \\
\hline E & Ischnura posita & Fragile Forktail & 6 & 1 \\
\hline $\mathrm{E}$ & Ischnura verticalis & Eastern Forktail & 93 & 34 \\
\hline TN & Nehalennia irene & Sedge Sprite & 7 & 3 \\
\hline TN & Aeshna canadensis & Canada Darner & 8 & 6 \\
\hline $\mathrm{TN}$ & Aeshna constricta & Lance-tipped Darner & 24 & 6 \\
\hline TN & Aeshna interrupta & Variable Darner & 11 & 6 \\
\hline $\mathrm{W}$ & Aeshna palmata & Paddle-tailed Darner & 5 & 3 \\
\hline TN & Aeshna umbrosa & Shadow Darner & 11 & 5 \\
\hline TN & Anax junius & Common Green Darner & 88 & 16 \\
\hline E & Boyeria vinosa & Fawn Darner & 4 & 2 \\
\hline E & Nasiaeschna pentacantha & Cyrano Darner & 2 & 0 \\
\hline $\mathrm{W}$ & Rhionaeschna californica & California Darner & 2 & 1 \\
\hline $\mathrm{W}$ & Rhionaeschna multicolor & Blue-eyed Darner & 44 & 11 \\
\hline $\mathrm{C}$ & Arigomphus cornutus & Horned Clubtail & 11 & 2 \\
\hline $\mathrm{C}$ & Arigomphus submedianus & Jade Clubtail & 10 & 2 \\
\hline $\mathrm{E}$ & Dromogomphus spoliatus & Flag-tailed Spinyleg & 2 & 0 \\
\hline $\mathrm{E}$ & Erpetogomphus designatus & Eastern Ringtail & 5 & 0 \\
\hline $\mathrm{C}$ & Gomphurus externus & Plains Clubtail & 37 & 8 \\
\hline $\mathrm{E}$ & Gomphurus vastus & Cobra Clubtail & 7 & 2 \\
\hline $\mathrm{W}$ & Ophiogomphus severus & Pale Snaketail & 19 & 7 \\
\hline $\mathrm{C}$ & Phanogomphus graslinellus & Pronghorn Clubtail & 7 & 3 \\
\hline $\mathrm{C}$ & Phanogomphus militaris & Sulphur-tipped Clubtail & 20 & 1 \\
\hline $\mathrm{E}$ & Progomphus obscurus & Common Sanddragon & 24 & 4 \\
\hline $\mathrm{C}$ & Stylurus amnicola & Riverine Clubtail & 13 & 6 \\
\hline $\mathrm{C}$ & Stylurus intricatus & Brimstone Clubtail & 17 & 8 \\
\hline $\mathrm{E}$ & Stylurus notatus & Elusive Clubtail & 4 & 1 \\
\hline $\mathrm{E}$ & Stylurus plagiatus & Russet-tipped Clubtail & 2 & 0 \\
\hline $\mathrm{E}$ & Macromia sp & River Cruiser & 1 & 0 \\
\hline $\mathrm{E}$ & Epitheca cynosura & Common Baskettail & 47 & 7 \\
\hline $\mathrm{C}$ & Epitheca petechialis & Dot-winged Baskettail & 16 & 1 \\
\hline E & Epitheca princeps & Prince Baskettail & 37 & 7 \\
\hline TN & Epitheca spinigera & Spiny Baskettail & 1 & 0 \\
\hline $\mathrm{E}$ & Neurocordulia molesta & Smoky Shadowdragon & 4 & 1 \\
\hline $\mathrm{C}$ & Somatochlora ensigera & Plains Emerald & 3 & 2 \\
\hline TRO & Brachymesia herbida & Tawny Pennant & 1 & 1 \\
\hline E & Celithemis elisa & Calico Pennant & 28 & 1 \\
\hline $\mathrm{E}$ & Celithemis eponina & Halloween Pennant & 65 & 6 \\
\hline SW & Dythemis fugax & Checkered Setwing & 1 & 0 \\
\hline E & Erythemis simplicicollis & Eastern Pondhawk & 92 & 26 \\
\hline TN & Leucorrhinia intacta & Dot-tailed Whiteface & 23 & 11 \\
\hline
\end{tabular}




\begin{tabular}{|l|l|l|r|r|}
\hline & \multicolumn{1}{|c|}{ Appendix E } & continued & & \\
\hline Bio & Taxon & English & $\mathbf{2 0 1 7}$ & $\mathbf{2 0 0 4}$ \\
\hline E & Libellula auripennis & Golden-winged Skimmer & 1 & 1 \\
\hline W & Libellula forensis & Eight-spotted Skimmer & 4 & 1 \\
\hline TS & Libellula luctuosa & Widow Skimmer & 93 & 33 \\
\hline TS & Libellula pulchella & Twelve-spotted Skimmer & 93 & 40 \\
\hline TN & Libellula quadrimaculata & Four-spotted Skimmer & 10 & 7 \\
\hline TS & Pachydiplax longipennis & Blue Dasher & 91 & 19 \\
\hline TN & Pantala flavescens & Wandering Glider & 35 & 6 \\
\hline TS & Pantala hymenaea & Spot-winged Glider & 20 & 8 \\
\hline E & Perithemis tenera & Eastern Amberwing & 73 & 16 \\
\hline TS & Plathemis lydia & Common Whitetail & 93 & 31 \\
\hline W & Plathemis subornata & Desert Whitetail & 7 & 2 \\
\hline E & Sympetrum ambiguum & Blue-faced Meadowhawk & 1 & 1 \\
\hline W & Sympetrum corruptum & Variegated Meadowhawk & 82 & 25 \\
\hline TN & Sympetrum costiferum & Saffron-winged Meadowhawk & 30 & 12 \\
\hline TN & Sympetrum danae & Black Meadowhawk & 2 & 0 \\
\hline TN & Sympetrum internum & Cherry-faced Meadowhawk & 44 & 14 \\
\hline W & Sympetrum madidum & Red-veined Meadowhawk & 2 & 1 \\
\hline TN & Sympetrum obtrusum & White-faced Meadowhawk & 69 & 25 \\
\hline W & Sympetrum pallipes & Striped Meadowhawk & 9 & 4 \\
\hline E & Sympetrum rubicundulum & Ruby Meadowhawk & 50 & 19 \\
\hline TN & Sympetrum semicinctum & Band-winged Meadowhawk & 58 & 22 \\
\hline TS & Sympetrum vicinum & Autumn Meadowhawk & 24 & 11 \\
\hline TRO & Tramea calverti & Striped Saddlebags & 2 & 0 \\
\hline TS & Tramea lacerata & Black Saddlebags & 91 & 12 \\
\hline TS & Tramea onusta & Red Saddlebags & 38 & 4 \\
\hline & & & & \\
\hline
\end{tabular}

$\mathrm{E}=$ Eastern Species, W= Western, $\mathrm{C}=$ Central (Great Plains), $\mathrm{TN}=$ Transcontinental Northern, $\mathrm{TS}=$ Transcontinental Southern, $\mathrm{SW}=$ Southwest, $\mathrm{TRO}=$ Tropical. 


\section{Appendix F - COUNTY RECORDS BY COUNTY AND BIOGEO ORIGIN SPECIES BY GAME AND PARKS REGIONS}

\begin{tabular}{|c|c|c|c|c|c|c|c|}
\hline & $\mathbf{C}$ & $\mathbf{E}$ & $\mathbf{T N}$ & TS & $\mathbf{W}$ & 2017 & 2004 \\
\hline NEBRASKA SP. & 11 & 37 & 28 & 12 & 17 & 109 & 97 \\
\hline NORTHEAST SP. & 6 & 30 & 18 & 12 & 6 & 72 & 38 \\
\hline Antelope & 3 & 14 & 11 & 9 & 3 & 40 & 21 \\
\hline Boone & 2 & 13 & 5 & 9 & $\mathbf{1}$ & 30 & $\mathbf{0}$ \\
\hline Boyd & 2 & 15 & 5 & 7 & 3 & 32 & $\mathbf{0}$ \\
\hline Burt & 1 & 9 & 5 & 8 & 2 & 25 & $\mathbf{0}$ \\
\hline Cedar & 2 & 12 & 5 & 7 & 4 & 30 & 1 \\
\hline Colfax & 1 & 11 & 3 & 8 & 1 & 24 & 5 \\
\hline Cuming & 3 & 11 & 4 & 7 & 1 & 26 & 6 \\
\hline Dakota & 2 & 11 & 7 & 7 & 3 & 30 & 9 \\
\hline Dixon & 2 & 9 & 9 & 7 & 2 & 29 & 10 \\
\hline Dodge & 3 & 16 & 8 & 10 & 1 & 38 & 17 \\
\hline Knox & 3 & 12 & 8 & 7 & 2 & 32 & 2 \\
\hline Madison & 1 & 13 & 7 & 8 & 1 & 30 & 10 \\
\hline Nance & $\mathbf{0}$ & 11 & 3 & 7 & 1 & 22 & 3 \\
\hline Pierce & 2 & 11 & 5 & 9 & 2 & 29 & $\mathbf{0}$ \\
\hline Platte & 2 & 12 & 6 & 10 & 1 & 31 & 9 \\
\hline Stanton & $\mathbf{0}$ & 11 & 7 & 8 & 3 & 29 & $\mathbf{0}$ \\
\hline Thurston & 1 & 6 & 7 & 8 & 3 & 25 & $\mathbf{0}$ \\
\hline Washington & 3 & 9 & 7 & 8 & 1 & 28 & 4 \\
\hline Wayne & 1 & 6 & 5 & 7 & 3 & 22 & $\mathbf{0}$ \\
\hline Reg. Co. Rec. & 34 & 212 & 117 & 151 & 38 & 552 & 97 \\
\hline PANHANDLE SP. & 8 & 16 & 23 & 10 & 17 & 74 & 62 \\
\hline Banner & 1 & 4 & 9 & 7 & 9 & 30 & $\mathbf{0}$ \\
\hline Box Butte & 2 & 8 & 14 & 7 & 8 & 39 & 12 \\
\hline Cheyenne & 3 & 8 & 7 & 7 & 8 & 33 & 12 \\
\hline Dawes & 3 & 13 & 20 & 9 & 15 & 60 & 43 \\
\hline Deuel & 3 & 8 & 6 & 8 & 7 & 32 & $\mathbf{0}$ \\
\hline Garden & 2 & 8 & 14 & 7 & 9 & 40 & 5 \\
\hline Kimball & 2 & 7 & 12 & 5 & 8 & 34 & 7 \\
\hline Morrill & 3 & 7 & 12 & 8 & $\mathbf{1 0}$ & 40 & $\mathbf{0}$ \\
\hline Scotts Bluff & 4 & $\mathbf{1 0}$ & 15 & 7 & 12 & 48 & 23 \\
\hline Sheridan & 2 & 8 & 18 & 7 & 10 & 45 & 23 \\
\hline Sioux & 4 & 12 & 19 & 9 & 15 & 59 & 42 \\
\hline Reg. Co. Rec. & 29 & 93 & 146 & 81 & 111 & 460 & 167 \\
\hline
\end{tabular}


APPENDIX F - continued

\begin{tabular}{|c|c|c|c|c|c|c|c|}
\hline & C & $\mathbf{E}$ & $\mathbf{T N}$ & TS & W & 2017 & 2004 \\
\hline SANDHILL SP & 10 & 27 & 26 & 12 & 12 & 87 & 72 \\
\hline Blaine & 1 & 10 & 13 & 9 & 5 & 38 & 4 \\
\hline Brown & 5 & 16 & 18 & 9 & 7 & 55 & 44 \\
\hline Cherry & 5 & 21 & 25 & 10 & 11 & 72 & 66 \\
\hline Custer & 3 & 16 & 12 & 11 & 7 & 49 & 18 \\
\hline Garfield & $\mathbf{0}$ & 10 & 9 & 7 & 1 & 27 & $\mathbf{0}$ \\
\hline Grant & 3 & 9 & 13 & 9 & 4 & 38 & 17 \\
\hline Greeley & $\mathbf{0}$ & 8 & 5 & 9 & 3 & 25 & $\mathbf{0}$ \\
\hline Holt & 1 & 16 & 12 & 8 & 4 & 41 & 23 \\
\hline Hooker & 1 & 9 & 10 & 7 & 5 & 32 & 9 \\
\hline Howard & $\mathbf{0}$ & 11 & 5 & 7 & 2 & 25 & 1 \\
\hline Keya Paha & 4 & 11 & 14 & 9 & 5 & 43 & 21 \\
\hline Loup & 1 & 8 & 11 & 9 & 2 & 31 & $\mathbf{0}$ \\
\hline Rock & 2 & 11 & 10 & 9 & 4 & 36 & 5 \\
\hline Sherman & $\mathbf{1}$ & 11 & 4 & 7 & 2 & 25 & $\mathbf{0}$ \\
\hline Thomas & 3 & 12 & 15 & 9 & 5 & 44 & 26 \\
\hline Valley & $\mathbf{0}$ & 10 & 7 & 8 & 2 & 27 & $\mathbf{0}$ \\
\hline Wheeler & 1 & 11 & 8 & 8 & 1 & 29 & $\mathbf{0}$ \\
\hline Reg. Co. Rec & 31 & 200 & 191 & 145 & 70 & 637 & 234 \\
\hline CENTRAL SP. & 5 & 28 & 14 & 12 & 7 & 66 & 33 \\
\hline Adams & $\mathbf{0}$ & 12 & 4 & 10 & 1 & 27 & $\mathbf{0}$ \\
\hline Buffalo & 3 & 17 & 7 & 10 & 2 & 39 & 17 \\
\hline Clay & $\mathbf{0}$ & 12 & 4 & 8 & 2 & 26 & $\mathbf{0}$ \\
\hline Dawson & 1 & 11 & 6 & 8 & 2 & 28 & 4 \\
\hline Fillmore & $\mathbf{0}$ & 11 & 3 & 7 & $\mathbf{1}$ & 22 & 2 \\
\hline Franklin & 2 & 10 & 5 & 9 & 5 & 31 & 4 \\
\hline Gosper & 1 & 11 & 2 & 8 & 1 & 23 & $\mathbf{0}$ \\
\hline Hall & 2 & 16 & 5 & 9 & 1 & 33 & 14 \\
\hline Hamilton & $\mathbf{0}$ & 11 & 7 & 9 & 2 & 29 & 5 \\
\hline Harlan & 2 & 10 & 7 & 7 & 4 & 30 & $\mathbf{0}$ \\
\hline Jefferson & 4 & 17 & 3 & 8 & $\mathbf{0}$ & 32 & 6 \\
\hline Kearney & 1 & 17 & 4 & 8 & 1 & 31 & $\mathbf{0}$ \\
\hline Merrick & 1 & 11 & 3 & 7 & 1 & 23 & 7 \\
\hline Nuckolls & 1 & 11 & 1 & 7 & 2 & 22 & $\mathbf{0}$ \\
\hline Phelps & $\mathbf{0}$ & 13 & 5 & 8 & 2 & $29 c$ & $\mathbf{0}$ \\
\hline Polk & $\mathbf{0}$ & 10 & 3 & 6 & 2 & 21 & 6 \\
\hline Thayer & 2 & 14 & 1 & 7 & 1 & 25 & $\mathbf{0}$ \\
\hline Webster & $\mathbf{0}$ & 13 & 6 & 8 & 3 & 30 & $\mathbf{0}$ \\
\hline York & $\mathbf{0}$ & 11 & 3 & 6 & 1 & 21 & $\mathbf{0}$ \\
\hline Reg. Co. Rec. & 20 & 238 & 79 & 150 & 34 & 522 & 65 \\
\hline
\end{tabular}


APPENDIX $\mathbf{F}$ - continued

$\begin{array}{lllllll}\text { C } & \text { E } & \text { TN } & \text { TS } & \text { W } & 2017 & 2004\end{array}$

\begin{tabular}{|l|r|r|r|r|r|r|r|}
\hline SOUTHEAST SP & $\mathbf{7}$ & $\mathbf{3 3}$ & $\mathbf{1 9}$ & $\mathbf{1 2}$ & $\mathbf{5}$ & $\mathbf{7 8}$ & $\mathbf{5 2}$ \\
\hline Butler & $\mathbf{0}$ & $\mathbf{1 6}$ & $\mathbf{4}$ & $\mathbf{7}$ & $\mathbf{2}$ & $\mathbf{2 9}$ & $\mathbf{8}$ \\
\hline CasS & $\mathbf{4}$ & $\mathbf{1 6}$ & $\mathbf{1}$ & $\mathbf{9}$ & $\mathbf{1}$ & $\mathbf{3 2 c}$ & $\mathbf{2 0}$ \\
\hline Douglas & $\mathbf{0}$ & $\mathbf{1 9}$ & $\mathbf{1 6}$ & $\mathbf{1 1}$ & $\mathbf{2}$ & $\mathbf{4 8}$ & $\mathbf{2 1}$ \\
\hline Gage & $\mathbf{3}$ & $\mathbf{1 6}$ & $\mathbf{7}$ & $\mathbf{9}$ & $\mathbf{1}$ & $\mathbf{3 6}$ & $\mathbf{6}$ \\
\hline Johnson & $\mathbf{2}$ & $\mathbf{1 0}$ & $\mathbf{2}$ & $\mathbf{8}$ & $\mathbf{2}$ & $\mathbf{2 4}$ & $\mathbf{0}$ \\
\hline Lancaster & $\mathbf{5}$ & $\mathbf{1 6}$ & $\mathbf{1 4}$ & $\mathbf{1 1}$ & $\mathbf{4}$ & $\mathbf{5 1 d}$ & $\mathbf{3 5}$ \\
\hline Nemaha & $\mathbf{3}$ & $\mathbf{1 7}$ & $\mathbf{4}$ & $\mathbf{9}$ & $\mathbf{1}$ & $\mathbf{3 4}$ & $\mathbf{1}$ \\
\hline Otoe & $\mathbf{3}$ & $\mathbf{1 6}$ & $\mathbf{3}$ & $\mathbf{9}$ & $\mathbf{0}$ & $\mathbf{3 1}$ & $\mathbf{1 9}$ \\
\hline Pawnee & $\mathbf{5}$ & $\mathbf{1 6}$ & $\mathbf{1}$ & $\mathbf{9}$ & $\mathbf{1}$ & $\mathbf{3 2}$ & $\mathbf{0}$ \\
\hline Richardson & $\mathbf{4}$ & $\mathbf{1 8}$ & $\mathbf{3}$ & $\mathbf{9}$ & $\mathbf{1}$ & $\mathbf{3 5}$ & $\mathbf{1}$ \\
\hline Saline & $\mathbf{1}$ & $\mathbf{1 5}$ & $\mathbf{3}$ & $\mathbf{6}$ & $\mathbf{0}$ & $\mathbf{2 5}$ & $\mathbf{0}$ \\
\hline Sarpy & $\mathbf{3}$ & $\mathbf{2 3}$ & $\mathbf{1 2}$ & $\mathbf{1 1}$ & $\mathbf{1}$ & $\mathbf{5 0}$ & $\mathbf{1 1}$ \\
\hline Saunders & $\mathbf{3}$ & $\mathbf{1 4}$ & $\mathbf{9}$ & $\mathbf{8}$ & $\mathbf{1}$ & $\mathbf{3 5}$ & $\mathbf{1 2}$ \\
\hline Seward & $\mathbf{1}$ & $\mathbf{1 4}$ & $\mathbf{4}$ & $\mathbf{7}$ & $\mathbf{1}$ & $\mathbf{2 7}$ & $\mathbf{3}$ \\
\hline Rec. Co. Rec. & $\mathbf{3 7}$ & $\mathbf{2 2 6}$ & $\mathbf{8 3}$ & $\mathbf{1 2 3}$ & $\mathbf{1 8}$ & $\mathbf{4 8 9}$ & $\mathbf{1 3 7}$ \\
\hline & & & & & & & \\
\hline SOUTHWEST SP & $\mathbf{7}$ & $\mathbf{2 2}$ & $\mathbf{2 1}$ & $\mathbf{1 2}$ & $\mathbf{1 3}$ & $\mathbf{7 7}$ & $\mathbf{5 7}$ \\
\hline Arthur & $\mathbf{2}$ & $\mathbf{5}$ & $\mathbf{1 2}$ & $\mathbf{8}$ & $\mathbf{5}$ & $\mathbf{3 2}$ & $\mathbf{2}$ \\
\hline Chase & $\mathbf{3}$ & $\mathbf{1 1}$ & $\mathbf{7}$ & $\mathbf{7}$ & $\mathbf{4}$ & $\mathbf{3 2}$ & $\mathbf{9}$ \\
\hline Dundy & $\mathbf{3}$ & $\mathbf{1 1}$ & $\mathbf{6}$ & $\mathbf{1 0}$ & $\mathbf{7}$ & $\mathbf{3 7}$ & $\mathbf{1 8}$ \\
\hline Frontier & $\mathbf{3}$ & $\mathbf{1 2}$ & $\mathbf{4}$ & $\mathbf{7}$ & $\mathbf{4}$ & $\mathbf{3 0}$ & $\mathbf{0}$ \\
\hline Furnas & $\mathbf{2}$ & $\mathbf{1 3}$ & $\mathbf{3}$ & $\mathbf{7}$ & $\mathbf{3}$ & $\mathbf{2 8}$ & $\mathbf{2}$ \\
\hline Hayes & $\mathbf{3}$ & $\mathbf{1 1}$ & $\mathbf{6}$ & $\mathbf{8}$ & $\mathbf{4}$ & $\mathbf{3 2}$ & $\mathbf{0}$ \\
\hline Hitchcock & $\mathbf{2}$ & $\mathbf{1 4}$ & $\mathbf{5}$ & $\mathbf{8}$ & $\mathbf{2}$ & $\mathbf{3 2 d}$ & $\mathbf{0}$ \\
\hline Keith & $\mathbf{2}$ & $\mathbf{6}$ & $\mathbf{1 1}$ & $\mathbf{1 1}$ & $\mathbf{8}$ & $\mathbf{3 8}$ & $\mathbf{2 0}$ \\
\hline Lincoln & $\mathbf{1 7}$ & $\mathbf{1 9}$ & $\mathbf{1 1}$ & $\mathbf{8}$ & $\mathbf{6 1}$ & $\mathbf{4 7}$ \\
\hline Logan & $\mathbf{1}$ & $\mathbf{6}$ & $\mathbf{1 1}$ & $\mathbf{8}$ & $\mathbf{5}$ & $\mathbf{3 4 c}$ & $\mathbf{2 1}$ \\
\hline McPherson & $\mathbf{0}$ & $\mathbf{6}$ & $\mathbf{8}$ & $\mathbf{8}$ & $\mathbf{1}$ & $\mathbf{2 3}$ & $\mathbf{0}$ \\
\hline Perkins & $\mathbf{1}$ & $\mathbf{1 5}$ & $\mathbf{7}$ & $\mathbf{8}$ & $\mathbf{3}$ & $\mathbf{3 4}$ & $\mathbf{1 1}$ \\
\hline Red Willow & $\mathbf{1 3 4}$ & $\mathbf{1 1 2}$ & $\mathbf{1 0 9}$ & $\mathbf{5 8}$ & $\mathbf{4 4 3}$ & $\mathbf{1 3 1}$ \\
\hline Reg. Co. Rec. & & & & & \\
\hline & & & & & $\mathbf{3 2 9}$ & $\mathbf{3 1 0 3 a}$ & $\mathbf{8 3 1 b}$ \\
\hline NEBRASKA CR. & $\mathbf{1 7 5}$ & & & & \\
\hline
\end{tabular}

a - includes 3 tropical and 2 southwestern species records

b-includes 1 tropical and 1 southwestern species record

c-includes 1 tropical species

d - includes 1 southwestern species 


\section{APPENDIX G - COUNTY AREAS AND POPULATION DENSITIES}

\begin{tabular}{|c|c|c|c|c|}
\hline County & $\begin{array}{l}\text { Area in } \\
\text { square miles }\end{array}$ & $\begin{array}{l}\text { Population } \\
\text { In thousands }\end{array}$ & $\begin{array}{l}\text { Pop. density } \\
\text { per sq. mile }\end{array}$ & $\begin{array}{l}\text { Year of } \\
\text { Incorporation }\end{array}$ \\
\hline NORTHEAST & 10590 & 241.8 & 22.8 & \\
\hline Antelope & 860 & 6.4 & 7.4 & 1871 \\
\hline Boone & 690 & 5.4 & 7.8 & 1871 \\
\hline Boyd & 540 & 2.0 & 3.7 & 1891 \\
\hline Burt & 490 & 6.6 & 13.5 & 1854 \\
\hline Cedar & 740 & 8.7 & 11.8 & 1857 \\
\hline Colfax & 410 & 10.5 & 25.6 & 1869 \\
\hline Cuming & 570 & 9.1 & 16.0 & 1855 \\
\hline Dakota & 260 & 20.7 & 79.6 & 1855 \\
\hline Dixon & 480 & 5.8 & 12.1 & 1856 \\
\hline Dodge & 530 & 36.7 & 69.2 & 1854 \\
\hline Knox & 1110 & 8.6 & 7.7 & 1857 \\
\hline Madison & 570 & 35.1 & 61.6 & 1856 \\
\hline Nance & 440 & 3.6 & 8.2 & 1879 \\
\hline Pierce & 570 & 7.2 & 12.6 & 1856 \\
\hline Platte & 680 & 32.7 & 48.1 & 1856 \\
\hline Stanton & 430 & 6.0 & 14.0 & 1855 \\
\hline Thurston & 390 & 7.0 & 17.9 & 1889 \\
\hline Washington & 390 & 20.3 & 52.1 & 1854 \\
\hline Wayne & 440 & 9.4 & 21.4 & 1867 \\
\hline PANHANDLE & 14200 & 86.8 & 6.1 & \\
\hline Banner & 750 & 0.8 & 1.1 & 1888 \\
\hline Box Butte & 1080 & 11.3 & 10.5 & 1887 \\
\hline Cheyenne & 1200 & 10.1 & 8.4 & 1867 \\
\hline Dawes & 1400 & 9.1 & 6.5 & 1885 \\
\hline Deuel & 400 & 1.9 & 4.3 & 1888 \\
\hline Garden & 1710 & 1.9 & 1.1 & 1910 \\
\hline Kimball & 950 & 3.7 & 3.9 & 1888 \\
\hline Morrill & 1420 & 4.8 & 3.4 & 1908 \\
\hline Scotts Bluff & 740 & 36.6 & 49.5 & 1888 \\
\hline Sheridan & 2440 & 5.3 & 2.2 & 1885 \\
\hline Sioux & 2070 & 1.3 & 0.6 & 1877 \\
\hline NEBRASKA & 76920 & 1881.5 & 24.5 & 1867 \\
\hline
\end{tabular}


APPENDIX G - continued

\begin{tabular}{|c|c|c|c|c|}
\hline County & $\begin{array}{l}\text { Area in } \\
\text { square miles }\end{array}$ & $\begin{array}{l}\text { Population } \\
\text { in thousands }\end{array}$ & $\begin{array}{l}\text { Pop. density } \\
\text { per sq. mile }\end{array}$ & $\begin{array}{l}\text { Year of } \\
\text { incorporation }\end{array}$ \\
\hline SANDHILLS & 20870 & 54.1 & 2.6 & \\
\hline Blaine & 710 & 0.6 & 0.8 & 1885 \\
\hline Brown & 1220 & 3.0 & 2.5 & 1883 \\
\hline Cherry & 5960 & 5.8 & 1.0 & 1883 \\
\hline Custer & 2580 & 10.8 & 4.2 & 1877 \\
\hline Garfield & 570 & 2.0 & 3.5 & 1884 \\
\hline Grant & 780 & 0.6 & 0.8 & 1887 \\
\hline Greeley & 570 & 2.4 & 4.2 & 1871 \\
\hline Holt & 2410 & 10.4 & 4.3 & 1860 \\
\hline Hooker & 720 & 0.7 & 1.0 & 1889 \\
\hline Howard & 570 & 6.4 & 11.2 & 1871 \\
\hline Keya Paha & 770 & 0.7 & 0.9 & 1884 \\
\hline Loup & 570 & 0.5 & 0.9 & 1883 \\
\hline Rock & 1010 & 1.4 & 1.4 & 1885 \\
\hline Sherman & 570 & 3.1 & 5.4 & 1871 \\
\hline Thomas & 710 & 0.7 & 1.0 & 1887 \\
\hline Valley & 570 & 4.2 & 7.4 & 1871 \\
\hline Wheeler & 580 & 0.8 & 1.4 & 1877 \\
\hline $\begin{array}{l}\text { SOUTH } \\
\text { CENTRAL }\end{array}$ & 11250 & 257.8 & 22.9 & \\
\hline Adams & 560 & 31.5 & 56.3 & 1867 \\
\hline Buffalo & 970 & 48.4 & 49.9 & 1855 \\
\hline Clay & 570 & 6.3 & 11.1 & 1855 \\
\hline Dawson & 1010 & 23.9 & 23.7 & 1860 \\
\hline Fillmore & 580 & 5.7 & 9.8 & 1856 \\
\hline Franklin & 580 & 3.1 & 5.3 & 1867 \\
\hline Gosper & 460 & 2.0 & 4.3 & 1873 \\
\hline Hall & 550 & 61.1 & 11.1 & 1858 \\
\hline Hamilton & 540 & 9.1 & 16.9 & 1867 \\
\hline Harlan & 550 & 3.5 & 6.4 & 1871 \\
\hline Jefferson & 570 & 7.4 & 13.0 & 1856 \\
\hline Kearney & 520 & 6.5 & 12.5 & 1860 \\
\hline Merrick & 490 & 7.8 & 15.9 & 1858 \\
\hline Nuckolls & 580 & 4.4 & 7.6 & 1860 \\
\hline Phelps & 540 & 9.2 & 17.0 & 1873 \\
\hline Polk & 440 & 5.2 & 11.8 & 1856 \\
\hline Thayer & 580 & 5.2 & 9.0 & 1871 \\
\hline Webster & 580 & 3.7 & 6.4 & 1867 \\
\hline York & 580 & 13.8 & 23.8 & 1855 \\
\hline
\end{tabular}




\section{APPENDIX G - continued}

\begin{tabular}{|c|c|c|c|c|}
\hline County & $\begin{array}{l}\text { Area in } \\
\text { square miles }\end{array}$ & $\begin{array}{l}\text { Population in } \\
\text { thousands }\end{array}$ & $\begin{array}{l}\text { Pop. density } \\
\text { per sq. mile }\end{array}$ & $\begin{array}{l}\text { Year of } \\
\text { incorporation }\end{array}$ \\
\hline SOUTHEAST & 7710 & 1164.4 & 151.0 & \\
\hline Butler & 580 & 8.2 & 14.1 & 1856 \\
\hline Cass & 580 & 25.5 & 45.5 & 1854 \\
\hline Douglas & 330 & 543.3 & 1646.4 & 1854 \\
\hline Gage & 860 & 21.8 & 25.3 & 1855 \\
\hline Johnson & 380 & 5.2 & 13.7 & 1857 \\
\hline Lancaster & 840 & 301.7 & 359.2 & 1855 \\
\hline Nemaha & 410 & 7.1 & 17.3 & 1854 \\
\hline Otoe & 620 & 15.9 & 25.6 & 1854 \\
\hline Pawnee & 430 & 2.7 & 6.3 & 1855 \\
\hline Richardson & 550 & 8.1 & 14.7 & 1854 \\
\hline Saline & 580 & 14.4 & 24.8 & 1867 \\
\hline Sarpy & 240 & 172.5 & 718.8 & 1857 \\
\hline Saunders & 750 & 20.9 & 27.9 & 1856 \\
\hline Seward & 580 & 17.1 & 29.5 & 1855 \\
\hline SOUTHWEST & 12300 & 76.6 & 6.2 & \\
\hline Arthur & 720 & 0.4 & 0.6 & 1887 \\
\hline Chase & 890 & 4.1 & 4.6 & 1873 \\
\hline Dundy & 920 & 1.8 & 2.0 & 1873 \\
\hline Frontier & 980 & 2.6 & 2.7 & 1872 \\
\hline Furnas & 720 & 4.9 & 6.8 & 1873 \\
\hline Hayes & 710 & 1.0 & 1.4 & 1877 \\
\hline Hitchcock & 710 & 2.9 & 4.1 & 1873 \\
\hline Keith & 1060 & 8.1 & 7.6 & 1873 \\
\hline Lincoln & 2560 & 35.8 & 14.0 & 1860 \\
\hline Logan & 570 & 0.8 & 1.4 & 1885 \\
\hline McPherson & 860 & 0.2 & 0.5 & 1887 \\
\hline Perkins & 880 & 2.9 & 3.3 & 1887 \\
\hline Red Willow & 720 & 10.9 & 15.1 & 1873 \\
\hline NEBRASKA & 76920 & 1881.5 & 24.5 & 1867 \\
\hline
\end{tabular}

Year and Area: https://en.wikipedia.org/wiki/list_of_counties_in_Nebraska

Population: https://factfinder.census.gov/faces/nav/jsf/pages/community facts.xhtml\# https://factfinder.census.gov/faces/tableservices/jsf/pages/productview.xhtml?src=bkmk 

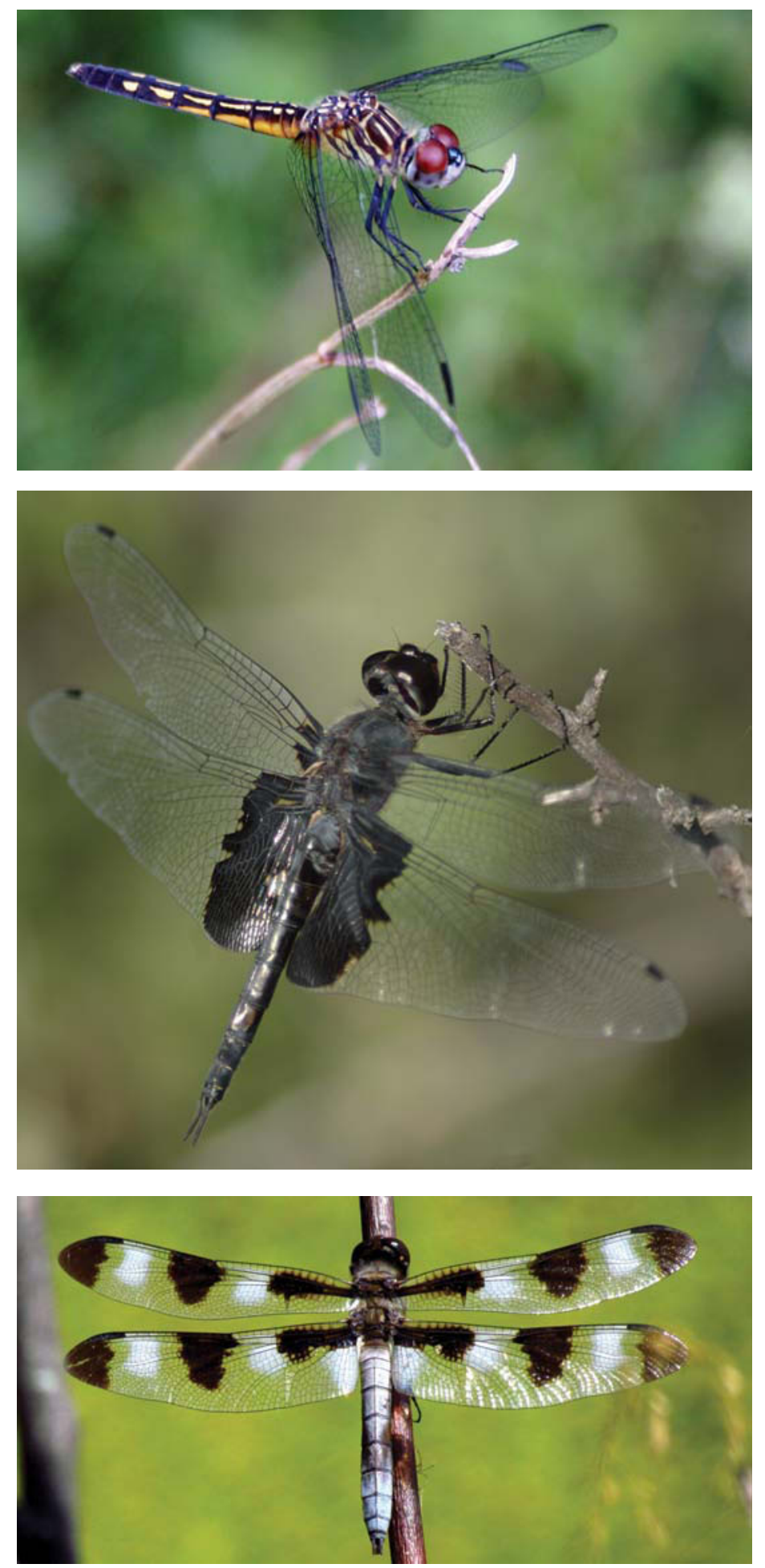

Above (top to bottom):

Pachydiplax longipennis (Blue Dasher), female, R. A. Nonenmacher CC-BY-SA Tramea lacerata (Black Saddlebags), Jerry Friedman CC-BY-SA

Libellula pulchella (Twelve spotted skimmer), D. Gordon E. Robertson CC-BY-SA

\section{Right (top to bottom):}

Hetaerina americana (American Rubyspot), photo Bruce Marlin, CC-BY-SA Calopteryx maculata (Ebony Jewelwing), male, D. Gordon E. Robertson CC-BY-SA Argia nahuana (Aztec Dancer), Richard Murphy CC-BY-SA
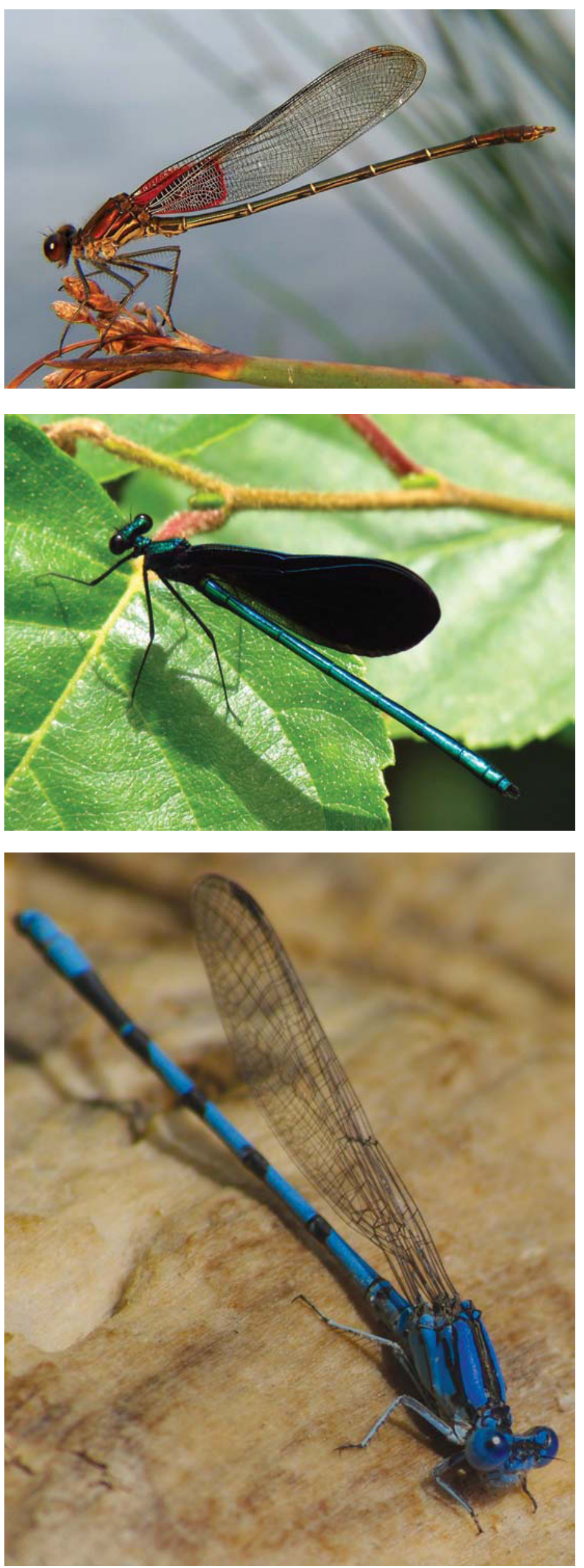
